\title{
COMBINED LAND USE OF SOLAR INFRASTRUCTURE AND AGRICULTURE FOR SOCIOECONOMIC AND ENVIRONMENTAL CO-BENEFITS IN THE TROPICS
}

\author{
A Thesis \\ Submitted to the \\ Temple University Graduate Board
}

In Partial Fulfillment

Of the Requirement for the Degree

MASTER OF SCIENCE

GEOLOGY

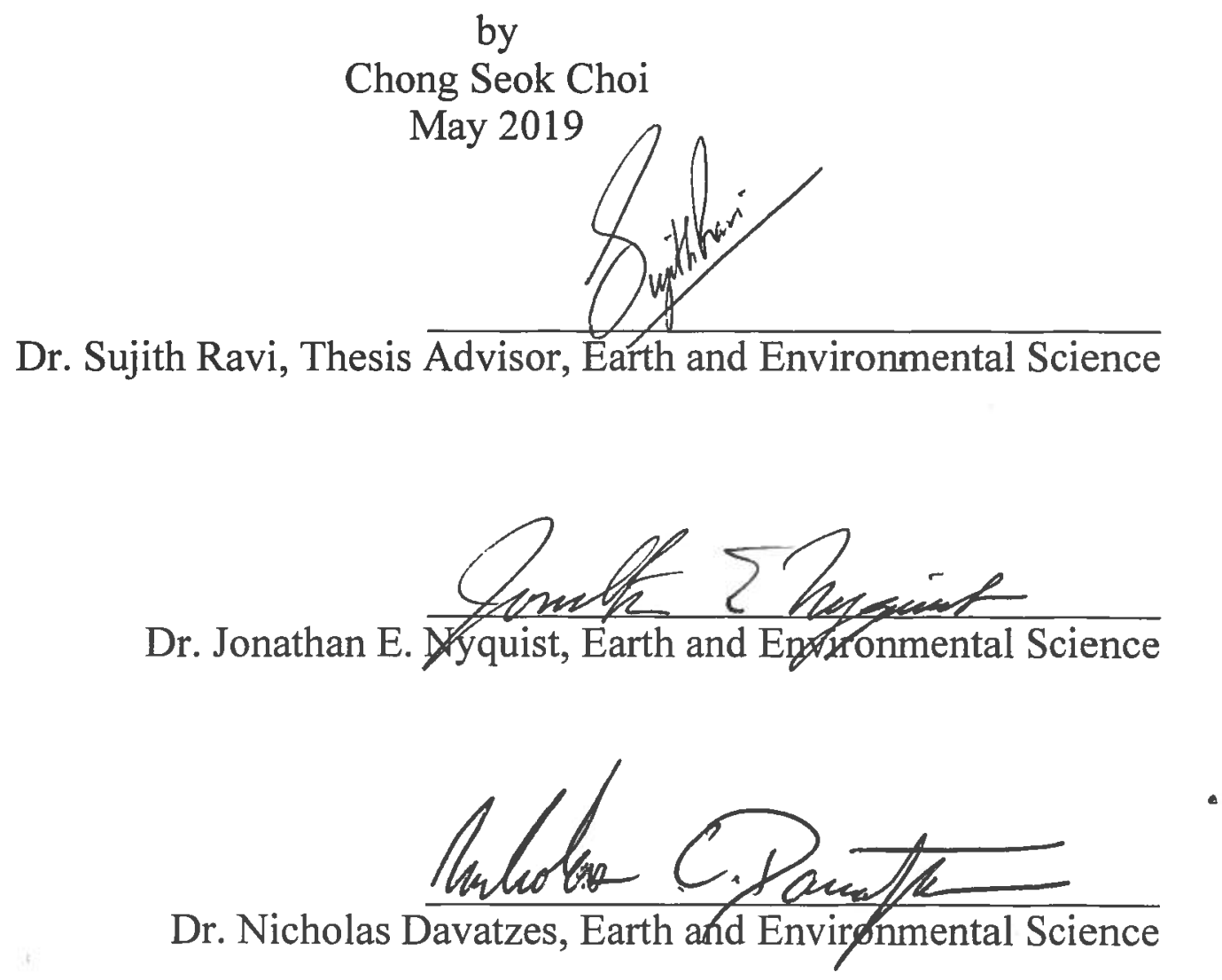




\begin{abstract}
Solar photovoltaic (PV) generation has been gaining popularity as low carbon energy technology in the face of the global climate change. However, conventional utilityscale PV requires large swaths of land to be occupied for decades which prevents the land from producing food or performing vital ecosystem services. Co-location of PV with crop cultivation is an emerging strategy for mitigating the land use of PV. In order to optimize this strategy, the impact of the plant growth-related soil properties need to be quantified. To this end, the first portion of the thesis investigated the impacts on the soil properties in a re-vegetated solar PV facility in Boulder, Colorado, which was the oldest vegetation-PV co-location site in the world. The second portion of the thesis uses a life cycle analysis (LCA) approach to test the feasibility of co-location of model crop cultivation and solar PV electricity generation in rural Indonesia, and it is the first study to use the LCA study of the co-located solar in the tropics.

The first approach revealed that the soil hydrology, grain size distribution, and total carbon and nitrogen are significantly altered from their original state by the construction and presence of photovoltaic arrays, and that those properties had not been restored to their pre-construction levels despite the fact that ten years had passed since re-vegetation of the PV array. The persistence of the altered soil properties meant that the designs regarding revegetation or co-location of PV with crops would have to be considered at the beginning of the construction of the PV to minimize the impact on the soil and the existing vegetation. Furthermore, soil moisture was the highest in the soil underneath the western edge of the PV panels, where the western tilt of the PV panel had concentrated the rainfall. The heterogeneity in soil hydrology created by the panels could be manipulated to benefit the growth of vegetation within the PV array.
\end{abstract}


The LCA approach revealed that a hectare of PV arrays with full module density would carbon offsets against diesel electricity generation and the grid, and that the annual supply of electricity from the PV could satisfy the demand of a typical rural Indonesian village several times over. However, the high capital expenditure of solar mean that colocation with full PV module density would not be economically feasible, even with the income stream from the co-located crop cultivation. In order to reduce the capital expenditure, the PV module density for co-location was reduced to half. The combination of reduced capital expenditure and the income stream from the crop made the co-located land use significantly less costly. Additionally, the rural electrification would be able to provide secondary socioeconomic benefits such as avoidance of health costs through operation of public health infrastructures, increased standard of living, and secondary income opportunities from processing of raw materials. However, better subsidies for renewables, specialized loan structures for small-scale renewable systems, and a culture of co-operation between small landholders would need to be implemented before the colocated system becomes affordable to the inhabitants in rural Indonesian villages. 


\section{ACKNOWLEDGMENTS}

This research was funded by Department of Energy's Sunshot fund.

I would like to thank my collaborator Jordan Macknick at National Renewable Energy Laboratory, whose support at different junctures of my master's program made this research possible.

I'm grateful to Dr. Iskandar Z Siregar and Dr. Fifi Gus Dwiyanti of Bogor Agricultural University. Their boundless hospitality and guidance during my field work in Indonesia made a large portion of my research possible.

I would be nowhere without Shelah Cox, who is an overall amazing person without whom I could not have stayed sane.

My deepest gratitude goes to everyone with whom I have had the pleasure to work. Each members of my thesis committee provided me with extensive personal and professional guidance. Of course, none of this would have been possible without my advisor and role model Dr. Sujith Ravi. The insights he shared with me in the field and in the lab was crucial in the development of this thesis, and in my overall growth as a scientist and a person. He taught me way more than I could give him credit for on this page.

I would like to offer my sincerest thanks to my family, including my new brotherin-law, whose endless love and support were continually felt across the sea. I would have had neither the courage nor the strength pursue this endeavor if it weren't for you. I love you and miss you always.

Finally, my deep gratitude goes to Gabi, who was always a willing audience for my expository writing and figures. 


\section{TABLE OF CONTENTS}

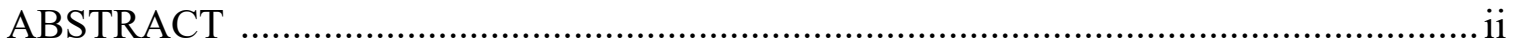

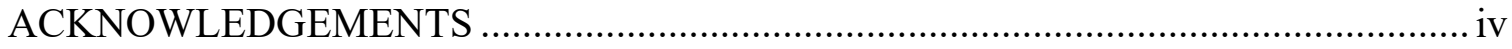

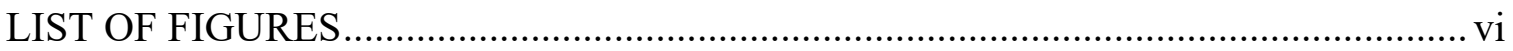

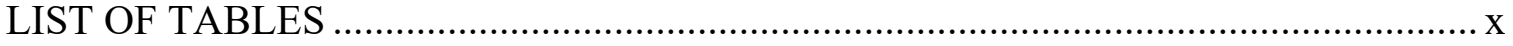

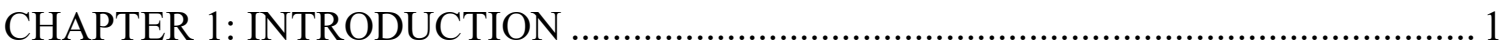

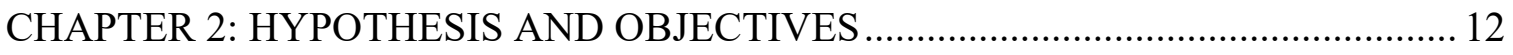

CHAPTER 3: IMPACTS OF SOLAR

PHOTOVOLTAIC ARRAYS ON THE SOIL

PHYSICOCHEMICAL PROPERTIES: A

PRELIMINARY INVESTIGATION ON A SOLAR

PV TEST SITE IN COLORADO, USA …................................................................ 15

CHAPTER 4: COMBINED LAND USE OF

SOLAR INFRASTRUCTURE AND

AGRICULTURE FOR SOCIOECONOMIC AND

ENVIRONMENTAL CO-BENEFITS IN

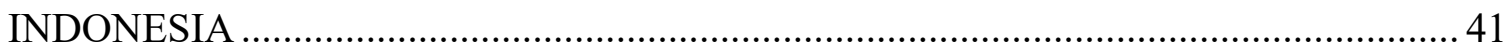

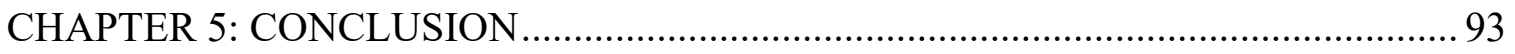

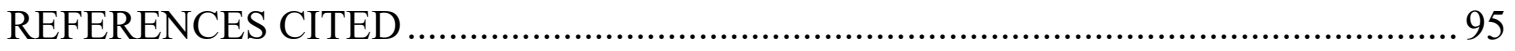

APPENDICES

A. THE INPUT SCRIPT FOR THE LCA MODELS

B. THE LIFE CYCLE ANALYSIS MODEL OF

SOLAR PV LAND USE

C. THE LIFE CYCLE ANALYSIS MODEL OF

PATCHOULI CULTIVATION AND

DISTILLATION LAND USE.

D. THE LIFE CYCLE ANALYSIS MODEL OF

CO-LOCATED PV-PATCHOULI CO-LOCATION 


\section{LIST OF FIGURES}

Figure 1-1. Historical levelized cost of energy (LCOE) of solar photovoltaics (PV). Data from OpenEI [17]

Figure 1-2. Indonesia's electrification rates in 2013, modified from International Energy Agency [11]. The red square represents the study area in West Java. The gray shading indicates neighboring nations.

Figure 3-1. (a) A satellite image obtained from

Google Maps shows the location of the treatment transects and the control transect near the northeastern corner of the photovoltaic facility at the NWTC. The treatment transects $\mathrm{T} 1$ to $\mathrm{T} 3$ are located in the revegetation study area, and the control transect T4 is located in an undisturbed area adjacent to the PV array. Measuring and sampling locations are determined as a function of their position relative to the photovoltaic array (b). Both edge locations are approximate, as the exact location of the edges along the horizontal transect varies with the daily swivel of the tracking array (b). Each symbol of a photovoltaic module represents a row of module (c). A transect encompasses four rows of PV modules and their relative positions along the horizontal transect (c). Figures $\mathbf{b}$ and $\mathbf{c}$ are not to scale.

Figure 3-2. Average wind direction at 2-meters from the ground and accumulated precipitation during the precipitation event on July $25^{\text {th }}, 2017$. Average wind direction and standard deviation are shown in bright orange and faded orange, respectively, and the accumulated precipitation is shown in blue.

Figure 3-3. (a) Soil moisture before and after the precipitation event of the control transect ("C" and "C-Rain") is compared to soil moisture before and after the precipitation event of the treatment transect T1 ("T" and "T-rain"). For the control plot, there were 32 measurements before and after the rain event, and there were 64 measurements before and after the rain event for the treatment. (b) Soil moisture before and 
after the precipitation event of the control transect T4 ("C") is compared to that of the relative positions ("CS," "EE," "IS," and "WE") of the treatment transects. The middle notch denotes the median, the lower and the upper hinges correspond to the first and third quartiles, and the whiskers extend to 1.5 interquartile range above and below the median. As in (b), the control has 32 measurements before and after the rain, but each relative position has 16 measurements before and after the rain.

Figure 3-4. (a) Comparison of mean unsaturated hydraulic conductivity between the control ("C") and the treatment ("T") before the precipitation event. There are 32 measurements in the control and 64 in the treatment. (b) Comparison of mean unsaturated hydraulic conductivity between the control (" $\mathrm{C}$ ") and the relative positions in the treatment ("T") before the precipitation event. The control has 32 measurements, and each relative position has 16 . For both figures, the middle notch denotes the median, the lower and the upper hinges correspond to the first and third quartiles, and the whiskers extend to 1.5 interquartile range above and below the median.

Figure 3-5. (a,b) Total carbon and total nitrogen of the control transect ("C") are compared to those of the treatment transects T1-4 ("T"). (c,d) Total carbon and total nitrogen of the control transect ("C") are compared to those of the relative positions ("CS," "EE," "IS," and "WE") of the treatment transects T1-4. The middle notch denotes the median, the lower and the upper hinges correspond to the first and third quartiles, and the whiskers extend to 1.5 interquartile range above and below the median. There are 16 measurements for the control and 64 for the treatment.

Figure 3-6. Comparison of mean $\mathrm{CN}$ ratio between the control (" $\mathrm{C}$ ") and the relative positions within the treatment ("T"). The middle notch denotes the median, the lower and the upper hinges correspond to the first and third quartiles, and the whiskers extend to 1.5 interquartile range above and below the median. 
There are 16 measurements for the control and 64 for the treatment.

Figure 3-7. (a) Comparison of median and mean particle size in the soil samples from control and treatment transects. The middle notch denotes the median, the lower and the upper hinges correspond to the first and third quartiles, and the whiskers extend to 1.5 interquartile range above and below the median. (b) Sorting is plotted against the mean particle size on Krumbein phi scale for control and treatment groups ("C" and "T", respectively). There are 16 measurements for the control and 64 for the treatment.

Figure 3-8. Mass fraction comparison of soil sample whose grain diameter is larger than 2 $\mathrm{mm}$ (lower threshold for pebble classification) by experimental group and relative positions. The middle notch denotes the median, the lower and the upper hinges correspond to the first and third quartiles, and the whiskers extend to 1.5 interquartile range above and below the median. There are 16 measurements for the control and 64 for the treatment.

Figure 3-9. Simplified representation of the mechanism behind the rainfall concentration and elevation of soil moisture in the WE.

Figure 4-1. A schematic diagram summarizing the methodology of this study. The LCA model is highlighted in green, and the outputs of the sensitivity analysis and the Monte Carlo simulation is highlighted in blue.

Figure 4-2. Energy inputs and outputs from standalone solar PV land use, co-located land use with $400 \mathrm{kWp} \mathrm{ha}^{-1}$ module density, colocated land use with $200 \mathrm{kWp} \mathrm{ha-1}$ module density; and energy input for patchouli cultivation and distillation. The yellow bars represent the energy produced by the PV component of the respective land uses (in parentheses), and the gray bars represent the energy requirement for each land uses. The error bars represent the $10^{\text {th }}$ and the $90^{\text {th }}$ percentile of the frequency distribution. 
Figure 4-3. GHG emissions and offsets from standalone solar PV land use, co-located land use with $400 \mathrm{kWp} \mathrm{ha}^{-1}$ module density, colocated land use with $200 \mathrm{kWp} \mathrm{ha}{ }^{-1}$ module density; and GHG emissions for patchouli cultivation and distillation. The green bars represent the GHG gas offsets against diesel or grid by the PV component of the respective land uses (in parentheses), and the orange bars represent the GHG emissions from the respective land uses. The error bars represent the $10^{\text {th }}$ and the $90^{\text {th }}$ percentile of the frequency distribution.

Figure 4-4. Net present value (NPV) frequency distributions from Monte Carlo analysis ( $\mathrm{n}=$ 10,000) where the $\mathrm{x}$-axis represents NPV in Indonesian Rupiah (IDR). The red, dotted line at the center of each curve represents the mean NPV.

Figure 4-5. Sankey diagram showing the energy input into the standalone land use and the flow of the electricity output into different components of the energy demand of a model village from [12].

Figure 4-6. Comparison of capital expenditure (CAPEX) and levelized cost of energy (LCOE) among renewable sources in the US. Data from [115]. Diesel costs in Indonesia from [116]. Comparison of capital expenditure (CAPEX) and levelized cost of energy (LCOE) among renewable sources in the US. Data from [115]. Diesel costs in Indonesia from [116]. 


\section{LIST OF TABLES}

Table 1-1: Global horizontal irradiation in eight locations in Indonesia. Data from World Bank Group [20].

Table 4-1. Assumptions made for the LCA of standalone solar photovoltaics

Table 4-2. Assumptions made for the inputs for the LCA of patchouli cultivation and distillation

Table 4-3. Fertilizer application schedule

Table 4-4. Assumptions made for the economic analysis of standalone $\mathrm{PV}$, patchouli cultivation and distillation, and co-located land uses.

Table 4-5. Results of the sensitivity analysis (energy input).

Table 4-6. Results of the sensitivity analysis (GHG emissions)

Table 4-7. Tabulated results of the Monte Carlo simulation of the LCA of the energy inputs/outputs and GHG emissions/offsets of the land uses. $10^{\text {th }}$ and $90^{\text {th }}$ percentiles in parentheses. 


\section{CHAPTER 1}

\section{INTRODUCTION}

As global population grows, so does the demand for energy to sustain socioeconomic development and human welfare [1]. To meet this ever increasing demand, global annual total primary energy supply (TPES), the sum of energy contained in raw fuels, has increased from 6,101 million tons of oil equivalent (Mtoe) to 13,699 Mtoe between 1973 and 2014 [2]. In 2014, fossil fuels accounted for the 59.9\% of the global annual TPES [2]. This trend comes as no surprise as fossil fuels have been contributing the majority of the global energy supply since as early as the 1850s [1]. However, the increase in greenhouse gases (GHG) (mainly carbon dioxide) emissions from fossil fuels is a cause for alarm as it has been identified as the dominant cause of the global climate change $[1,3,4]$. The growth in global energy demands accompanying burgeoning populations and economic expansions in many large developing nations such as China, India, and Indonesia will likely magnify the environmental problems associated with GHG emissions from fossil fuels: the global primary energy demand in 2013 was 530 exajoules (EJ) $\mathrm{yr}^{-1}$, and it has been forecasted at 790-2050 $\mathrm{EJ} \mathrm{yr}^{-1}$ for 2100 in a business-as-usual scenario [5].

One of the most promising options for lowering GHG emissions is to transition to renewable energies $[1,3,5]$. The Intergovernmental Panel on Climate Change (IPCC) has estimated the sum of technical potential of renewable energies to far exceed the current primary energy and electricity demands and far exceed future energy demands, which may hike to $325 \mathrm{EJ} \mathrm{yr}^{-1}$ by the year 2050 and to $2050 \mathrm{EJ} \mathrm{yr}^{-1}$ by the year 2100 [1,6]. Even though low carbon emission technologies such as solar energy may provide pathways for sustainable energy production to meet the current and future energy requirements, 
deploying large-scale solar infrastructure on such a large scale has socioeconomic constraints and may even negatively impact land and water resources in some regions $[7,8]$.

The problems caused by increasing energy demand and their solutions can be scaled down and examined at a national scale. Case in point is Indonesia, an emerging economy with the world's fourth largest population (264 million in 2017) and rapidly expanding energy consumption $[9,10]$. As a result of the expanding demand, Indonesia is prompted to resolve the multidimensional problems of its growing energy sector. These problems include a large portion of the population (approximately 20\%) that still lacks access to electricity [11], primary dependence on fossil fuels (45\%), increasing dependence on imported oil [11,12], and the need to dissociate economic growth with greenhouse gas emissions in the face of climate change [12]. Adding to these problems is the archipelagic geography of Indonesia that renders most of the country's non-electrified regions too remote and costly to electrify by extension of established electrical grids [12]. This set of problems presents a unique opportunity to use off-grid solar photovoltaic (PV) systems as an alternative to diesel, which is commonly used as a means of on-site generation in nonelectrified rural areas [12]. Electrification of rural villages via solar PV can provide a foundation upon which rural economies can grow without incurring additional GHG emissions [12].

The feasibility and the benefits of solar PV-based, rural village grids are contingent on the profitability of such grids. Unfortunately, to date solar PV has been cost-prohibitive, and its power output fluctuates with weather, limiting the types of economic activities that it can support [13]. Additionally, deploying utility-scale solar PV infrastructure may have negative impacts, such as the tendency to convert arable lands to photovoltaics or water consumption during their maintenance [7,14]. However, the combination of recent rapid 
reductions in levelized cost of electricity (LCOE) - defined as lifetime cost of electricity generation divided by electricity produced by the technology over its lifetime (Fig. 1-1) combined with strategies to mitigate negative impacts may render solar PV an attractive option even in areas of low insolation.

An emerging option being evaluated for arid and semi-arid regions is the colocation of solar PV installations with carefully selected agricultural crops or biofuels [1416]. Strategies such as solar-crop colocation have the potential to abate the cost of solar power generation in an off-grid scenario and also offer several co-benefits including local economic stimulus through employment generation, rural electrification in remote areas, and renewable electricity sources for processing agricultural products locally [14], and further mitigates concerns related to loss of arable land or of scarce water resources. This study aimed to determine the expected and unexpected environmental and socioeconomic benefits from a co-location of solar PV and crop cultivation for a tropical climate such as that of Indonesia.

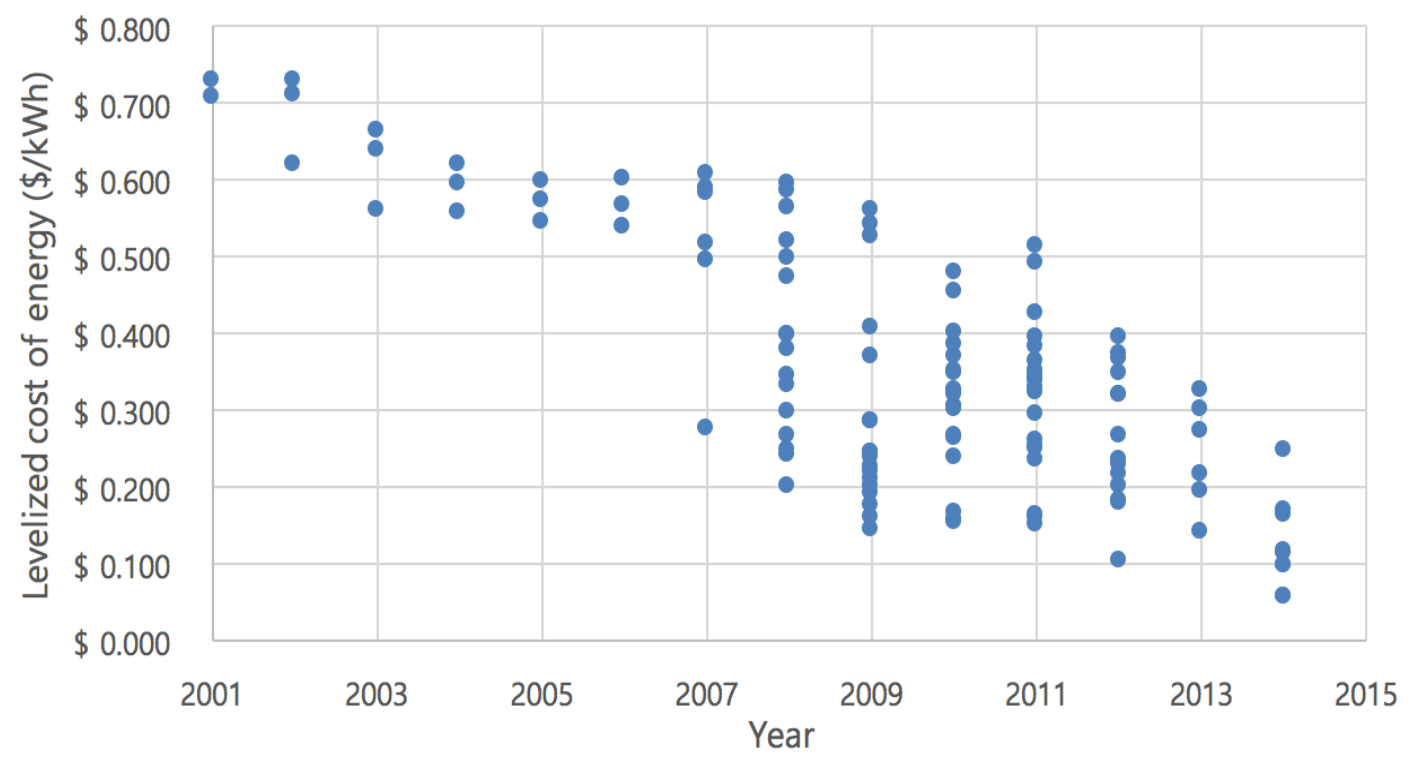

Figure 1-1. Historical levelized cost of energy (LCOE) of solar photovoltaics (PV). Data from OpenEI [17] 
Two studies are conducted: (1) a preliminary study of co-location in the relatively arid Colorado climate which builds a framework for analyzing the impact of photovoltaics on soils, soil performance, and water use that builds upon prior arid-climate work; (2) a study of co-location in the tropical climate of Indonesia, where land rather than water is the scarce and limiting commodity.

The study of co-location in tropical climates breaks new ground in this field and is the primary focus of this study, whereas the work in Colorado provides a useful benchmark of methodologies for comparison with the well-established arid-climate work.

\subsection{Indonesia’s Geography and Climate}

Indonesia is located in Southeastern Asia, between the Indian ocean and the Pacific ocean [18]. It lies on the equator and has a tropical climate [19]. The average temperature from 1992 to 2012 was $26.2^{\circ} \mathrm{C}$ [20], and the average daily insolation ranges from 4.5 to $5.1 \mathrm{kWh} / \mathrm{m}^{2}$ [21], which is equivalent to an average annual insolation range of 1600 to $1900 \mathrm{kWhm}^{-2}$. The dry season is from August to November, while the rainy season is from December to February [22]. Daily averages, average minima, and average maxima of global horizontal irradiation is shown by month of the year in Table 1-1.

As an archipelago of 13,466 islands, Indonesia is the world's largest country comprised entirely of islands that house the fourth largest population in the world at approximately 258 million [18]. Its total land area is $1,811,569 \mathrm{~km}^{2}$, which is $15^{\text {th }}$ largest in the world. However, land area is also relatively limited as $51.7 \%$ of the land is forested 
and $31.2 \%$ is agricultural [18]. Only 922 of the 13,466 islands are permanently inhabited [18].

Indonesia is highly vulnerable to the effects of climate change because it has an extensive coastline that houses most of the population and economic activity, and much of its economy depends on natural resources sensitive to climate such as agriculture [11,23]. The estimated quarter of the population who live under or near the poverty line are especially susceptible to the harsher impacts of the climate change [21]. In addition to this climate sensitivity, rural electrification is difficult because of the physical barriers isolating rural communities from population centers and limited land. Consequently, viable power generation requires scalable, local methods with minimal or negative carbon impact.

\subsection{Indonesia's Energy Sector, and Difficulties in Developing Renewable Energies}

Indonesia's total primary energy demand in 2013 was approximately 164 million tons of oil equivalent (Mtoe), and total primary energy supply (TPES) in the same year was approximately 235 Mtoe [21]. Almost all of the TPES was generated by fossil fuels (95.24\%), and less than 5\% of the total primary energy supply was from renewable energy: hydropower (3.21\%), geothermal power (1.15\%), and biofuel $(0.40 \%)$ [21].

Indonesia's energy demand is estimated to rise between 7 and $10 \%$ every year [12,21], and electricity demand alone is estimated to triple between 2010 and 2030 [21]. In an effort to diversify fuel sources, improve environmental sustainability, and maximize the usage of domestic energy resources, the Indonesian government aims increase the share of new and renewable energy (NRE) to $23 \%$ of the total primary energy supply of 380 Mtoe by 2025 [21]. However, a slower transition from the fossil fuel is anticipated [21]. 
Table 1-1: Global horizontal irradiation in eight locations in Indonesia. Data from World Bank Group [20].

\section{Global Horizontal Irradiation $\left[\mathrm{kWh} / \mathrm{m}^{2}\right]$}

\begin{tabular}{|c|c|c|c|c|c|c|c|c|}
\hline \multirow{3}{*}{ Month } & \multicolumn{2}{|c|}{ Binjai } & \multicolumn{2}{|c|}{ Jambi } & \multicolumn{2}{|c|}{ Jakarta } & \multicolumn{2}{|c|}{ Pontianak } \\
\hline & \multirow{2}{*}{ Avg. } & \multirow{2}{*}{$\begin{array}{l}\text { Min } \\
\text { Max }\end{array}$} & \multirow{2}{*}{ Avg. } & \multirow{2}{*}{$\begin{array}{l}\text { Min } \\
\text { Max }\end{array}$} & \multirow{2}{*}{ Avg. } & Min & \multirow{2}{*}{ Avg. } & \multirow{2}{*}{$\begin{array}{l}\text { Min } \\
\text { Max }\end{array}$} \\
\hline & & & & & & Max & & \\
\hline \multirow{2}{*}{ Jan. } & \multirow{2}{*}{4.24} & 3.82 & \multirow{2}{*}{4.03} & 3.61 & \multirow{2}{*}{3.94} & 3.32 & \multirow{2}{*}{4.51} & 3.95 \\
\hline & & 4.60 & & 4.57 & & 5.02 & & 5.40 \\
\hline \multirow{2}{*}{ Feb. } & \multirow{2}{*}{4.70} & 4.13 & \multirow{2}{*}{4.46} & 4.07 & \multirow{2}{*}{3.90} & 2.97 & \multirow{2}{*}{4.83} & 3.94 \\
\hline & & 5.32 & & 4.79 & & 4.68 & & 5.37 \\
\hline \multirow{2}{*}{ Mar. } & \multirow{2}{*}{5.29} & 4.46 & \multirow{2}{*}{4.79} & 4.53 & \multirow{2}{*}{4.69} & 4.34 & \multirow{2}{*}{4.99} & 4.26 \\
\hline & & 5.73 & & 5.32 & & 5.71 & & 5.52 \\
\hline \multirow{2}{*}{ Apr. } & \multirow{2}{*}{4.98} & 4.52 & \multirow{2}{*}{4.60} & 3.98 & 471 & 4.37 & 498 & 4.72 \\
\hline & & 5.30 & & 4.95 & & 5.24 & & 5.25 \\
\hline Mav & 4.86 & 4.16 & 453 & 4.16 & 463 & 4.07 & 402 & 4.74 \\
\hline & & 5.31 & & 4.78 & & 5.24 & 4.92 & 5.31 \\
\hline Jun & 481 & 4.30 & 444 & 4.04 & 447 & 3.84 & 485 & 4.60 \\
\hline . & 4.01 & 5.23 & 4.44 & 5.02 & 4.47 & 4.98 & 4.05 & 5.10 \\
\hline Jul & 474 & 4.15 & 442 & 3.94 & 474 & 3.63 & 493 & 4.47 \\
\hline & & 5.18 & & 4.90 & & 5.42 & & 5.37 \\
\hline Aug & 4.75 & 4.17 & 4.60 & 4.04 & 528 & 4.55 & 402 & 4.44 \\
\hline & & 5.28 & & 4.93 & & 5.64 & 4.92 & 5.22 \\
\hline Sep. & 4.82 & 4.39 & 4.73 & 3.73 & 5.60 & 4.39 & 4.97 & 4.38 \\
\hline & & 5.56 & & 5.30 & & 5.64 & & 5.42 \\
\hline Oct. & 4.52 & 4.05 & 435 & 2.58 & 521 & 4.15 & 454 & 4.19 \\
\hline & & 5.01 & & 4.76 & & 6.15 & & 4.86 \\
\hline Noy & 422 & 3.72 & 429 & 3.93 & 463 & 4.19 & 428 & 3.46 \\
\hline 100. & 7.22 & 4.54 & T.2 & 4.55 & 7.00 & 5.16 & 4.20 & 4.63 \\
\hline Dec & 388 & 3.39 & 400 & 3.63 & 4.17 & 3.41 & 421 & 3.76 \\
\hline & & 4.36 & & 4.33 & & 4.56 & & 4.94 \\
\hline & 465 & 4.54 & 4.44 & 4.27 & 4.67 & 4.39 & 4.74 & 4.61 \\
\hline & & 4.74 & & 4.55 & & 5.02 & & 4.86 \\
\hline
\end{tabular}


Table 1-1: (continued)

\begin{tabular}{|c|c|c|c|c|c|c|c|c|c|}
\hline \multirow{4}{*}{ Month } & \multicolumn{8}{|c|}{ Global Horizontal Irradiation $\left[\mathrm{kWh} / \mathrm{m}^{2}\right]$} & \multirow{4}{*}{$\begin{array}{c}\text { Variability } \\
\text { between } \\
\text { sites }(\%)\end{array}$} \\
\hline & \multicolumn{2}{|c|}{ Surabaya } & \multicolumn{2}{|c|}{ Kupang } & \multicolumn{2}{|c|}{ Manado } & \multicolumn{2}{|c|}{ Jayapura } & \\
\hline & \multirow[t]{2}{*}{ Avg. } & Min & \multirow[t]{2}{*}{ Avg. } & Min & \multirow[t]{2}{*}{ Avg. } & Min & \multirow[t]{2}{*}{ Avg. } & Min & \\
\hline & & Max & & & & & & & \\
\hline \multirow{2}{*}{ Jan. } & \multirow{2}{*}{4.78} & 4.10 & \multirow{2}{*}{5.07} & 3.97 & \multirow{2}{*}{4.29} & 3.90 & \multirow{2}{*}{4.71} & 3.96 & \multirow{2}{*}{8.7} \\
\hline & & 5.55 & & 6.46 & & 4.83 & & 5.60 & \\
\hline \multirow{2}{*}{ Feb. } & \multirow{2}{*}{4.73} & 4.02 & \multirow{2}{*}{5.43} & 4.24 & \multirow{2}{*}{4.84} & 4.41 & \multirow{2}{*}{5.01} & 4.23 & \multirow{2}{*}{9.3} \\
\hline & & 5.41 & & 6.36 & & 5.71 & & 5.49 & \\
\hline \multirow{2}{*}{ Mar. } & \multirow{2}{*}{4.94} & 4.16 & \multirow{2}{*}{5.58} & 4.39 & \multirow{2}{*}{5.31} & 4.11 & \multirow{2}{*}{4.66} & 3.87 & \\
\hline & & 5.63 & & 6.41 & & 6.11 & & 5.85 & \\
\hline Anr & 4.82 & 4.32 & 5.92 & 5.01 & 515 & 4.20 & 504 & 4.58 & 80 \\
\hline Apr. & 4.82 & 5.27 & 5.92 & 6.47 & 5.15 & 6.13 & & 5.50 & \\
\hline Mav & 489 & 3.96 & 532 & 4.60 & 485 & 4.39 & 460 & 4.33 & 50 \\
\hline IViay & & 5.66 & & 5.85 & & 5.51 & 4.07 & 4.95 & 0.0 \\
\hline Jun. & 4.92 & 3.77 & 5.16 & 4.52 & 4.60 & 3.88 & 4.42 & 4.01 & 57 \\
\hline & 4.52 & 5.48 & 0.10 & 5.62 & 4.00 & 4.99 & 4.42 & 5.10 & \\
\hline $\mathrm{Jyl}$ & 538 & 4.64 & 545 & 4.82 & 488 & 4.25 & 436 & 3.84 & 81 \\
\hline Jur. & & 5.86 & & 5.79 & & 6.02 & 7.00 & 5.13 & 0.1 \\
\hline A & 616 & 5.45 & 623 & 5.79 & 543 & 4.84 & 490 & 4.31 & 118 \\
\hline Aug. & 0.10 & 6.50 & 0.25 & 6.56 & 5.45 & 6.53 & 4.90 & 5.69 & 11.8 \\
\hline Sen & 666 & 4.89 & 683 & 5.86 & 560 & 4.99 & 402 & 4.43 & 150 \\
\hline sеp. & 0.00 & 7.18 & 0.05 & 7.40 & 5.07 & 6.86 & 4.52 & 5.43 & \\
\hline Oct. & 647 & 4.91 & 7.07 & 6.14 & 5,44 & 4.80 & 525 & 4.51 & 18.1 \\
\hline & & 7.36 & & 7.77 & 3.44 & 6.57 & 0.20 & 5.85 & 10.1 \\
\hline Nov. & 5.32 & 4.50 & 6.52 & 5.64 & 4.66 & 4.25 & 4.99 & 4.40 & 158 \\
\hline & & 6.47 & & 7.13 & & 4.98 & & 5.69 & \\
\hline Dec & 4.40 & 3.86 & 5.08 & 4.21 & 4.53 & 4.17 & 488 & 4.46 & 95 \\
\hline & & 5.27 & & 5.60 & & 5.06 & 4.00 & 5.51 & 9.0 \\
\hline YEAR & 529 & 4.81 & 580 & 5.44 & 497 & 4.65 & 482 & 4.56 & 89 \\
\hline & & 5.73 & & 6.13 & & 5.60 & & 5.12 & \\
\hline
\end{tabular}


The national electrification ratio rose from $65 \%$ in 2008 to $80.51 \%$ in 2013 [11]. The electrification ratios are the highest within the Java-Bali system, with Jakarta achieving nearly $100 \%$ electrification [11]. The electrification ratio is the lowest in the outer ring of islands [11]. For instance, Papua's electrification ratio in 2013 was a mere $36 \%$ [11].

The challenges in providing electricity for this portion of the population are multifaceted. First, the areas with low electrification rate are off-grid and positioned far from most conventional and renewable fuel sources [11,24]. Second, low population density and low average consumption in these areas make cost recovery and adequate economies of scale difficult to achieve for investment in grid extension and connection infrastructure [11]. Third, even if the cost of grid extension and connection infrastructure were affordable, a large portion of PLN's budget is dedicated to alleviating the pressure from the aging of the existing infrastructure [12]. As a result, PLN's effort to increase the rural electrification ratio has been limited to off-grid solutions, such as small-scale dieselpowered generation $[11,12]$. While the government has stipulated that they would meet the electrification ratio of $89.56 \%$ by 2017 [21], it is unclear that the timing of this study work that the electrification goal has been met. However, meeting such targets will require connecting rural areas to the integrated electricity grids where technically and economically feasible, as well as deploying small-scale renewable energy systems [11]. However, due to the difficulty of extending the integrated electricity grids to underelectrified areas, off-grid renewable energy technologies could offer a viable solution. Specifically, such grids: (1) are less constrained by the archipelago geography and (2) they have much lower carbon emissions than equivalent fossil fuel technologies $[1,11,21]$. 


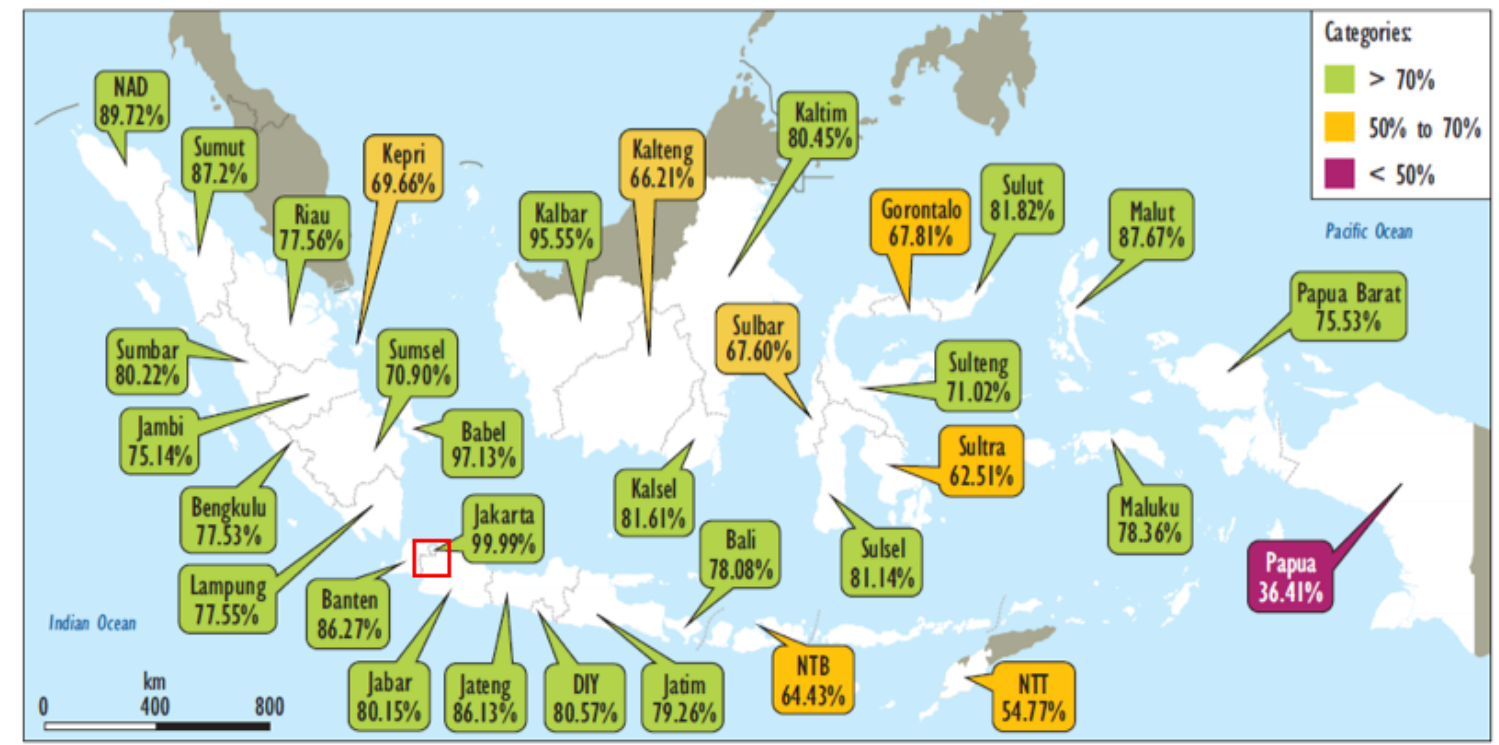

Figure 1-2. Indonesia's electrification rates in 2013, modified from International Energy Agency [11]. The red square represents the study area in West Java. The gray shading indicates neighboring nations.

However, not all renewable energies are equally suited for rural electrification. While hydropower and geothermal currently generate the largest portion of electricity $(6.5 \%$ and 4.8\%, respectively) in Indonesia [11], their suitability for rural electrification projects leaves much to be desired. For hydropower, the technical potential is high, but its energy resources is usually too far from demand centers [11]. As for geothermal, the development is challenged by a suite of environmental regulations: by law, geothermal energy development is considered a mining activity, and $42 \%$ of Indonesia's geothermal energy is located in forest conservation areas, in which all mining activities require presidential approval and have been halted under moratorium [11]. In addition to spatial constraints, both technologies typically require significant up-front investment and are difficult to scale. On the other hand, solar photovoltaic technology is considered an excellent candidate for rural electrification in Indonesia because of Indonesia's high average daily insolation (4.5 $\left.-5.1 \mathrm{kWh} / \mathrm{m}^{2}\right)[11,21]$, and because the non-electrified portion of the population are often scattered over remote islands and communities with limited to no grid connections [21]. 
Given Indonesia's archipelagic geography and its vested interest in abating the effects of climate change, distributed solar PV systems are an excellent candidate for electrification of the rural population of Indonesia.

While distributed solar PV may be a low-emission energy source, there are roadblocks to wider implementation of this technology for rural population. First, deployment of large-scale solar PV infrastructure may have negative impacts on land and water resources: for example, farmlands and grazing lands are land covers that are occupied most extensively by PV infrastructures in California, and these areas of food production are displaced by energy production [25]. Moreover, occupation by PV may alter the microclimate, carbon cycling, and other variables that control the land's ability to perform various ecosystem services and its ability to produce food, including heightened erosion of the soil under the PV panels $[7,26,27]$. These changes in the PV-occupied land presents a greater concern for a land-limited country like Indonesia, and crop-PV co-location is designed specifically to address it $[14,15]$. However, approaches to verifying the viability of co-location from physical perspectives are rare $[28,29]$. Chapter 3 aims to address this gap through analyses of soil nutrient and hydrologic variables under a revegetated solar array.

Another roadblock to country-wide deployment of distributed solar PV is that Indonesia's national utility company Perushaan Listrik Negara's (PLN) lack of funding allocated for remote, renewable energy-based electrification, and the fact that investments in such electrification schemes are almost solely from charities or private organizations [12]. Therefore, the feasibility and the benefits of solar PV-based for rural village grids are contingent on the profitability of such grids along with local participation and employment generation. For example, a performance model of a solar PV installation co-located with 
aloe cultivation and aloe gel production in drylands suggests that the combined land use is likely to abate the cost of solar power generation in an off-grid setup, and that a landowner could even profit from such land use in a grid-tied setup by selling excess electricity [8]. Feasibility of co-location in Indonesia has yet to be studied, and Chapter 4 aims to model the environmental and economic performance of the co-location systems through a lifecycle approach, as well as determine the expected and unexpected environmental and socioeconomic benefits from the co-location scheme. 


\section{CHAPTER 2}

\section{HYPOTHESES AND OBJECTIVES}

This study addresses two of the major controls of the viability of rural electrification using off-grid PV and co-location of PV with vegetation. Chapter 3 investigates the impact of large-scale PV installations on the hydrologic, chemical, and textural properties of the soil. This chapter takes advantage of an established large-scale PV facility with a rare, ongoing revegetation effort in Colorado. Although the Colorado site represents a different climatic regime than that of Indonesia, the study provides a set of critical constraints not otherwise available on the impact of PV arrays on the soil's ability to host vegetation in the context of combining crop cultivation with PV electricity generation. Chapter 4 investigates economic constraints of deploying solar PV for rural electrification in scenarios where PV infrastructures are integrated into existing cash crop cultivation. It builds on the results from Chapter 3 but is amendable to being updated as new data is acquired from Indonesia in future work.

\subsection{Hypotheses}

1. Chapter 3: Installation and operation of solar PV infrastructure will significantly alter the ecosystem function by changing soil particle size distribution, volumetric soil water content, and unsaturated soil hydraulic conductivity.

2. Chapter 4: When off-grid, small-scale, PV is co-located with cultivation of a cash crop, the economic benefits from the cash crop can offset the cost of installation and operation of the PV infrastructure, resulting in net return.

3. Chapter 4: Implementation of a stand-alone integrated PV-crop cultivation system may provide additional environmental or socioeconomic benefits, such as 
retrofitting existing diesel generators, employment generation, and increase and diversification in economic activities in the remote rural regions with no-grid accessibility.

\subsection{Objectives}

1. Study the impact of the large-scale solar operation on surficial soil parameters such as particle-size distribution, soil water content, and unsaturated soil hydraulic conductivity through comparison of surficial soils found under a revegetated solar PV infrastructure and under an adjacent natural land cover.

Particle-size distribution, soil water content, unsaturated soil hydraulic conductivity, and carbon and nitrogen content of the soil were measured in transects at a large-scale solar PV facility and at an adjacent undisturbed area to compare the distribution of the aforementioned variables in the two different land covers.

2. Model the economic and environmental performance of a co-located land use by performing detailed life cycle analysis (LCA) for stand-alone solar PV, a local crop ideal for colocation, and a hypothetical co-located solar-crop system to explore the tradeoffs and synergies (in the context of energy, greenhouse gas emissions, land footprint, and economic feasibility) between the two emerging land uses (energy \& food) in Indonesia.

The LCA models were implemented in R (ver. 3.4.3) with Indonesia-specific values from literature and field studies to simulate the greenhouse gas emissions and offsets, energy input and outputs, land footprint, and economic outcome of the four land uses: standalone PV, patchouli, co-located PV-patchouli with full module density (400 kWp ha$\left.{ }^{1}\right)$, and co-located PV-patchouli with half module density $\left(200 \mathrm{kWp} \mathrm{ha}^{-1}\right)$. A range of values representing conditions in Indonesia are evaluated to produce a robust description of the 
likelihood of different economic and environmental outcomes. Although tuned to Indonesia, this LCA framework is more widely applicable.

3. Examine the potential of combined land use for improving rural livelihoods including opportunities for processing agricultural products locally, employment generation and rural electrification.

The energy output from the solar PV in standalone solar PV system and co-located PV-patchouli system was compared to the energy demand of a model Indonesian village to determine the type and extent of public and commercial energy use the co-located system will support. 


\title{
CHAPTER 3
}

\section{IMPACTS OF SOLAR PHOTOVOLTAIC ARRAYS ON THE SOIL PHYSICOCHEMICAL PROPERTIES: A PRELIMINARY INVESTIGATION ON A SOLAR PV TEST SITE IN COLORADO, USA}

\begin{abstract}
With awareness of the global climate change, the communities around the globe are deploying solar photovoltaic technology to transition to sustainable energy production at an unprecedented rate. However, in the context of ever-increasing competition for land between food and energy production accompanying ever-growing global population, the land-use footprint of the photovoltaic technology is becoming problematic. An emerging strategy for mitigating the impact of the land requirement issue is to co-locate photovoltaics with native flora or an ideal crop. The success of such a co-location will strongly depend on (1) identifying the impact of PV array on the environmental conditions of the soil that allow the plants to thrive and (2) incorporating the findings on the impact with the design of the co-location to elicit environmental benefits for both the plants and the PV array. To assess the feasibility of the co-location strategy, the critical environmental parameters including infiltration rates, soil moisture, total carbon and nitrogen, and particle size distribution along two transects in a revegetated photovoltaic arrays (treatment) and along one transect in an adjacent undisturbed plot (control) were measured along transects.

The presence of photovoltaic arrays caused a large variation of volumetric soil moisture, as well as a generally elevated level of volumetric soil moisture. Unsaturated hydraulic conductivity was higher in the undisturbed plot, which was determined to be caused by compaction during the installation and operation of the photovoltaic array.
\end{abstract}


Decline in total carbon and nitrogen levels in soils under soil adjacent to the photovoltaic array implied lower biomass productivity and carbon sequestration capacity. Despite these changes, a previous study of the revegetation following the installation of this array indicated that it was nevertheless sufficient to suppress erosion and provide wildlife habitats. While the human activity required for the construction and the maintenance of the photovoltaic facility may negatively impact the plant growth, many studies show that the co-location is feasible. However, the fact that the carbon and nitrogen levels in the soil did not recover to the pre-PV construction levels suggested that the soil's ability to sequester carbon was compromised to some degree. In order to minimize the loss in soil's ecosystem function, it is recommended to minimize the disturbance in the topsoil during construction of PV arrays in consideration for the crop-PV consideration design. While different ecological zones may require a specific type of co-location strategy, the methodology of this study could be replicated and adjusted for the specifics of respective environments. 


\subsection{Introduction}

To meet the demand of the rising population, global total primary energy supply (TPES) increased from 6,101 million tons of oil equivalent (Mtoe) to 13,699 Mtoe between 1973 and 2014 [2]. This demand, coupled with the growing global awareness of global climate change and water pollution as the environmental consequences of heavy reliance on conventional fossil fuels, has led to a rapid expansion of low-carbon resources $[1,3,4,30,31]$. In particular, solar photovoltaics (PV) has become one of the fastest growing energy technologies in the recent years due to technological advancements and favorable policies $[31,32]$. Furthermore, solar power has the largest technical potential energy out of any renewable technologies [1,33-35], and Solar PV is expected to represent anywhere between $19.9 \%$ to $29.0 \%(32,700 \mathrm{GW}$ to $133,000 \mathrm{GW})$ of the global total electricity demand by 2100 [31].

While solar PV is a low-carbon technology, its large-scale, non-integrated deployment requires around 5 ha for $1 \mathrm{MW}$ [14], which is a larger land requirement than some non-renewable energies, such as coal, nuclear, and natural gas [36]. Once occupied by PV, the land is used for collecting solar energy to be converted to electricity instead of leaving it to perform ecosystem services, such as carbon sequestration [25]. If the total installed capacity increases to anywhere between $32,800 \mathrm{GW}$ to $133,000 \mathrm{GW}$, it will effectively lock away 82 million to 333 million hectares of the global terrestrial surface from performing ecosystem services. Currently, approximately $36 \%$ of the world's land use is devoted to agriculture [37]. Despite the increasing yield from improvements in cultivation practices and technology, increasing population, growing water scarcity, and soil degradation are likely to require more land devoted to agricultural use [37]. Thus, it is anticipated that securing food production will be one of the strongest contenders for the 
remaining lands on the planet [37]. Additionally, forest cover has decreased from $31.8 \%$ to $30.8 \%$ between 1990 and 2015 [37], and greenhouse gas emissions resulting from deforestation (loss in live biomass and biomass accumulation) has also been found to exacerbate climate change [38-40].

Strategies to mitigate the land use impacts of solar PV installation and cumulative impacts of the operation of PV facilities on ecosystems, agricultural facilities and habitats have been a focus of continuing research. One of the emerging mitigation strategies is to co-locate PV electricity production with another land-occupying activity, such as cultivation of a profitable crop that fits the physiological requirements for co-location or revegetation of PV-occupied land with native flora [7,14-16,41]. Co-location of PV with crop production or revegetation effort was first suggested by Goetzberger and Zastrow [42], and it involves placement of an ideal crop or plant between PV modules with three different approaches: vegetation-centric, energy-centric, and integrated vegetation-energy-centric [16]. The vegetation-centric approach to co-location maximizes biomass production activities and minimizes impact on the existing vegetation or vegetation management activities from the deployment of PV modules, whereas an energy-centric approach is intended to maximize solar energy output and adhere as much as possible to the standard solar energy development practices while producing biomass under and around the solar installation [16].

No matter which approach to co-location is used, the impact of PV deployment on the land must be assessed and the mechanisms governing this impact be identified. The findings from this assessment can then be used to optimize the environmental and financial outcomes of the co-location, and ultimately will determine whether the strategy is viable. While cradle-to-grave approaches to quantifying the carbon and energy footprints of 
photovoltaic facilities are abundant [43-49], field-level investigations on the impacts of photovoltaic arrays on ecosystems (e.g. hydrologic, geomorphological, nutrient status, microclimatic, etc.) related to mitigation strategies such as colocation of vegetation on solar PV sites $[7,41]$ are scarce. This is a critical research gap, as the factors that affect soil's capacity to support vital ecosystem services such as primary production and carbon sequestration are an important part of the design of PV-crop co-location.

Cook and McCuen's modeling study [27] indicated that gravel or bare ground cover commonly built under the PV arrays may increase peak discharge of storm runoff more than do the PV panels themselves. Furthermore, the concentrated discharge from the raindrops captured by the PV panels were found to have greater kinetic energy than the raindrops themselves, which increases soil erosion at the base of the panels [27]. A study of water flow and bulk actual evapotranspiration (AET) in crops under PV modules revealed that the shading from the PV panels reduced the AET by $10 \%$ to $40 \%$ under modules compared to full sunlight [50]. In addition to the reduction of AET under the panels, Barron-Gafford et al [51] found that the changes in albedo, vegetation, and land cover from the construction and operation of large-scale PV plants cause a "heat island" (PVHI) that raises the temperature over the power plants by $3-4{ }^{\circ} \mathrm{C}$ compared to the surrounding wilderness area [51].

Even though solar arrays can significantly affect soil-hydrological processes, field studies specifically investigating the impact of the PV array on abiotic soil factors such as the hydrology and soil physicochemical properties are lacking. Moreover, studies on the recovery of these properties following revegetation in solar areas have never been conducted, and the findings from such study will be critical for implementing the colocation design in pre-existing and future solar arrays. 
Utility-scale solar energy (USSE) infrastructure requires extensive landscape modification including native vegetation removal, land grading and refilling top soil and compactions. The landscape modification may transform the ecosystem functions of the soil in the disturbed landscape impacting vegetation recovery, carbon-nitrogen dynamics, and moisture dynamics. Hence it is important to investigate if reintroducing native vegetation at these sites can successfully restore ecological and hydrological functions of the soil.

To address this knowledge gap, we investigated the changes in infiltration, soil moisture, soil carbon and nitrogen content, and soil particle size distribution in a solar PV infrastructure seven years following a revegetation experiment with native grasses, and compared to those of an adjacent undisturbed grassland. We hypothesized that presence of a PV array introduces greater hydrologic variability to the soil below by providing shielding portions from sunshine and rain, which effectively concentrates moisture directly beneath the solar panel edges. The heterogeneity in the distribution of rainfall could be incorporated in the placement of the crops to either concentrate the rainfall onto the crops in drier climates or shield the direct rainfall onto the crops and avoid ponding in wetter climates.

\subsection{Materials and Methods}

\subsubsection{Site Description}

The study site was located in the 1.1-MW solar PV array at the National Renewable Energy Laboratory's (NREL's) National Wind Technology Center (NWTC). The solar PV array is located along the east slope of the Front Range in northern Jefferson County, Colorado [52]. The site is subjected to strong winds in winter and intense thunderstorms in 
late spring and summer [52]. Total average annual precipitation from 1997 to 2012 was 374 millimeters, and average annual temperature is $10{ }^{\circ} \mathrm{C}$.

The array was built in 2009 by SunEdison, Inc. to sell electricity to the NREL [52]. Originally, the site had a slope that was slightly greater than $2 \%$, but in preparation for construction of the solar PV array topsoil was largely removed and the site was graded and leveled to less than $1 \%$ slope then compacted [52]. The soils at the site were composed of unsorted alluvial/colluvial deposits that were exposed to soil-forming processes that had extensively oxidized the native iron and leached the clay minerals [52]. The area encompassing the study site had historically been a xeric tallgrass prairie, but grazing and other activities have altered the flora while leaving the paleosols and clay-enriched subsoils intact [52]. Following the construction of the solar PV array, SunEdison was required to revegetate the disturbed area as per NREL's policies for minimizing the impact from development of DOE property [52]. However, NREL's preexisting guideline for choosing seed mixes for revegetation was designed for addressing construction of structures other than that of solar PV, and therefore a portion of the array was dedicated to a vegetation test-plot study in 2010 [52]. This experiment was conducted from July $24^{\text {th }}$ to $26^{\text {th }}$ of 2017 , seven years after the initial revegetation.

\subsubsection{Geometry of Measurement and Sampling}

For this study (not the vegetation test-plot study), the field measurements were taken in a portion of the 1.1-MW solar PV array in which a revegetation study had been conducted as part of an effort to restore the soil surface beneath the PV array to the condition similar to that of the soil surface before the construction of the solar PV. The revegetated portion of the PV array was a parallelogram $49.10 \mathrm{~m}$ by $9.30 \mathrm{~m}$ that was 8.60 
m high, and it includes four rows of panels in the northeastern corner of the array (Fig. 31a, c). The PV panels are mounted on top of mono-axial tracking systems that are oriented north-south so that the panels can face east in the morning and progressively tilt west towards the end of the day. The base-of-systems hold the PV panels at approximately one meter above ground [52].

The measurements and samples were taken along three transects in the revegetated portion and along another transect in an undisturbed area adjacent to the revegetated portion (Fig. 3-1a). For the transects in the revegetated portion of the array, the sampling locations along the transect were directly below the edges of the panel ("east edge" and "west edge"), the central location under the panel ("center space," directly adjacent to the column of the mounting system), and the space between each row of panels ("interspace") (Fig. 3-1b). As for the transect in the adjacent undisturbed area, the sampling locations were placed at distances equivalent to the sampling locations along the revegetated transects. No measurements or sampies were taken in a non-revegetated portion of the photovoltaic array as civilian access was restricted from that area.

\subsubsection{Soil Hydrology}

The soil variables measured in the field were VSM and infiltration rate, which was used to calculate unsaturated hydraulic conductivity (UHC). Two measurements for each variable at each sampling location were determined to be adequate given the limited period of access to the site. VSM was measured with a pair of $15-\mathrm{cm}$-long soil water content reflectometer (CS655, Campbell Scientific Inc., UT, USA) 

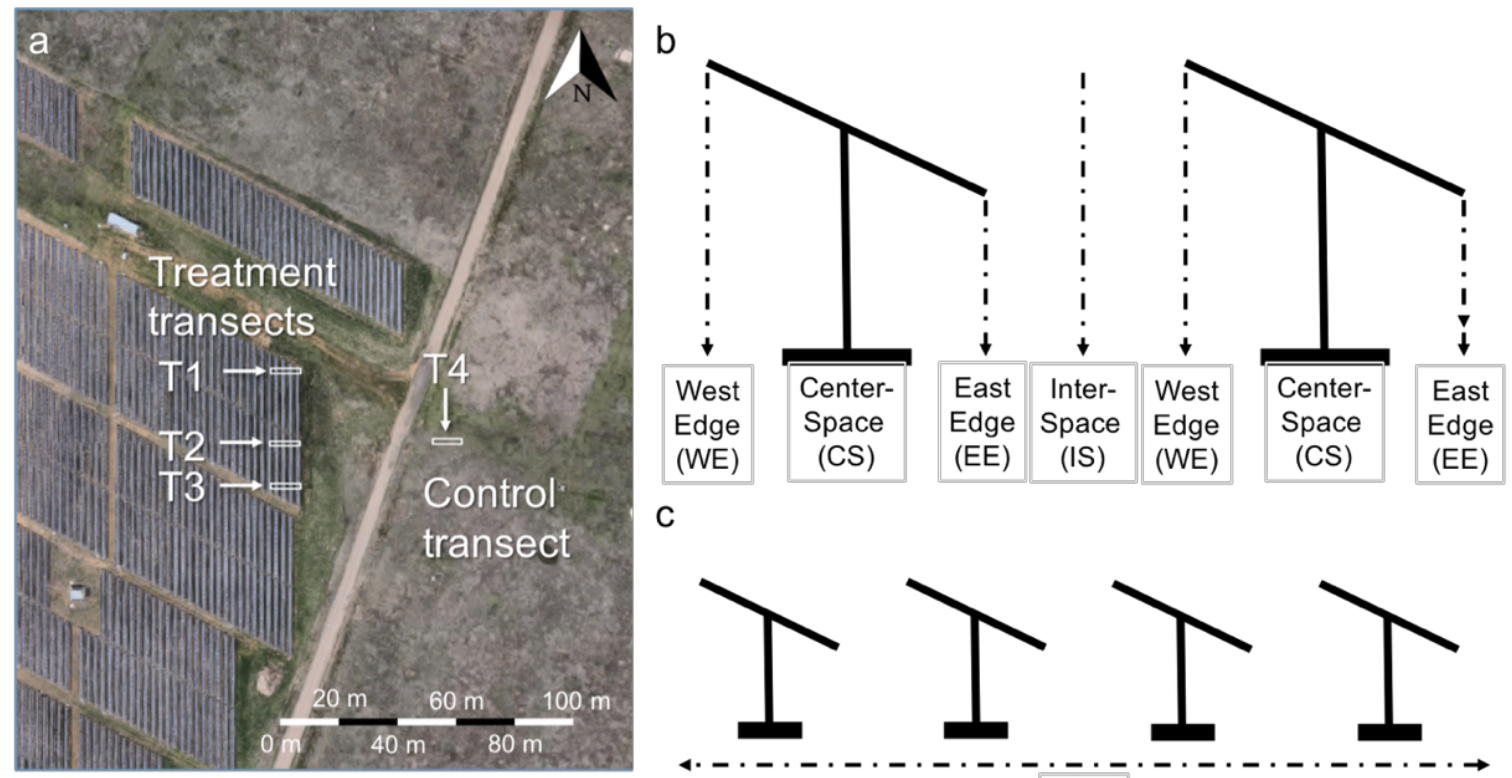

C

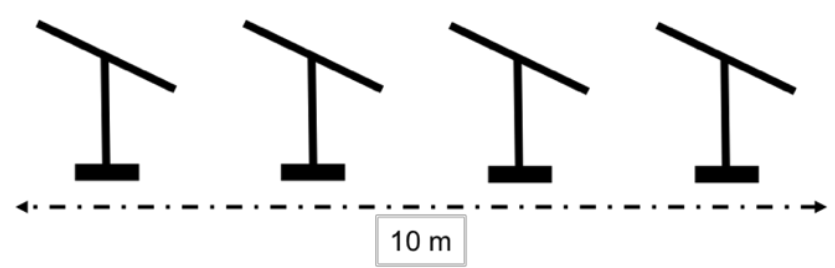

Figure 3-1. (a) A satellite image obtained from Google Maps shows the location of the treatment transects and the control transect near the northeastern corner of the photovoltaic facility at the NWTC. The treatment transects T1 to T3 are located in the revegetation study area, and the control transect T4 is located in an undisturbed area adjacent to the PV array. Measuring and sampling locations are determined as a function of their position relative to the photovoltaic array (b). Both edge locations are approximate, as the exact location of the edges along the horizontal transect varies with the daily swivel of the tracking array (b). Each symbol of a photovoltaic module represents a row of module (c). A transect encompasses four rows of PV modules and their relative positions along the horizontal transect (c). Figures $\mathbf{b}$ and $\mathbf{c}$ are not to scale. 
that was fitted into an HS2 display unit (Campbell Scientific Inc., UT, USA). Infiltration rates were measured using mini disk infiltrometer (Decagon Devices, WA, USA), which measure the amount of water infiltrating into the soil in a given time interval [53]. The mini-disc infiltrometer, with an adjustable suction and a small footprint (circular measuring area of 5-cm diameter porous stainless-steel disc), is ideal for measuring the variability unsaturated hydraulic conductivity in multiple points along transects. The unsaturated hydraulic conductivity for the applied suction was calculated by a method proposed by Zhang, which uses cumulative infiltration, time, and van Genuchten parameters for different soil texture classes $[54,55]$. The infiltration rates were measured with a suction of $1 \mathrm{~cm}$ to shorten the runtime of each trial, and the van Genuchten parameter for a sandy loam was used for the hydraulic conductivity calculation as per United States Department of Agriculture's Web Soil Survey [52,56].

The hydrologic measurements were made on treatment transects T1-T3 and the control transect T4 on the $24^{\text {th }}$ and $25^{\text {th }}$ of July 2017 . The measurements were repeated for $\mathrm{T} 2$ and $\mathrm{T} 4$ on the morning of the $26^{\text {th }}$ after a precipitation event from the previous evening. The accumulated precipitation was $6.6 \mathrm{~mm}$, and the wind direction ranged mostly from southwesterly to northwesterly (Fig. 3-2). The precipitation and wind data were collected by the M2 station, which is a meteorological tower $80-\mathrm{m}$ tower located about 200-meters northwest of the PV array. The tracking solar array was facing west at the end of the day, and during the precipitation event in the evening.

\subsubsection{Lab Measurement}

In addition to the field measurements, soil samples of approximately 100 grams were taken with a garden trowel from the surface to the 5-cm depth within a $5-\mathrm{cm}$ diameter 
at each sampling location. Each sample was air-dried and weighed. After drying, grains larger than $2 \mathrm{~mm}$ were removed with a sieve and a brush then weighed. The remaining portion of each sample (less than $2 \mathrm{~mm}$ in diameter) was separated into two halves using a riffle sampler (Humboldt Mfg. Co. IL, USA).

One-half of the $<2$-mm portion from each sample was treated with bleach (24 h) to remove organic matter, then was analyzed for grain size distribution using a laserdiffraction particle size analyzer (LS 13 320, Beckman Coulter, Inc., CA, USA). The particle size analyzer measures the size distribution of the particles suspended in a liquid using the principles of light scattering, and it offers a dynamic diameter range of 0.017 and $2000 \mu \mathrm{m}$ [53]. The samples were measured using the aqueous liquid module (ALM) of the analyzer, and the particles were suspended in water.

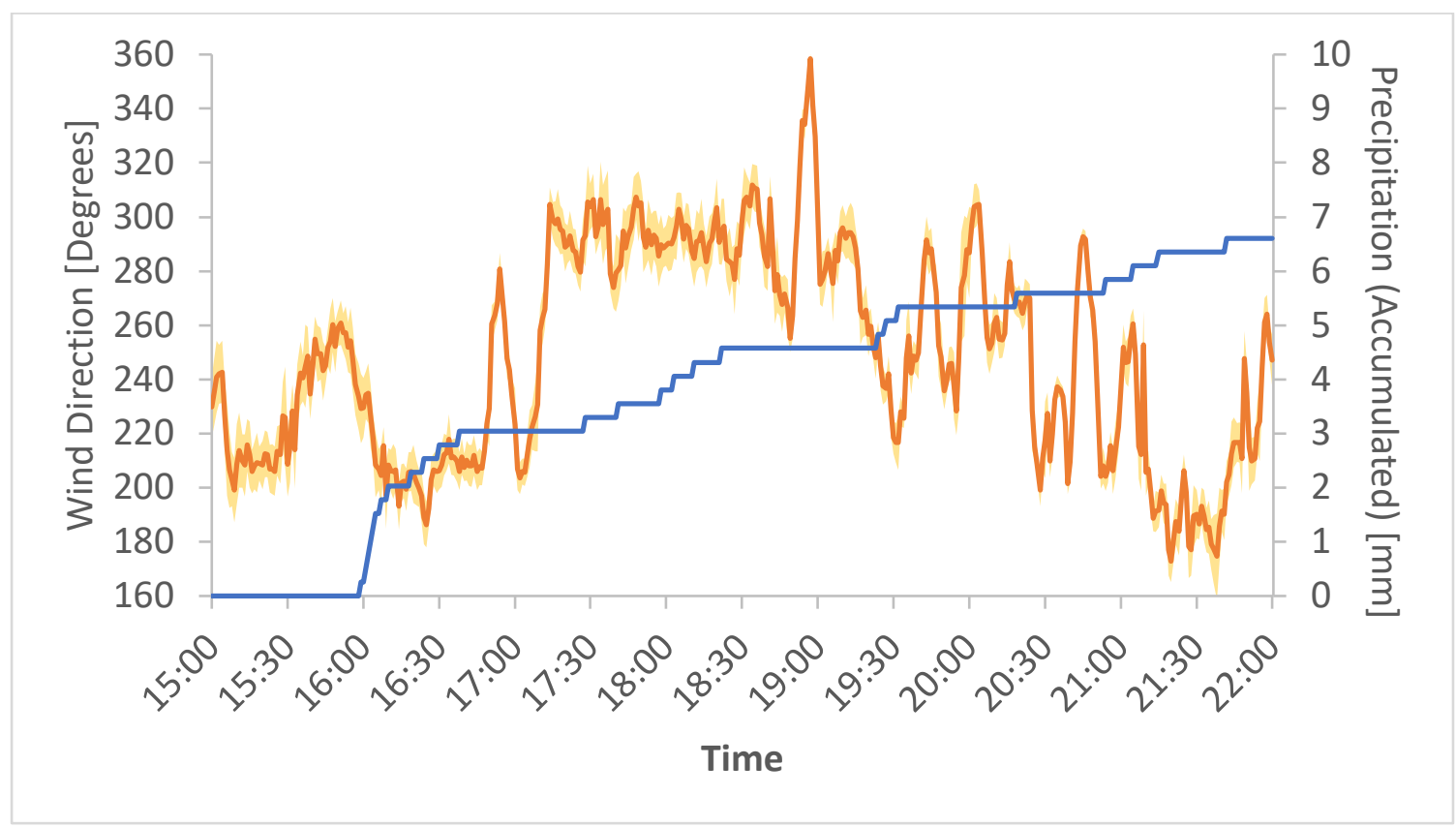

Figure 3-2. Average wind direction at 2-meters from the ground and accumulated precipitation during the precipitation event on July $25^{\text {th }}, 2017$. Average wind direction and standard deviation are shown in bright orange and faded orange, respectively, and the accumulated precipitation is shown in blue. 
The other half of the $<2-\mathrm{mm}$ sample was analyzed for total carbon and nitrogen at Brookside Laboratory, Inc. in New Bremen, $\mathrm{OH}$, using combustion methods that were described in detail in Nelson and Sommers and in McGeehan and Naylor [57,58]

\subsubsection{Statistical Analysis}

Analysis of variance (ANOVA, R ver. 1.0.143) was performed for mean soil moisture, hydraulic conductivity, total soil carbon and nitrogen, and grain size to detect any significant difference in these variables between the revegetated solar PV plot (Treatment) and the undisturbed plot (Control), in addition to any variation amongst the sampling locations relative to a solar PV module (east edge, center space, west edge, and interspace). The sample size for each ANOVA is described in the caption for the corresponding figure.

\subsection{Results}

VSM was significantly higher in the solar plot than the control plot $(\mathrm{p}<0.05)$ both before and after the rain event and also had a much greater variation (Fig. 3-3a). This variation is illustrated by the difference in soil moisture between relative positions, and WE had a significantly higher VSM after the precipitation event than before (Fig. 3-3b).

As a whole, there was no significant difference in unsaturated hydraulic conductivity between control and treatment (Fig. 3-4a). However, the variation in the treatment highlighted in Fig. 3-4b, where CS had a significantly higher hydraulic conductivity than all other relative positions and the control transect both before and after the precipitation event $(\mathrm{p}<0.05)$. 
is highlighted in Fig. 3-4b, where CS had a significantly higher hydraulic conductivity than all other relative positions and to the control transect both before and after the precipitation event $(\mathrm{p}<0.05)$.

The treatment had a significantly lower $(\mathrm{p}<0.0001)$ carbon and nitrogen composition than the control (Fig. 3-5a, c). However, there was no significant difference ( $>0.05)$ among the relative positions within the treatment (Fig. 3-5b, d). There was a significant difference in $\mathrm{CN}$ ratio between the control and the $\mathrm{CS}$ and the $\mathrm{EE}(\mathrm{p}<0.05)$, but there was none among the relative positions within the treatment (Fig. 3-6).

The mean and median grain sizes of the control were significantly larger than the treatment $(\mathrm{p}<0.001)$. (Fig. 3-7a, b) Soil samples showed a greater heterogeneity and grain size in the control plot than in the solar array, and degree of sorting is directly proportional to the mean particle size (Fig. 3-7b).

Samples from the control group had significantly smaller mass portion of the coarse ( $>2 \mathrm{~mm}$ in diameter) fraction than the samples from the treatment group (Fig. 3-8). However, there was no significant difference in mass portion of the coarse fraction among the relative positions in the treatment (Fig. 3-8). 

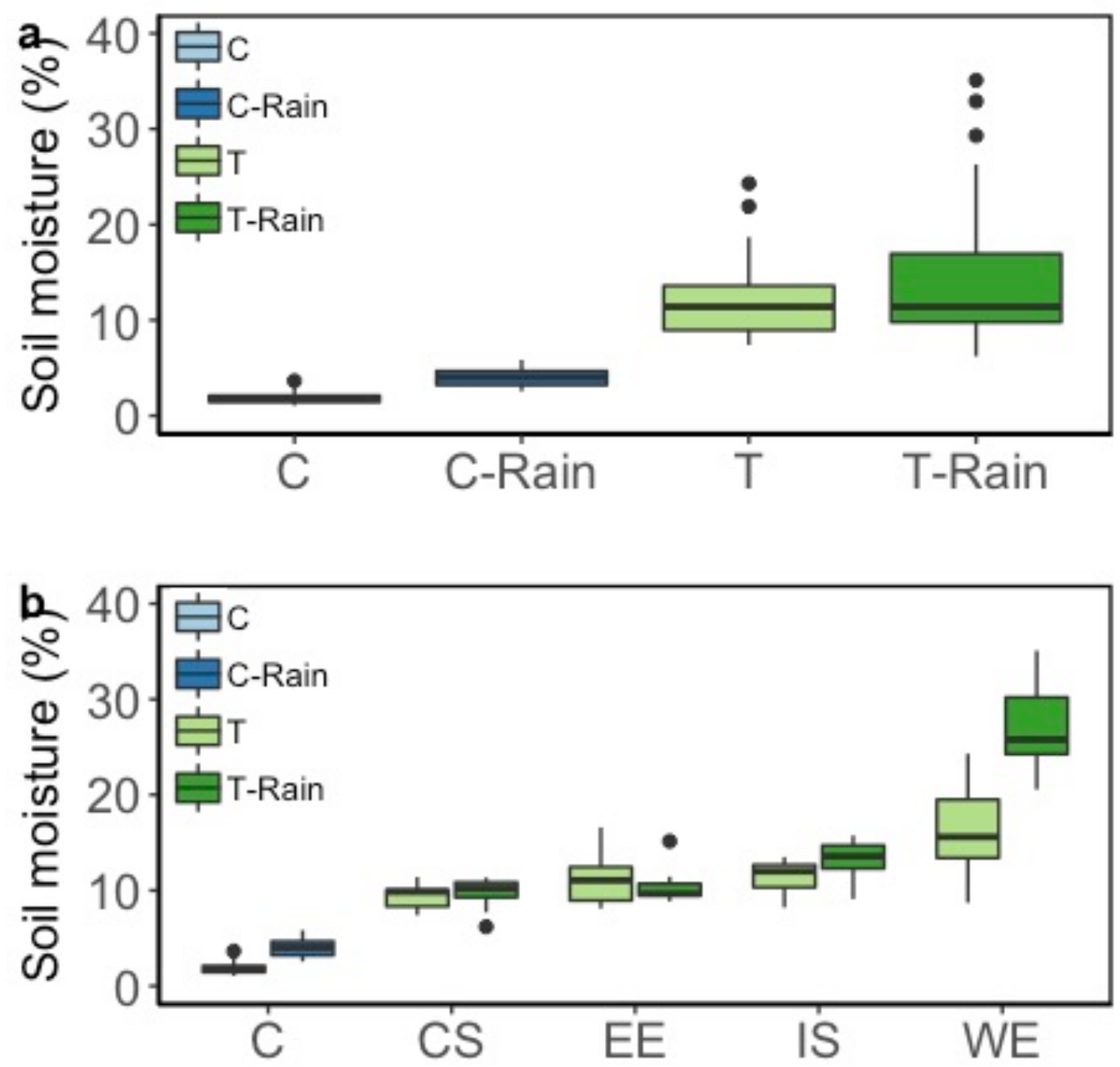

Figure 3-3. (a) Soil moisture before and after the precipitation event of the control transect ("C" and "C-Rain") is compared to soil moisture before and after the precipitation event of the treatment transect T1 ("T" and "T-rain"). For the control plot, there were 32 measurements before and after the rain event, and there were 64 measurements before and after the rain event for the treatment. (b) Soil moisture before and after the precipitation event of the control transect T4 ("C") is compared to that of the relative positions ("CS," "EE," "IS," and "WE") of the treatment transects. The middle notch denotes the median, the lower and the upper hinges correspond to the first and third quartiles, and the whiskers extend to 1.5 interquartile range above and below the median. As in (b), the control has 32 measurements before and after the rain, but each relative position has 16 measurements before and after the rain. 

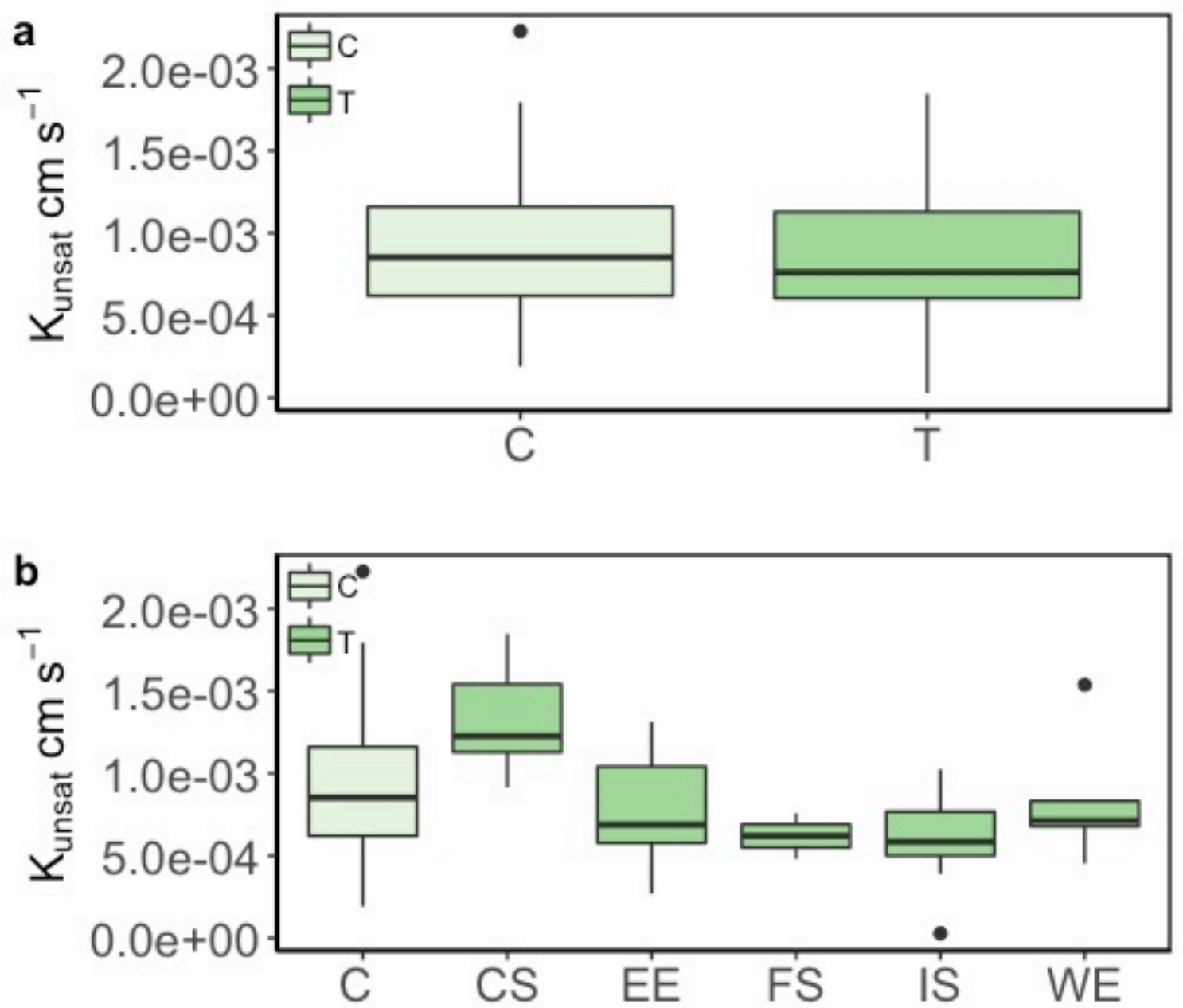

Figure 3-4. (a) Comparison of mean unsaturated hydraulic conductivity between the control ("C") and the treatment ("T") before the precipitation event. There are 32 measurements in the control and 64 in the treatment. (b) Comparison of mean unsaturated hydraulic conductivity between the control ("C") and the relative positions in the treatment ("T") before the precipitation event. The control has 32 measurements, and each relative position has 16 . For both figures, the middle notch denotes the median, the lower and the upper hinges correspond to the first and third quartiles, and the whiskers extend to 1.5 interquartile range above and below the median. 

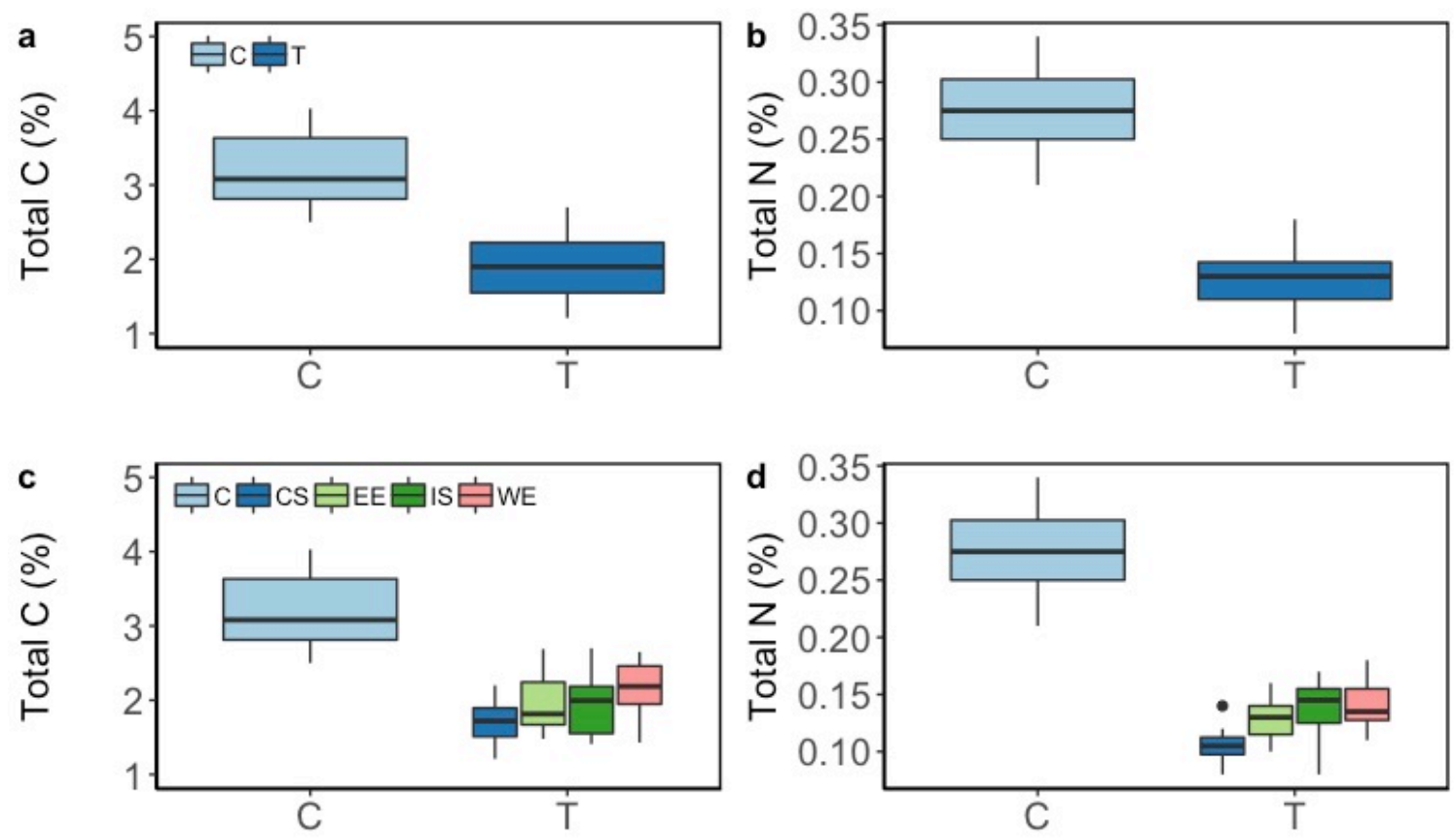

Figure 3-5. (a,b) Total carbon and total nitrogen of the control transect ("C $\mathrm{C}$ ") are compared to those of the treatment transects T1-4 ("T"). (c,d) Total carbon and total nitrogen of the control transect ("C") are compared to those of the relative positions ("CS," "EE," "IS," and "WE") of the treatment transects T1-4. The middle notch denotes the median, the lower and the upper hinges correspond to the first and third quartiles, and the whiskers extend to 1.5 interquartile range above and below the median. There are 16 measurements for the control and 64 for the treatment. 


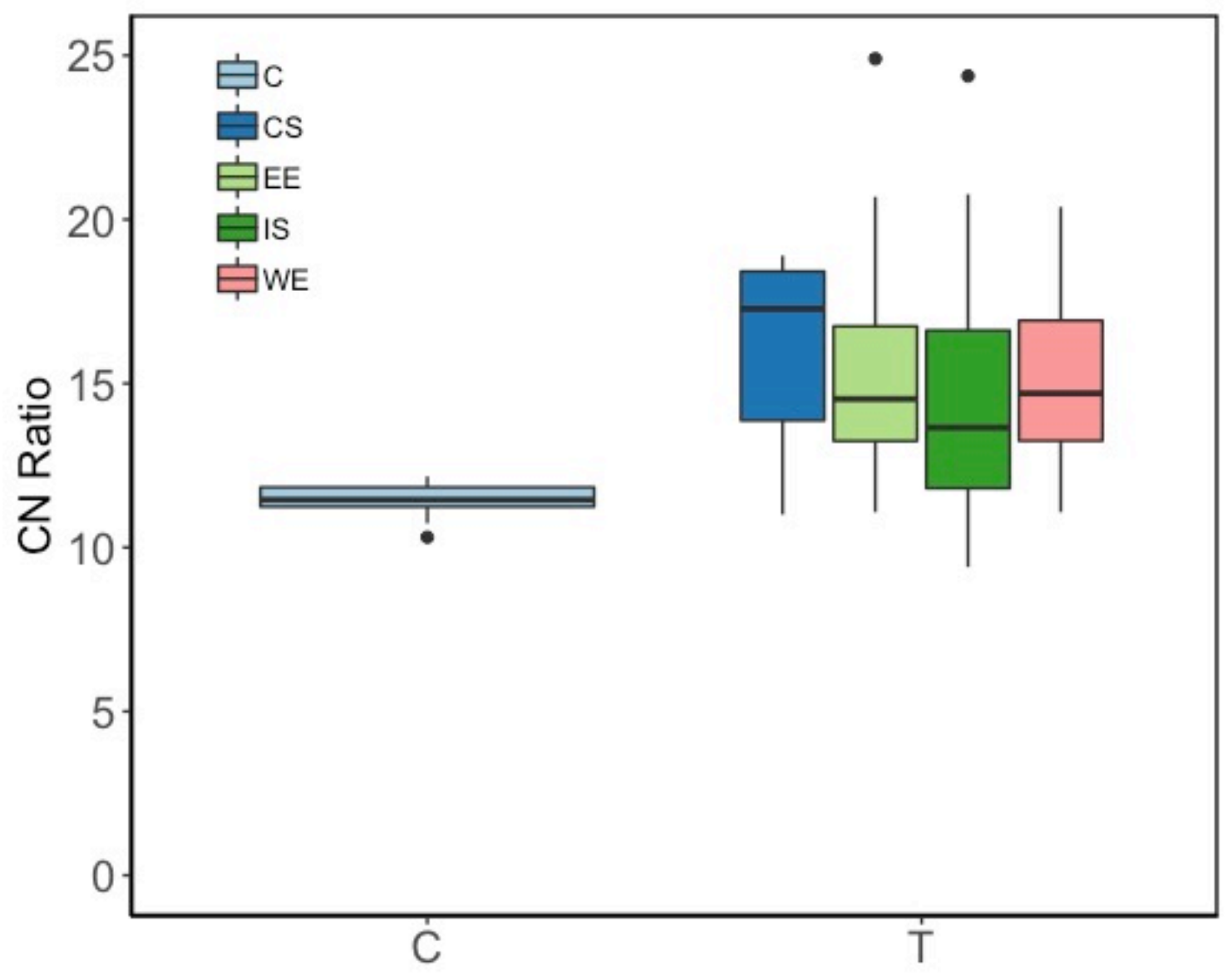

Figure 3-6. Comparison of mean $\mathrm{CN}$ ratio between the control ("C") and the relative positions within the treatment ("T"). The middle notch denotes the median, the lower and the upper hinges correspond to the first and third quartiles, and the whiskers extend to 1.5 interquartile range above and below the median. There are 16 measurements for the control and 64 for the treatment. 
a
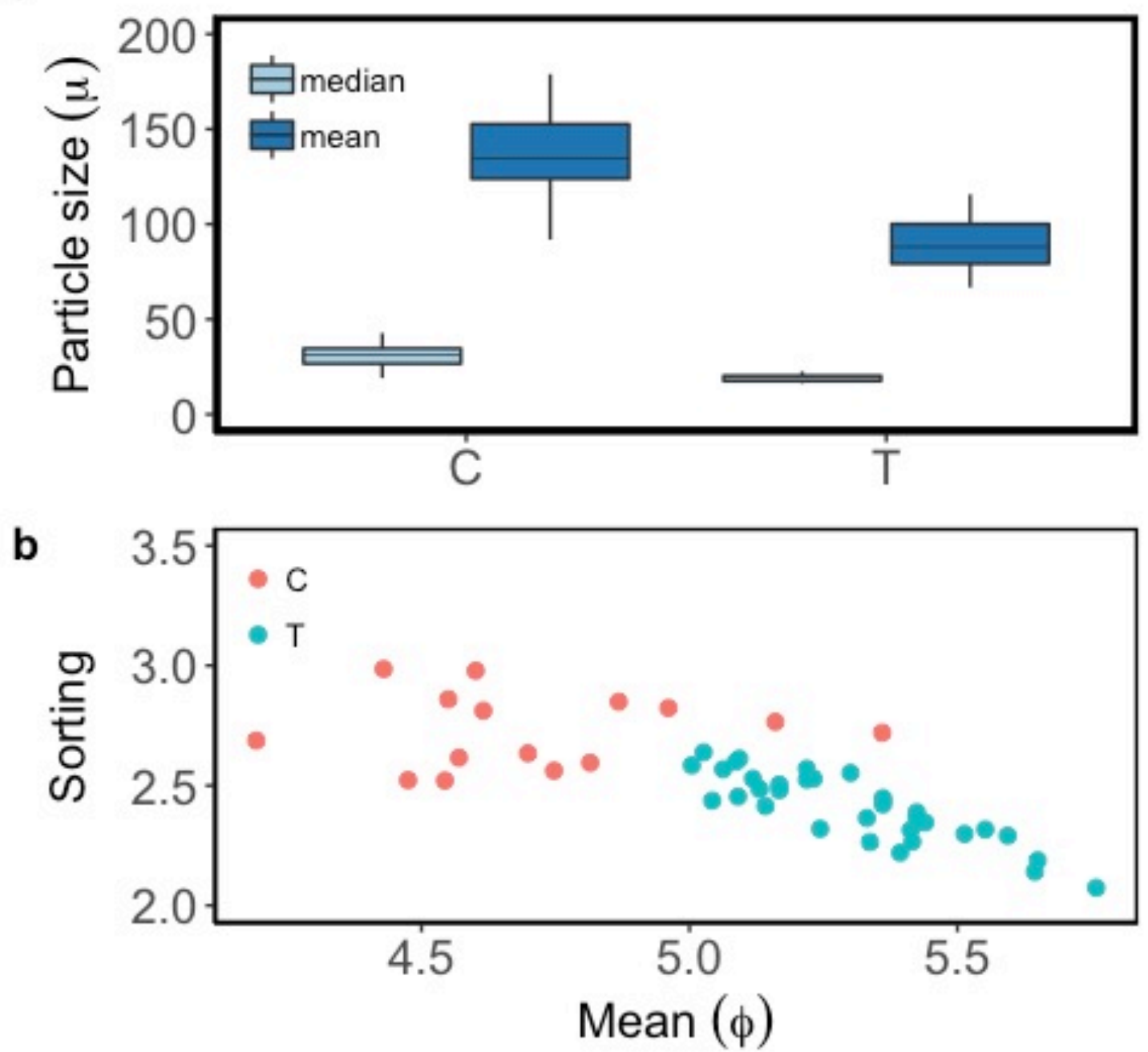

Figure 3-7. (a) Comparison of median and mean particle size in the soil samples from control and treatment transects. The middle notch denotes the median, the lower and the upper hinges correspond to the first and third quartiles, and the whiskers extend to 1.5 interquartile range above and below the median. (b) Sorting is plotted against the mean particle size on Krumbein phi scale for control and treatment groups ("C" and "T", respectively). There are 16 measurements for the control and 64 for the treatment. 


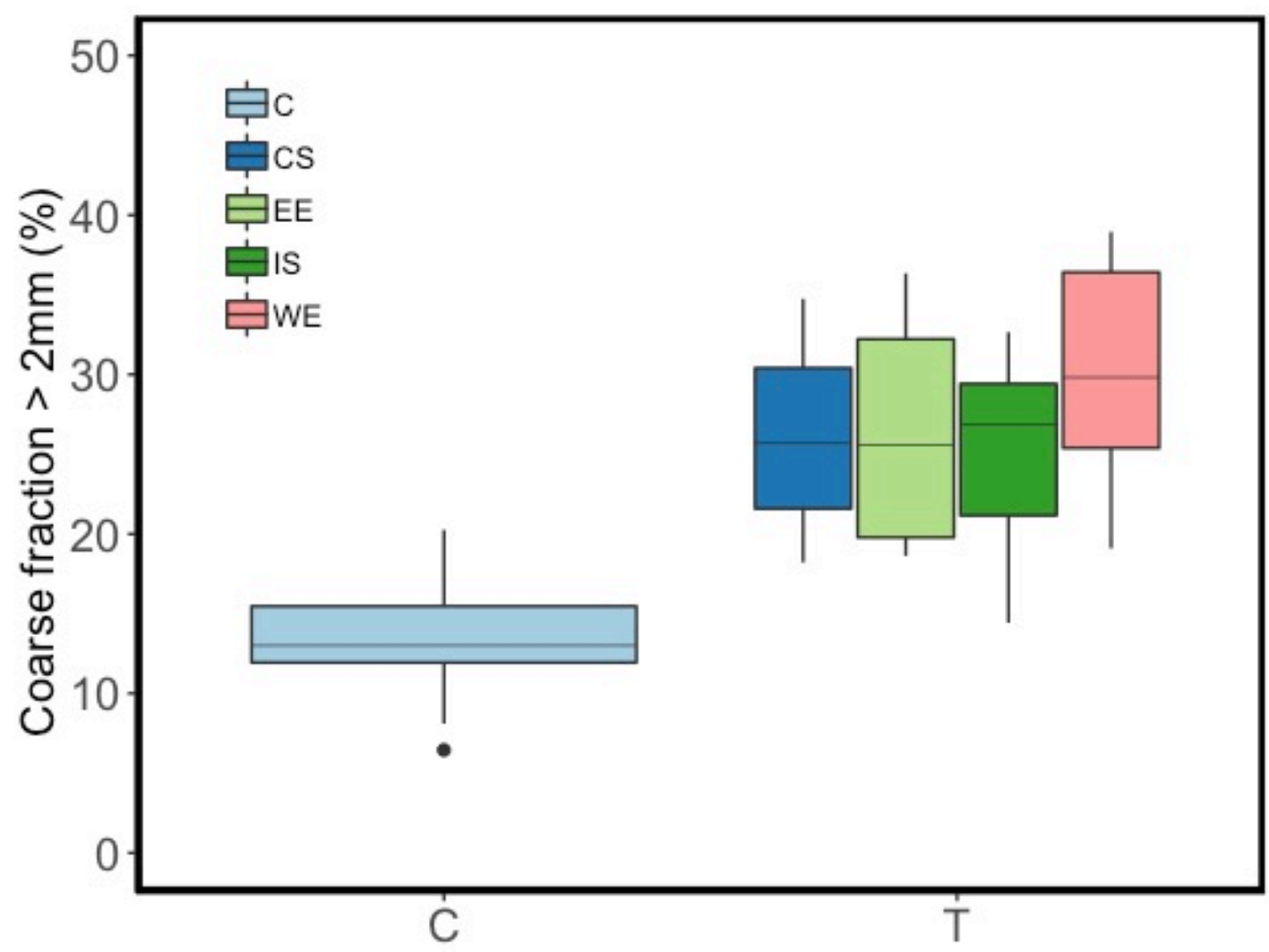

Figure 3-8. Mass fraction comparison of soil sample whose grain diameter is larger than 2 $\mathrm{mm}$ (lower threshold for pebble classification) by experimental group and relative positions. The middle notch denotes the median, the lower and the upper hinges correspond to the first and third quartiles, and the whiskers extend to 1.5 interquartile range above and below the median. There are 16 measurements for the control and 64 for the treatment. 


\subsection{Discussion}

Our results indicate that PV arrays can introduce considerable heterogeneity in the hydrologic, physical, and nutritional properties of the underlying soil. As for the distribution of moisture, there is large variation in the VSM of the transects in the PV array (treatment transects T1, T2, and T3), while that of transect in the adjacent, undisturbed area (control transect T4) is homogeneous (Fig. 3-3a). Moreover, the spread of VSM in the treatment transects before and after the rain decreased when they are broken down by relative positions instead of being shown collectively (Fig. 3-3a, b). Therefore, the difference in the relative positions of the measurement must have driven the heterogeneity in VSM.

Among the relative positions in the PV array, WE had the highest VSM of any relative positions before the rain, and it experienced the largest increase in the WE of any relative position. Furthermore, since the VSM measurements are an average of the top 15 $\mathrm{cm}$ of the soil, the actual increase VSM near the surface were likely even higher at the timing of the second measurement, which was the day after the rain. The likely cause of the elevated soil moisture and soil moisture increase post-precipitation is that the PV array was tilted to face west at the end of the day when the precipitation occurred. The rain that fell onto the panels trickled down to their WE, concentrating the rain to the soil directly beneath the WE (Fig. 3-9). In addition to the difference in the VSM by position, the VSM was generally higher in the treatment transects than they were in the control transect. The most likely cause behind the elevated VSM in the treatment transect would be the shading from the 


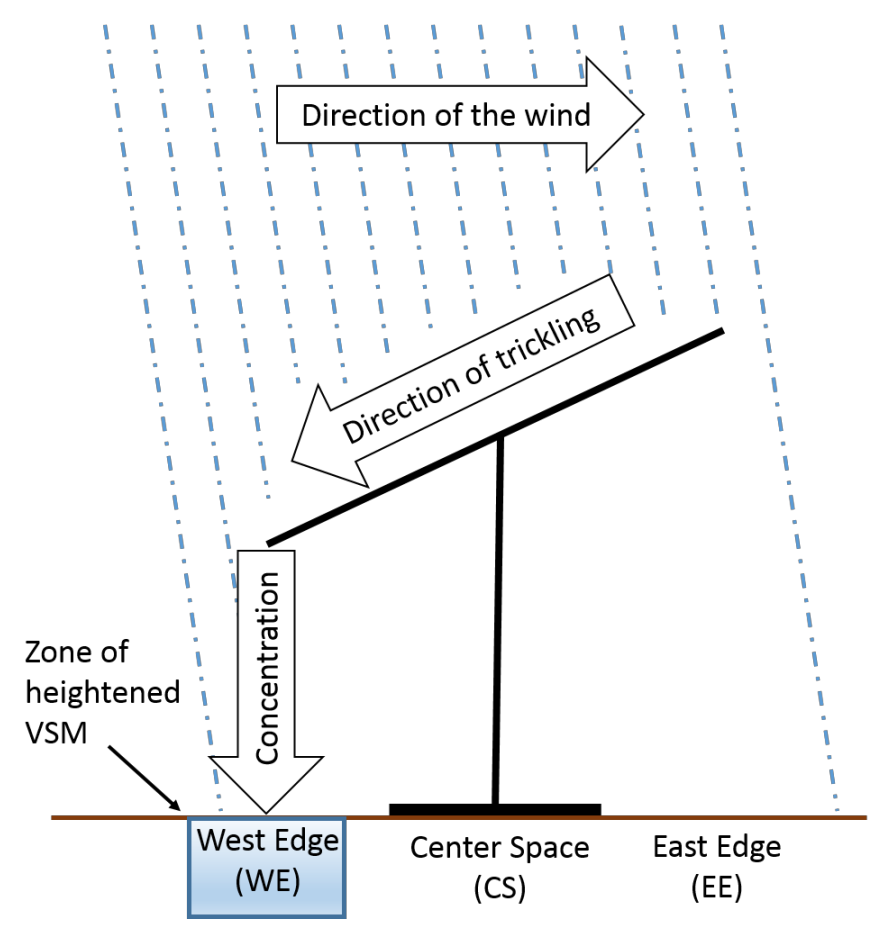

Figure 3-9. Simplified representation of the mechanism behind the rainfall concentration and elevation of soil moisture in the WE.

PV panels, which have been determined to decrease the AET by 10 to $40 \%$ in a previous study [50].

Even though primary particle size distribution (PPSD) had been identified as the most important factor in the infiltration rates of soils [59], there was no significant difference in the UHC between the control and the treatment transect as a whole (Fig. 34a). In comparison of the UHC of the individual relative positions, however, UHC was much higher in CS than in any other relative positions or in the control. Because of its location directly beneath the photovoltaic panel, it was likely that the soil at CS had experienced less compaction due to foot traffic. Compaction decreases hydraulic conductivity [60], and this relationship between soil compaction and hydraulic conductivity might explain the lack of difference in UHC despite of the significant difference between the particle size distribution between the two experimental groups. 
While measuring the degree of soil compaction is physically possible, obtaining permission for such measurement is improbable.

The significantly lower total carbon and nitrogen in the treatment transects T2 and T3 than in the control transect T4 was likely caused by the removal of topsoil during the construction of the NWTC photovoltaic array. The relatively low total carbon and nitrogen levels in the treatment transects compared to those in the control transect is consistent with the drastic reduction of soil organic matter and productivity immediately following the removal of topsoil in experiments on simulation of topsoil erosion via artificial removal [61-63]. While there is no information on the rate of soil development in this region, the $\mathrm{C}$ and $\mathrm{N}$ levels in the re-vegetated transects stayed lower than the control site for more than seven years after the construction of the solar infrastructure despite the successful revegetation [52]. The reduced $\mathrm{C}$ and $\mathrm{N}$ levels may indicate that the nutrient cycling and carbon sequestration of the soil have not fully recovered. The disparity between the recovery extent of the soil nutrients and that of the vegetation implies that the practice of leaving the pre-existing vegetation intact during the construction of PV array would be a preferable construction protocol to the revegetation following the conventional construction of the PV array, since carbon sequestration is a critical ecosystem service in the context of climate change. Another possible improvement to the co-location design to be explored in the same vein as ecological services is provision of pollinator habitats in under the PV array. The added pollinator habitats would locally restore insect pollinators, and the increased pollinator population would increase the primary production of nearby vegetations. Eventually, this would result in an increased land-use efficiency of the colocated design via increased crop yields, carbon sequestration, biodiversity, etc. [64]. 
The fact that the control group had the smaller mean diameter of particles under 2 $\mathrm{mm}$ (Fig. 3-7a) and smaller mass fraction of grains that were larger than $2 \mathrm{~mm}$ (Fig. 3-8) indicates that the mean grain size was smaller in the control group over all. Since there were no apparent mechanisms related to the operation of the PV panel that would cause the disparity in the mean grain sizes of the two experimental groups, the more plausible mechanism behind this disparity was determined to have taken place during the construction of the PV arrays. A likely cause behind the predominance of the larger particles in the treatment is the erosion of the finer particles following the disturbance in the topsoil and removal of the native vegetation during the construction process. Soil erosion in PV facilities [7], soil erosion during construction [65,66], and water erosion due to lack of vegetative cover [67] had all been thoroughly documented. However, a study comparing the distribution of grain sizes among four different sites (an undisturbed site, a co-located site with conventional PV installation process, a co-located site with the minimal topsoil disturbance and vegetation removal, and a standalone PV site with no vegetation) need to be conducted in order to test whether the initial topsoil disturbance and vegetation removal promotes loss of finer grain through erosion.

The significance of the correlation between the tilt direction of the PV panels and the concentration of soil moisture was that the PV panels can be strategically oriented for the benefit of the co-location of the PV array with crops: the panels could be oriented in a manner that would direct rain drops to or away from a location immediately adjacent to the PV array, depending on the irrigation requirement of the crop. For instance, it has been suggested that cultivating drought-resistant crops such as aloe under the edges of solar panels to be irrigated by water used to wash the PV panels would suppress dust emissions, which in turn would reduce the dust cover on the panels $[14,29,68]$. Conversely, some 
tropical crops such as patchouli (Pogostemon cablin) that require protection from excessive rainfall at the seedling stage could be placed under the PV panels during the seedling stage to be planted on the side of the lower edge of the PV array in their adult stage to receive more water. Thus, understanding of the timing and the direction of the rainfall is crucial to placing and orienting the PV panels need to create the desired rainfall distribution. The rate of discharge from the edge of the tilted panel could be modeled using the height of the PV panel, the dimensions of the panel, the incident angle of the rain drops, and the precipitation rate.

While shading from the PV panels may inhibit the growth of the crops, the light that reach the soil surface was unaffected in its quantity. In addition, heterogeneity of light distribution on the ground was found to decrease with height [15]. Furthermore, an increase in biomass and nutritive quality have been demonstrated in selective crops grown under the shade $[69,70]$, speaking to the plausibility of the co-location design.

The fact that the treatment did not have significantly higher UHC than the control despite the larger overall particle size implies that the construction methods and the type and frequency of human activity in the accessible parts of a photovoltaic array have just as much impact on the hydraulic conductivity of the soil at the base of a PV array: compaction decreases the pore diameter of the soil, which means reduced storage capacity and a change in pore size distribution towards the narrower pores [60]. The reduction in pore space is detrimental not only for the hydraulic conductivity, but also for the maintenance of soil atmosphere composition of oxygen and carbon dioxide that is necessary for plant growth [60]. Reduction of the soil compaction in the PV array and its environmental consequences may depend on a technological solution that would allow installation of utility-scale PV without heavy machinery. Another area with room for improvement with regards to soil 
compaction would be to minimize the need for human activity in the maintenance of the PV array via automation of the maintenance process.

\subsection{Conclusions}

Our results from the NWTC test site indicate that solar arrays can have significant impacts on hydrologic, physical, and nutritional properties of the underlying soil. The soil nutrient levels and soil grain size are on average lower in the revegetated solar PV plot. Lower grain size in the revegetated solar plot may be caused partial stripping of the topsoil during the construction stage, which would also result in lower soil nutrient levels in the revegetated solar plots than those in the undisturbed plot. In particular, the spatial heterogeneity of soil moisture was greater in the solar plot before and after the precipitation event.

The heterogeneity in soil moisture patterns indicate the effect of panel orientation on precipitation redistribution by solar panels, indicating that solar arrays could be used to manipulate soil moisture distribution, an important aspect for evaluating the potential to co-locate crops with solar infrastructures or "agrivoltaics". Further, these on-site environmental consequences should be quantified and modeled for site preservation, evaluating the long-term impact of onsite management strategies, and for optimizing resource (e.g. soil moisture, nutrients, sunlight) availability for co-location natural vegetation/crops with photovoltaic arrays.

In considering the importance of the findings, it should be noted that this study is limited to the drylands of Colorado. The significance of the soil moisture heterogeneity may be magnified in more arid climates where the spatial distribution of soil moisture is likely to have a larger impact on plant growth. Furthermore, this study is limited to one 
solar facility where vegetation was re-established following the construction of the solar infrastructure. In general, re-vegetated solar facilities not standard practice and there are no re-vegetated facilities with a history as long as this site. Despite these limitations, the preliminary findings suggest that the heterogeneity in the soil moisture results from PVC construction and persists despite revegetation even after seven years. Therefore, the study should be taken as a guide for future studies on co-located PV-vegetation facilities. A longterm sensor-based study measuring fine-scale spatio-temporal changes in the soil hydrology is the next step. 


\title{
CHAPTER 4
}

COMBINED LAND USE OF SOLAR INFRASTRUCTURE AND AGRICULTURE FOR SOCIOECONOMIC AND ENVIRONMENTAL CO-BENEFITS IN INDONESIA

\begin{abstract}
To meet the electricity demand of its growing population, Indonesia is resolved to increase overall generation capacity and achieve 100\% electrification rate across the country by 2050 . Distributed diesel generation is often favored over grid extension as a means of satisfying electricity demand in remote islands in Indonesia, but off-grid or microgrid solar photovoltaics (PV) has been evaluated to partially or fully replace the diesel generation. While solar photovoltaics provides reduces carbon emissions, the construction and the subsequent land occupation of the PV may negatively impact the land's ability to perform ecosystem services. Agrivoltaics is an emerging strategy to mitigate PV's land and water footprint by combining PV electricity generation with agriculture into a single land use. While this strategy has been determined to be plausible in temperate and arid climates, it has not been studied in the tropics like that of Indonesia.
\end{abstract}

To quantify environmental and economic benefits of the agrivoltaic scheme in Indonesia, a life cycle assessment (LCA) models were developed for hypothetical land uses: a photovoltaic land use, a cash crop (patchouli) cultivation land use, and an agrivoltaic land use with a full density of the cash crop and low density of the photovoltaics. The model inputs for the patchouli component were obtained from detailed field interviews with fragrance industry professionals in West Java, Indonesia. The outputs of the LCA models were primary energy requirement per year per hectare, carbon dioxide equivalent emissions per year per hectare, and net present value of each land use ( 5 ha) after 30 years. The LCA 
models were implemented in $\mathrm{R}$ for sensitivity analysis and Monte Carlo simulations $(\mathrm{N}=$ $10,000)$.

The LCA shows that the PV component of the agrivoltaics design can offset the carbon footprint and the energy requirement of the agricultural component. Furthermore, the revenue from the agricultural component of the agrivoltaic system offset the cost of the PV component, which was costly compared to average earnings of a small-scale farmer on top of being poorly subsidized. The most of the annual carbon emissions of the patchouli component were from the wood-burning during the processing of raw materials, and possible retrofitting of the processor with solar energy source would reduce the carbon footprint of the agricultural component.

Breakdown of the electricity produced from full-density solar PV land use demonstrated less than half of the generated electricity could satisfy the demand of 350 rural households with modern amenities such as a refrigerator and a TV on top of public and commercial activities such as a hospital, a school, and coffee milling. The size of surplus electricity from a full-density solar PV land use indicated that the number of PV modules per hectare could be reduced to less than half and still support municipal and commercial electricity demands. 


\subsection{Introduction}

The lack of access to modern energy services remains a roadblock to promoting economic growth that will expand employment and provide a means of overcoming poverty in the rural areas of developing countries [71]. As of 2017, more than 1 billion people around the world still lack electricity access and the resulting restrictions on economic growth remain a predominant problem in rural areas of developing countries $[71,72]$. In recognition of this barrier, the UN has adopted rural electrification as an important part of the 2030 Agenda for Sustainable Development [71].

Conventionally, electrification is achieved through extension of a grid from a centralized source [73]. However, the high initial investment cost of grid extension due to geographic barriers, the increased cost of generation, transmission and distribution losses, and the costly centralized management system for small loads make grid extension into rural communities an unattractive and sometimes impossible option [73-75]. Furthermore, rural electrification in developing countries should include steps to mitigate climate change by selecting a low-carbon energy sources since these countries will be among the most vulnerable to its impacts $[71,73]$. For these reasons, it is imperative to consider off-grid or mini-grid options that utilize low-cost, renewable sources for rural electrification of developing countries.

Indonesia is a particularly useful test case as only $80 \%$ of its 258 million people have access to electricity in 2013. It faces further challenges in providing electricity access to the remaining $20 \%[11,18]$ since this population is widely spread across the archipelago. For example, although the Java-Bali system has the highest electrification rates with Jakarta having $99.99 \%$, an island such as Papua in the outer ring islands has just $36.41 \%$ electrification [11]. The main difficulty with the electrification of these area is that most of 
these islands are located far from fuel sources and that the average energy consumption per capita is very low, rendering the cost of grid infrastructure too expensive and the return on investment too small $[11,73]$. As a result, most of these areas have become reliant on offgrid diesel-powered generation $[11,12,73]$.

While diesel generation provides reliability, scalability, availability and low upfront cost, it has a very high operating costs because of its dependence on diesel fuel $[12,73]$. Furthermore, the cost of diesel fuel is even higher in the rural areas where their distance from the distribution centers result in high cost of transportation [12]. Like most developing countries, Indonesia is highly vulnerable to the effects of the climate change as most of its population and economic activities are concentrated in coastal areas $[11,76]$. Thus, Indonesia needs to increase its rural electrification rates while reducing the carbon emissions from electricity generation [73]. While diesel-powered generation is a useful offgrid option for the rural areas, its high carbon emission and the aforementioned financial drawbacks necessitates that the rural electrification projects shift away from their dependence on diesel fuel to renewable energy sources.

For Indonesia, solar photovoltaics (PV) is one of the most competitive renewable options for rural electrification projects. While Indonesia has high technical potential for hydropower and geothermal, they are not suitable for rural electrification since their energy sources are either far from their demand centers or there are environmental regulations that obstruct the development of these energy sources [11]. In addition, development of these resources is often best-suited to larger scale power plants, which entail large upfront costs [77]. In contrast, the high technical potential of solar energy can be more easily used as sunlight in this region is a mostly ubiquitous energy source. As a tropical country, Indonesia has a high average daily insolation, generally ranging from 4.5 to $5.1 \mathrm{kWhm}^{-2}$ 
[11,21]. Although solar PV generation is maximized during direct illumination, it can effectively generate useful electricity when diffusely illuminated during cloudy conditions, thus enabling effective deployment in the tropical Indonesian climate [34].

From a financial perspective, factory production of PV allows for economies of scale $[7,16]$, and the advances in the technology are rapidly and continuously decreasing cost of solar PV generation [31,78,79]. Even though PV system costs are relatively high compared to more developed markets [11], the levelized cost of electricity (LCOE) from standalone PV generation have been estimated to be cheaper than the LCOE from dieselpowered generation in 25 out of 32 provinces of Indonesia, and the continued decrease of the price of PV systems and the expected increase of the price of diesel is expected to turn PV into the cheaper option in the remaining seven provinces as well [80]. As of 2017, PV projects totaling over $240 \mathrm{MW}$ in installed capacity have been announced [81], and the Indonesia government aims to increase the installed capacity of PV to $6.4 \mathrm{GW}$ by 2025 [82]. It has been suggested that the PV capacity will reach $9.3 \mathrm{GW}$ in a business-as-usual scenario, but that it could reach $47.2 \mathrm{GW}$ in the most optimistic scenario [82].

For all their advantages, however, PV technologies have their shortcomings. First, PV technologies are not free of emissions, even though their emissions are far lower than those of conventional fuels [83]. Moreover, large-scale PV facilities require large tracts of land to be cleared of vegetation and leveled, raising concerns over possible impacts on the surrounding ecology and/or agricultural activities [16,25,52]. Relative to arid-climate installations, the land impact of the large-scale PV facilities may be magnified in Indonesia, where more than half of the land area is forested and nearly two-thirds of the non-forested area is occupied by agricultural activities [18], leaving little room for much else. Conventional deployment of community-scale PV facilities may take up valuable 
agricultural lands or require additional deforestation, which may be counter-productive to the development of rural economy or adversely impact the local environment and the effort to reduce carbon emissions. Despite these obstacles, there are several strategies that may effectively mitigate adverse impacts of solar PV land use or disturbance of agriculturally or ecologically important land, including use of: (1) already developed environments (e.g. rooftop); (2) salt-affected or contaminated lands ill-suited for agriculture or forestry; (3) floating PV modules on reservoirs [7,41].

Another emerging option is co-location of PV array with agriculture to increase the land-use efficiency $[8,14-16]$. In the co-location scheme, crops (ranging from cash crops and biofuels to native vegetation) are placed under or around the PV modules [16]. Some of the expected benefits of co-locating PV with vegetation is continuous income stream for farmers, additional employment opportunities at the solar facility for the management of the crops, electrification of rural areas, and electricity to power additional entrepreneurial activities, such as locally processing agricultural products [8]. From an environmental conservation perspective, the co-location design may also increase the water-use efficiency by recycling the water used for cleaning the PV modules and dust suppression for irrigation of the crops, suppress erosion from PV facilities, and increase the PV efficiency via cooling of the PV modules $[14,16]$. The challenge to optimizing these socioeconomic and environmental co-benefits is choosing the right approach to co-location.

The three most common approaches to PV-vegetation co-location include energycentric, vegetation-centric, and a hybridization approach [16]: The energy-centric approach maximizes the output of PV-generated electricity, and adheres to the standard practices of solar installation and operation as closely as possible while producing biomass under and around the solar installation [16]. This approach is suitable for pre-existing large-scale solar 
facilities or in areas with large tracts of land designated or available for solar development [16]. In contrast, the vegetation-centric approach maximizes biomass production while minimizing the impact on the vegetation management activities by the PV [16]. This vegetation-centric approach is better suited for areas that are land-constrained or areas that are established or designated for agricultural activities since it does not interfere with established agricultural or land management practices [16]. Lastly, the hybridization approach is a balanced approach that gives equal weight to both energy production and biomass production [16]. In this approach, both biomass production and electricity production are likely to be lower than they would be without co-location, but the landowner may benefit from the diversified income [16]. This hybrid approach can be employed in all areas where either energy-centric or vegetation-centric approaches are viable [16].

As an example of energy-centric co-location, a portion of 1.1-MW PV array at the National Wind Technology Center of National Renewable Energy Laboratory in Colorado was revegetated with native plants to a degree sufficient for erosion control [16,52]. In another example, a feasibility study on the co-location of aloe plants with a large-scale, grid-tied PV facility in the drylands in the northwestern region of India determined that the design co-location would generate more income than either standalone aloe cultivation or standalone PV generation [14]. Also, a pilot study of tomato cultivation under PV arrays in Arizona demonstrated higher tomato yield and longer growing season [84].

However, these studies were performed in drylands, and the challenges in optimizing co-location schemes in these locations are different from those in Indonesia. As a tropical archipelago, rain is abundant but the land is limited as nearly two-thirds of nonforested area suitable for development is occupied by agricultural activities [18]. 
Furthermore, the cost of PV generations remains high due to the low number of experts on PV among local government authorities, enterprises, and financial institutions, and less-developed markets and local supply chains [11]. Although some financial incentives are available in the form of feed-in tariff (FiT) for solar PV [11], they would not be available for off-grid systems. As a result, the financial burden of initial investment and upkeep of the co-located system in an off-grid PV system would fall on the landowner and his ability to arrange a wholesale of generated electricity. The land constraints and the high initial cost of a large-scale PV facility render the energy-centric co-location approach improbable. Therefore, vegetation-centric co-location approach is more suitable for the rural electrification of Indonesia.

A component to designing an economically viable PV-crop co-location is the selecting an ideal crop. A crop ideal for co-location with PV should be short as not to shade the PV modules, shade-tolerant plant so that it can survive the canopy created by the PV modules, and require little to no mechanization in its cultivation to minimize the disturbance of the PV array with heavy machinery. Furthermore, the crop should be one that is already cultivated locally and should have established processing facilities and marketing channels [14]. In Indonesia, one of the candidates for the ideal crop is patchouli.

Patchouli (Pogostemon cablin) is a perennial herb that is native to South and Southeast Asia [85]. It is prized for its aromatic essential oil that is used extensively in the fragrance industry to fix scent-emitting substances into products such as soaps, perfumes, detergents, and toothpastes [85]. Patchouli is extensively cultivated and processed in Indonesia on several different islands, and approximately $90 \%$ of world's patchouli oil is produced from Indonesia [86,87]. Therefore, the logistical suitability for patchouli cultivation and oil production for the purpose of co-location is robust. Patchouli plants are 
shade-tolerant and are generally short enough (1 to $1.2 \mathrm{~m})[85,88]$ to be placed under or around PV modules without obstructing the them. Furthermore, planting and harvest of patchouli are best done by hand [87], which minimizes the use of heavy machinery that could potentially disturb the PV arrays.

In summary, patchouli plants meet both the logistic and the physiological requirements for co-location with the PV, and the vegetation-centric co-location may be a low-carbon option for rural electrification that is more affordable than the standard diesel generation. The co-located system may also provide secondary benefits such as extra employment in the maintenance of the PV infrastructure, utilization of the electricity from the co-located system for agricultural product processing or the operation of public infrastructures, such as hospitals, schools, or municipal water pumps.

To verify these benefits, a careful life cycle analyses (LCA) of four separate land uses - standalone PV generation, patchouli cultivation and essential oil processing, PVpatchouli co-location with full PV module density, and PV-patchouli co-location with half PV module density - were performed for lifetime energy input, output, carbon footprint, cash flow, and net present value (NPV). Then, the possible uses of the surplus energy from the system were compared to electricity demand profiles of an energy demand scenario of a typical village in rural Indonesia that is based on field investigations and interviews by Blum [12] to examine the capacity of the co-located system to support commercial and public infrastructures.

\subsection{Methods}

The determination of feasibility and the estimation of expected benefits of colocation of solar power generation with crop production were based on Life Cycle Analysis (LCA) of the following land use scenarios: a standalone solar photovoltaic system, 
standalone cultivation of an "ideal" co-location crop and co-located solar PV-crop system. LCA is a concept that is often used to determine the viability of new technologies in which environmental footprints, such as energy and greenhouse gas emissions and water and land usage throughout the life cycle of a technology is estimated $[14,36,89]$. The LCA model will be implemented in R to perform sensitivity and uncertainty analysis.

Even though an LCA modeling framework has been developed for a utility-scale solar PV installation with aloe vera cultivation and gel production in desert areas of Northwestern India [14], the performance of a similar co-location strategy has not been modeled for a tropical climate, such as that of Indonesia.

The LCA was performed for the following land use scenarios: a standalone solar PV system, cultivation of $P$. cablin Benth. and extraction of its essential oil, and a colocated PV-patchouli system. The output of LCA of solar PV consisted of land use, energy production, energy consumption, and greenhouse gas (GHG) emissions/offsets. Water usage was not considered for any scenario because, unlike in other parts of the world, the performance of the co-located system in the tropics would not likely be constrained by the availability of water. The constraint for the input values of the LCA were derived from existing studies, or initially derived from existing studies then supplemented by locationspecific data collected during field visits in the summer of 2017. All outputs were expressed per hectare to address the land-use efficiency of each scenario. The LCA model was implemented in R (R. ver. 3.2.4). A schematic diagram summarizing the methods is presented in Fig. 4-1. 


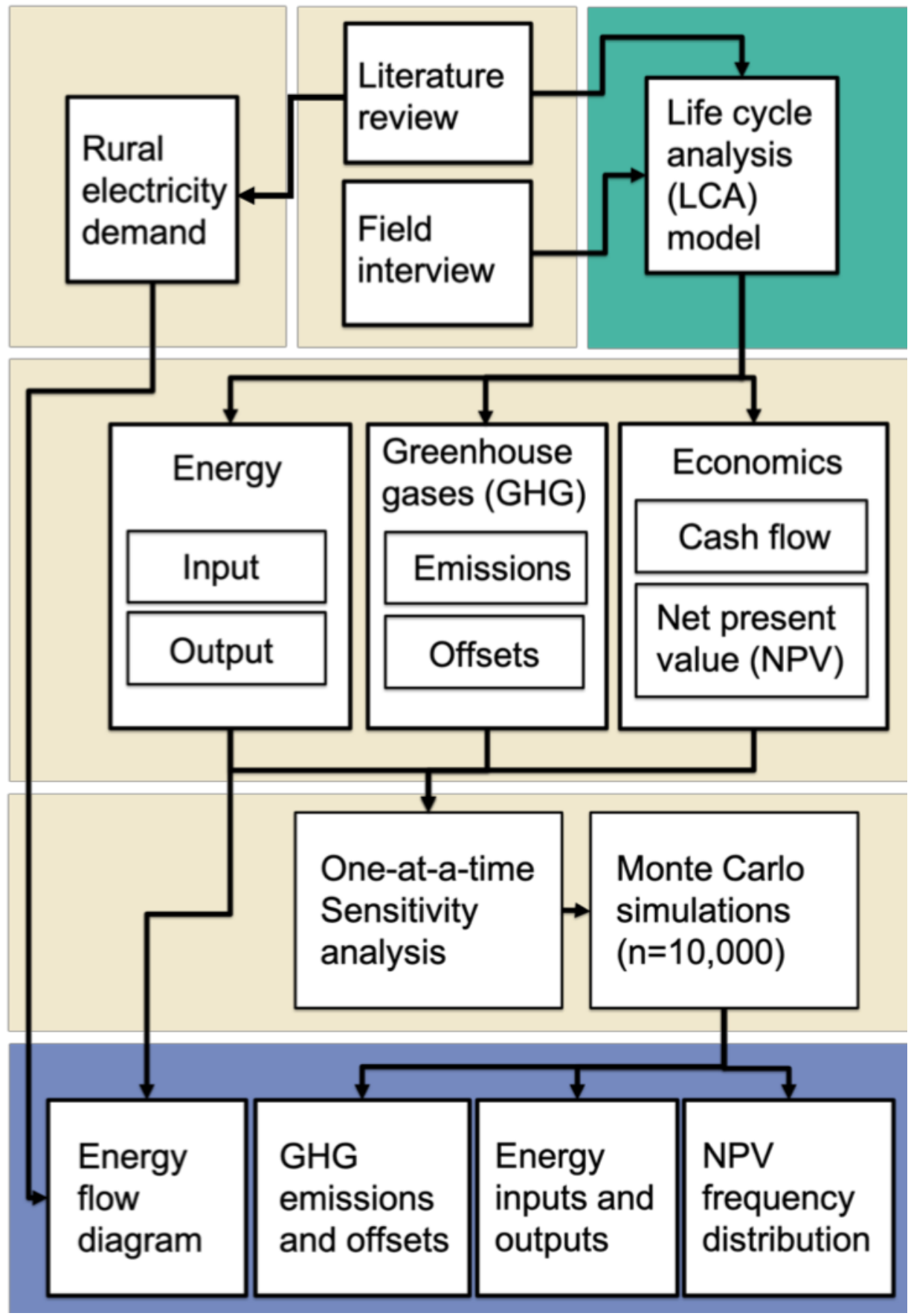

Figure 4-1. A schematic diagram summarizing the methodology of this study. The LCA model is highlighted in green, and the outputs of the sensitivity analysis and the Monte Carlo simulation is highlighted in blue. 


\subsubsection{Life Cycle Analysis of Solar Photovoltaics}

For the purpose of co-location with crops, only solar PV was considered because PV is the dominant solar technology for current and proposed solar power installations [14]. The energy components of LCA for solar PV include (1) embodied energy (energy required for all stages of manufacturing of goods)[90] of module and balance of system (BOS) components, (2) operation, (3) end-of-life (EOL) stage (decommission and treatment/disposal), and (4) transport of PV modules and BOS components. For the LCA, multi-crystalline silicon PV technology was chosen over other PV technologies because of its high performance in a tropical setting, such as that of Indonesia [83,91]. The outputs of the LCA model of the solar PV system were lifetime GHG emission, land usage, energy intake, and energy output. Additionally, the lifetime GHG emission from the solar PV system was compared to the GHG emissions from using diesel generation or grid to obtain the same amount of energy as would be generated by the solar PV system over its lifetime. Then, all the outputs were divided over the system's assumed lifetime of 20 years to express them in a per-hectare-per-year basis $\left(\mathrm{ha}^{-1} \mathrm{yr}^{-1}\right)$.

\subsubsection{Lifetime Energy Input and Output of Solar Photovoltaics}

Lifetime energy input and output of the solar PV system was first expressed in kWh per hectare $\left(\mathrm{kWh} \mathrm{ha}^{-1}\right)$. Lifetime energy input to the solar PV system is a sum of energy required for (1) manufacturing of the module and BOS components such as module frames, mounting structures, grid connectors, batteries, and concrete that are required for installing the module; (2) operation of the module; (3) end-of-life (EOL) stage; and (4) transport of PV modules and BOS components, and was expressed as follows: 


$$
\begin{aligned}
& \text { Lifetime energy input }\left(k W h h a^{-1}\right) \\
& \qquad \begin{array}{l}
\text { Module \& } B O S_{E}\left(k W h h a^{-1}\right) \\
+\operatorname{Use}_{E}\left(k W h h a^{-1}\right)+E O L_{E}\left(k W h h a^{-1}\right) \\
+\operatorname{Transport}_{E}\left(k W h h a^{-1}\right)
\end{array}
\end{aligned}
$$

Then, the lifetime energy input was divided by the lifetime of the system ( 20 years) to yield annual energy input:

$$
\begin{aligned}
& \text { Annual energy input }\left(k W h h^{-1}\right) \\
& \qquad=\frac{\text { Lifetime energy input }\left(k W h h a^{-1}\right)}{\text { Lifetime of the PV system }(\text { years })}
\end{aligned}
$$

Energy input during the manufacturing of the module and the BOS components was considered to be the following:

$$
\begin{aligned}
& \text { Module \& } B_{O} S_{E}\left(\mathrm{kWh} \mathrm{ha}^{-1}\right) \\
& =(\text { Raw material acquisition }(\mathrm{kWh}) \\
& + \text { material processing }(\mathrm{kWh}) \\
& + \text { manu facturing of } P V \text { modules and BOS }(\mathrm{kWh}) \\
& + \text { construction and installation }(\mathrm{kWh})) \\
& \times \text { number of modules \& BOS per unit area }\left(\mathrm{ha}^{-1}\right)
\end{aligned}
$$

Energy input for the operation of the system was considered to be the following:

$$
\begin{aligned}
& \text { Use } e_{E}\left(k W h h^{-1}\right) \\
& =(\text { auxiliary electricity demand }(k W h) \\
& + \text { cleaning of panels }(k W h)+\text { maintenance }(k W h) \\
& + \text { repair and replacement }(k W h)) \\
& \times \text { number of modules \& BOS per unit area }\left(h a^{-1}\right)
\end{aligned}
$$

Energy input during the EOL of the system

$$
\begin{aligned}
& \text { EOL } L_{E}\left(k W h h^{-1}\right) \\
& =(\text { Deconstruction\&dismantling }(k W h) \\
& + \text { waste processing }(k W h)+\text { disposal }(k W h)) \\
& \times \text { number of modules \&BOS per unit area }\left(h a^{-1}\right)
\end{aligned}
$$

Finally, energy input for transportation was calculated as follows: 
Transport $_{E}\left(k W h \mathrm{ha}^{-1}\right)$

$=($ distance from production center to power plant $(\mathrm{km})$

+ distance from power plant to disposal site $(\mathrm{km})$ )

$\times$ energy expenditure per unit distance of transporting a PV module anc 6) $\times$ number of modules \& BOS per unit area $\left(\mathrm{ha}^{-1}\right)$

Annual energy output from the solar PV was calculated as follows:

$$
\begin{aligned}
& \text { Annual energy output ( } k W h y^{-1} h a^{-1} \text { ) } \\
& =\text { annual insolation }\left(\mathrm{kWh} \mathrm{m}^{-2}\right) \\
& \times \text { module area }\left(\mathrm{m}^{2} \text { module }{ }^{-1}\right) \\
& \times \text { number of modules (modules } \mathrm{ha}^{-1} \text { ) } \\
& \times \text { conversion efficiency (unitless) } \\
& \times \text { performance ratio (unitless) }
\end{aligned}
$$

Then, lifetime energy output from the solar PV was calculated as follows:

$$
\begin{aligned}
& \text { Lifetime energy output }\left(k W h \mathrm{ka}^{-1}\right) \\
& \quad \begin{array}{l}
\quad \text { annual energy output }\left(k W h \mathrm{yr}^{-1} h \mathrm{a}^{-1}\right) \\
\quad \times \operatorname{lifetime}(\mathrm{yr})
\end{array}
\end{aligned}
$$

\subsubsection{Lifetime GHG emissions and offsets of solar photovoltaics}

Lifetime GHG emission of solar PV included embodied GHG emission of solar PV, GHG emission of use, GHG emission during EOL stage, and GHG emission from transportation of materials and PV components, and was expressed as follows:

$$
\begin{aligned}
& \text { Lifetime } \mathrm{GHG} \text { emissions }\left(\mathrm{Mg}_{\mathrm{CO}_{2} e} \mathrm{ha^{-1 }}\right) \\
& =\text { Module \& } \mathrm{BOS}_{\mathrm{GHG}}\left(\mathrm{Mg}_{\mathrm{CO}_{2} e} h \mathrm{~h}^{-1}\right) \\
& +U_{S e_{G H G}}\left(M_{\mathrm{CO}_{2} e} h a^{-1}\right) \\
& +E O L_{G H G}\left(M_{\mathrm{CO}_{2} e} h a^{-1}\right)
\end{aligned}
$$

Then, the lifetime GHG emission of solar PV is divided over the 30 years (lifetime of 30 years) to calculate annual GHG emission of the solar PV system:

$$
\begin{aligned}
& \text { Annual GHG emissions }\left(\mathrm{Mg}_{\mathrm{CO}_{2} \text { e }} \mathrm{ha}^{-1}\right) \\
& =\frac{\text { Lifetime } \mathrm{GHG} \text { emissions }\left(\mathrm{Mg}_{\mathrm{CO}_{2} \text { e }} h \mathrm{ha}^{-1}\right)}{\text { Lifetime of the PV system (years) }}
\end{aligned}
$$

The components of the embodied GHG emission of module and balance of system 
(BOS) are as follows:

$$
\begin{aligned}
& \text { Module \& } \mathrm{BOS}_{\mathrm{GHG}_{\mathrm{H}}}\left(\mathrm{Mg}_{\mathrm{CO}_{2} \text { e }} \mathrm{ha}^{-1}\right) \\
& =\left(\text { Raw material acquisition }\left(\mathrm{Mg}_{\mathrm{CO}_{2} e}\right)\right. \\
& + \text { material processing }\left(\mathrm{Mg}_{\mathrm{CO}_{2} e}\right) \\
& + \text { manufacturing of } \mathrm{PV} \text { modules and } \mathrm{BOS}\left(\mathrm{Mg}_{\mathrm{CO}_{2} e}\right) \\
& \left.+ \text { construction and installation }\left(\mathrm{Mg}_{\mathrm{CO}_{2} e}\right)\right) \\
& \times \text { number of modules \& BOS per unit area }\left(\mathrm{ha}^{-1}\right)
\end{aligned}
$$

The components of the GHG emission of use are as follows:

$$
\begin{aligned}
& U_{S e_{G H G}}\left(M_{C_{2} e} h a^{-1}\right) \\
& =\left(\text { auxiliary electricity demand }\left(\mathrm{Mg}_{\mathrm{CO}_{2} e}\right)\right. \\
& + \text { cleaning of panels }\left(\mathrm{Mg}_{\mathrm{CO}_{2} e}\right) \\
& + \text { maintenance }\left(\mathrm{Mg}_{\mathrm{CO}_{2} e}\right) \\
& \left.+ \text { repair and repair and replacement }\left(\mathrm{Mg}_{\mathrm{CO}_{2} e}\right)\right) \\
& \times \text { number of modules \& BOS per unit area }\left(\mathrm{ha}^{-1}\right)
\end{aligned}
$$

The components of GHG emission during the EOL stage (decommissioning, treatment and disposal) are as follows:

$$
\begin{aligned}
& E O L_{G H G}\left(\mathrm{Mg}_{\mathrm{CO}_{2} e} \mathrm{ha}^{-1}\right) \\
& =\left(\text { Deconstruction \&dismantling }\left(\mathrm{Mg}_{\mathrm{CO}_{2} e}\right)\right. \\
& + \text { waste processing }\left(\mathrm{Mg}_{\mathrm{CO}_{2} e}\right) \\
& \left.+ \text { disposal }\left(\mathrm{Mg}_{\mathrm{CO}_{2} e}\right)\right) \\
& \times \text { number of modules \& BOS per unit area }\left(\mathrm{ha}^{-1}\right)
\end{aligned}
$$

GHG emission of transport is calculated based on the travel distance of PV module and BOS as follows:

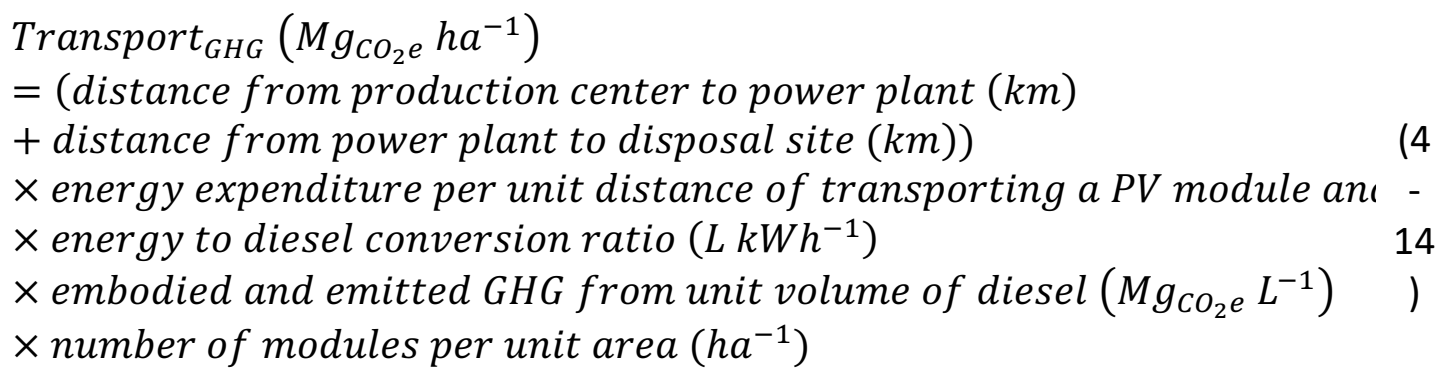


As with the transport component of energy input, energy expenditure per unit distance and emission per unit energy is contingent upon the mode of transport. Additionally, the distance from production center to power plant and the distance from power plant to disposal site will also have a significant impact on the net emission.

GHG offsets by the solar PV against diesel was calculated as follows:

$$
\begin{aligned}
& \text { GHG off set diesel }\left(\mathrm{Mg}_{\mathrm{CO}_{2} e} \mathrm{ha}^{-1}\right) \\
& \text { = Lifetime } \mathrm{GHG} \text { emissions }\left(\mathrm{Mg}_{\mathrm{CO}_{2} e} \mathrm{ha}^{-1}\right) \\
& \text { - lifetime energy output }\left(k W h h a^{-1}\right) \\
& \times \text { emission } \text { factor }_{\text {diesel }}\left(\mathrm{Mg}_{\mathrm{CO}_{2} e} \mathrm{kWh}^{-1}\right)
\end{aligned}
$$

GHG offsets by the solar PV against the Indonesian grid was calculated as follows:

$$
\begin{aligned}
& \text { GHG offset }{ }_{\text {grid }}\left(\mathrm{Mg}_{\mathrm{CO}_{2} \text { e }} \mathrm{ha}^{-1}\right) \\
& =\text { Lifetime } \mathrm{GHG} \text { emissions }\left(\mathrm{Mg}_{\mathrm{CO}_{2} \text { e }} \mathrm{ha}^{-1}\right) \\
& \text { - lifetime energy output }\left(\mathrm{kWh} \mathrm{ha}^{-1}\right) \\
& \times \text { emission factor } \text { grid }_{\text {frid }}\left(\mathrm{Mg}_{\mathrm{CO}_{2} \text { e }} \mathrm{kWh}^{-1}\right)
\end{aligned}
$$

Assumptions for the LCA of the PV component of the standalone PV and colocated land-uses are listed in Table 4-1 with sources.

\subsubsection{Life Cycle Analysis of Patchouli Cultivation and Essential Oils Extraction}

Patchouli grows well under warm and humid climate, and it can be grown successfully under a heavy and evenly distributed rainfall, from 150 to $300 \mathrm{~cm} / \mathrm{yr}$ [92]. As the most exported of all Indonesian essential oils by volume, annual global consumption of patchouli oil is about 2000 metric tons [93], and the majority of the world's patchouli oil is from Indonesia [93-95]. The methods and criteria for the life cycle analysis of patchouli are adopted from the life cycle analysis (LCA) methodology described in Yan et al (2011) and Ravi et al (2016), which is based on the production pathway used in the tequila industry in Mexico and the aloe-solar colocation in India respectively. The data 
required for the life cycle analysis of patchouli cultivation and extraction of its essential oil were collected from literature $[85,88,93-98]$ and site visits in Indonesia. The components of the LCA of patchouli and their respective inputs are listed in Table 4-2 with their sources.

Patchouli has an economic lifetime of 1.5 to 2 years, but the lifetime of 2 years was chosen to simply the annual calculation of energy inputs, GHG emissions, and cash flow components. A longer lifetime with a consistent harvest interval would lead to more harvests in the lifetime of each crop cycle, and overestimation of economic viability is expected. With the patchouli lifetime at two years, the project period of 30 years contains 15 patchouli life cycles.

Rather than being planted as seeds in the field, patchouli has a better chance of survival when planted as a seedling under a shade for the first 1.5 months of its life, so it is often first grown in a polybag under a partially shaded hut for 1.5 months before being planted in the field [87]. However, this study does not consider the plant nursery stage. Instead, it is assumed that the seedlings are planted directly into the field with a survival rate of 0.9 at the time of maturity, which occurs at approximately seven months from the time of planting [87]. The first harvest occurs at maturity, and then subsequent harvests occur every 3-4 months the previous harvest. Each plant yields approximately $1 \mathrm{~kg}$ of fresh mass per harvest, which shrinks down to $0.25 \mathrm{~kg}$ after being dried in the shade for several days [102]. Shade-drying on racks or on other flat surface with proper ventilation is recommended for maximal oil yield, as heating or direct sunlight may vaporize the oil from the dry mass $[92,102,103]$. 
Table 4-1. Assumptions made for the LCA of standalone solar photovoltaics

\begin{tabular}{|c|c|c|c|c|c|c|}
\hline \multirow{2}{*}{$\begin{array}{c}\text { Variable } \\
\text { Module } \\
\text { density } \\
\end{array}$} & \multirow{2}{*}{$\begin{array}{l}\begin{array}{l}\text { Base } \\
\text { case }\end{array} \\
3500 \\
\end{array}$} & \multirow{2}{*}{$\begin{array}{c}\text { Unit } \\
\text { modules ha-1 }\end{array}$} & \multicolumn{2}{|c|}{$\begin{array}{c}\text { Range used } \\
\text { for Monte } \\
\text { Carlo } \\
\end{array}$} & \multirow[t]{2}{*}{ Note } & \multirow{2}{*}{$\begin{array}{c}\text { Source } \\
{[14]}\end{array}$} \\
\hline & & & 2500 & 3500 & & \\
\hline $\begin{array}{l}\text { Nameplate } \\
\text { capacity }\end{array}$ & 120 & $\mathrm{~W}_{\mathrm{p}}$ module $^{-1}$ & & & & [14] \\
\hline $\begin{array}{c}\text { Average } \\
\text { annual } \\
\text { irradiation }\end{array}$ & 1825 & & 1752 & 1898 & & [80] \\
\hline $\begin{array}{c}\text { PV } \\
\text { efficiency }\end{array}$ & 0.15 & & 0.14 & 0.16 & $\begin{array}{l}\text { Range } \\
\text { user- } \\
\text { defined }\end{array}$ & [14] \\
\hline $\begin{array}{c}\text { Performance } \\
\text { ratio }\end{array}$ & 0.75 & & 0.7 & 0.8 & & $\begin{array}{l}\text { User- } \\
\text { defined }\end{array}$ \\
\hline $\begin{array}{l}\text { Embodied } \\
\text { energy of } \\
\text { PV + BOS }\end{array}$ & 8.7036 & $\mathrm{kWh} \mathrm{W}_{\mathrm{p}}^{-1}$ & - & - & - & [99] \\
\hline $\begin{array}{l}\text { GHG per } \\
\text { output }\end{array}$ & 0.045 & $\mathrm{~kg}_{\mathrm{CO} 2 \mathrm{eq}} \mathrm{kWh}^{-1}$ & - & - & - & [83] \\
\hline $\begin{array}{c}\text { GHG } \\
\text { emission of } \\
\text { diesel } \\
\text { electricity }\end{array}$ & 1.27 & $\mathrm{~kg}_{\mathrm{CO} 2 \mathrm{eq}} \mathrm{kWh}^{-1}$ & - & - & - & {$[100]$} \\
\hline $\begin{array}{l}\text { Grid } \\
\text { emission } \\
\text { factor }\end{array}$ & 0.782 & $\begin{array}{l}\mathrm{Kg}_{\mathrm{CO} 2} \\
\mathrm{kWh}^{-1}\end{array}$ & - & - & $\begin{array}{c}\text { For } \\
\text { Jamali } \\
\text { grids, } \\
\text { Ex-post }\end{array}$ & {$[101]$} \\
\hline
\end{tabular}


Table 4-2. Assumptions made for the inputs for the LCA of patchouli cultivation and distillation

\begin{tabular}{|c|c|c|c|c|c|c|}
\hline \multirow{2}{*}{$\begin{array}{c}\text { Variable } \\
\begin{array}{c}\text { Project } \\
\text { period }\end{array}\end{array}$} & \multirow{2}{*}{$\begin{array}{c}\begin{array}{c}\text { Base } \\
\text { case }\end{array} \\
30\end{array}$} & \multirow{2}{*}{$\begin{array}{l}\text { Unit } \\
\text { years }\end{array}$} & \multicolumn{2}{|c|}{$\begin{array}{l}\text { Range used } \\
\text { for Monte } \\
\text { Carlo }\end{array}$} & \multirow{2}{*}{$\begin{array}{c}\text { Note } \\
\begin{array}{c}\text { Lifetime of } \\
\text { PV }\end{array}\end{array}$} & \multirow{2}{*}{$\begin{array}{c}\text { Source } \\
\text { User- } \\
\text { defined }\end{array}$} \\
\hline & & & - & - & & \\
\hline $\begin{array}{l}\text { Land } \\
\text { occupied } \\
\text { by the } \\
\text { project }\end{array}$ & 5 & hectare & - & - & 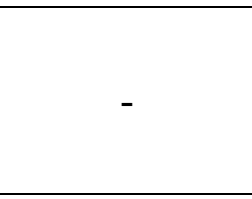 & $\begin{array}{l}\text { User- } \\
\text { defined }\end{array}$ \\
\hline \multicolumn{7}{|c|}{ Cultivation stage } \\
\hline Total Area & 10 & $\mathrm{Ha}$ & - & - & - & $\begin{array}{c}\text { Field } \\
\text { interview }\end{array}$ \\
\hline $\begin{array}{l}\text { Number } \\
\text { of } \\
\text { plants/ha }\end{array}$ & 20000 & plants $\mathrm{ha}^{-1}$ & $\begin{array}{c}17,50 \\
0\end{array}$ & 22,500 & - & $\begin{array}{c}\text { Field } \\
\text { interview }\end{array}$ \\
\hline $\begin{array}{l}\text { Crop } \\
\text { survival } \\
\text { rate }\end{array}$ & 0.9 & - & - & - & - & $\begin{array}{c}\text { Field } \\
\text { interview }\end{array}$ \\
\hline $\begin{array}{l}\text { Economic } \\
\text { life }\end{array}$ & 24 & months & - & - & - & $\begin{array}{c}\text { Field } \\
\text { interview }\end{array}$ \\
\hline $\begin{array}{l}\text { Months to } \\
\text { maturity }\end{array}$ & 7 & months & - & - & - & $\begin{array}{c}\text { Field } \\
\text { interview }\end{array}$ \\
\hline $\begin{array}{l}\text { Wet yield } \\
\text { per plant }\end{array}$ & 1 & $\begin{array}{l}\text { Kg plant }^{-1} \\
\text { harvest }^{-1}\end{array}$ & 0.75 & 1 & - & $\begin{array}{c}\text { Field } \\
\text { interview }\end{array}$ \\
\hline $\begin{array}{l}\text { Dry yield } \\
\text { as a } \\
\text { fraction of } \\
\text { fresh yield }\end{array}$ & 0.25 & - & - & - & - & \\
\hline $\begin{array}{c}\text { Initial N } \\
\text { dose }\end{array}$ & 200 & $\mathrm{~kg} \mathrm{ha}^{-1}$ & - & - & $\begin{array}{c}\text { Applied } \\
\text { before or } \\
\text { with planting }\end{array}$ & $\begin{array}{c}\text { Field } \\
\text { interview }\end{array}$ \\
\hline $\begin{array}{l}\text { Initial P } \\
\text { dose }\end{array}$ & 100 & $\mathrm{~kg} \mathrm{ha}^{-1}$ & - & - & $\begin{array}{c}\text { Applied } \\
\text { before or } \\
\text { with planting }\end{array}$ & $\begin{array}{c}\text { Field } \\
\text { interview }\end{array}$ \\
\hline $\begin{array}{c}\text { Initial K } \\
\text { dose }\end{array}$ & 150 & $\mathrm{Kg} \mathrm{ha}^{-1}$ & - & - & $\begin{array}{c}\text { Applied } \\
\text { before or } \\
\text { with planting }\end{array}$ & $\begin{array}{c}\text { Field } \\
\text { interview }\end{array}$ \\
\hline $\begin{array}{c}\text { Initial } \\
\text { manure } \\
\text { dose }\end{array}$ & 1 & $\mathrm{Kg}_{\text {plant }}{ }^{-1}$ & - & - & $\begin{array}{c}\text { Applied } \\
\text { before or } \\
\text { with planting }\end{array}$ & $\begin{array}{l}\text { Field } \\
\text { interview }\end{array}$ \\
\hline $\begin{array}{l}\text { Subseque } \\
\text { nt } \mathrm{N} \text { dose }\end{array}$ & 100 & $\mathrm{~kg} \mathrm{ha}^{-1}$ & - & - & $\begin{array}{c}\text { Applied just } \\
\text { after a } \\
\text { harvest }\end{array}$ & $\begin{array}{c}\text { Field } \\
\text { interview }\end{array}$ \\
\hline
\end{tabular}


Table 4-2. (continued)

\begin{tabular}{|c|c|c|c|c|c|c|}
\hline Variable & $\begin{array}{l}\text { Base } \\
\text { case }\end{array}$ & Unit & & sed & Note & Source \\
\hline $\begin{array}{l}\text { Subseque } \\
\text { nt } P \text { dose }\end{array}$ & 50 & $\mathrm{~kg} \mathrm{ha}^{-1}$ & - & - & $\begin{array}{c}\text { Applied just } \\
\text { after a } \\
\text { harvest }\end{array}$ & $\begin{array}{l}\text { Field } \\
\text { interview }\end{array}$ \\
\hline $\begin{array}{l}\text { Subseque } \\
\text { nt K dose }\end{array}$ & 100 & $\mathrm{~kg} \mathrm{ha}^{-1}$ & - & - & $\begin{array}{c}\text { Applied just } \\
\text { after a } \\
\text { harvest }\end{array}$ & $\begin{array}{c}\text { Field } \\
\text { interview }\end{array}$ \\
\hline $\begin{array}{l}\text { Subseque } \\
\text { nt manure } \\
\text { dose }\end{array}$ & 1 & $\mathrm{~kg} /$ plant & - & - & $\begin{array}{c}\text { Applied just } \\
\text { after a } \\
\text { harvest }\end{array}$ & $\begin{array}{c}\text { Field } \\
\text { interview }\end{array}$ \\
\hline $\begin{array}{l}\text { Travel } \\
\text { distance } \\
\text { from } \\
\text { fertilizer } \\
\text { plant to } \\
\text { farm } \\
\end{array}$ & 100 & $\mathrm{~km}$ & - & - & 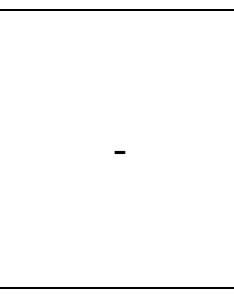 & $\begin{array}{l}\text { User- } \\
\text { defined }\end{array}$ \\
\hline $\begin{array}{c}\text { Truck } \\
\text { diesel use } \\
\text { efficiency }\end{array}$ & 52.4 & $\mathrm{~km} \mathrm{Mg} \mathrm{L} \mathrm{L}^{-1}$ & - & - & - & [104] \\
\hline $\begin{array}{l}\text { Embodied } \\
\text { energy of } \\
\text { diesel }\end{array}$ & 1.15 & $\begin{array}{c}\mathrm{kWh} \\
\mathrm{kWh}_{\text {diesel }}{ }^{-1}\end{array}$ & - & - & - & [104] \\
\hline $\begin{array}{l}\text { Energy } \\
\text { content of } \\
\text { diesel }\end{array}$ & 10.5 & $\mathrm{kWh} \mathrm{L}^{-1}$ & - & - & $\begin{array}{c}\text { converted } \\
\text { from the } \\
\text { original } \\
\text { value of } 37.8 \\
\text { MJ/L }\end{array}$ & [104] \\
\hline $\begin{array}{l}\text { Embodied } \\
\text { energy of } \\
\text { nitrogen }\end{array}$ & 15.8 & $\mathrm{kWh} \mathrm{kg}^{-1}$ & - & - & 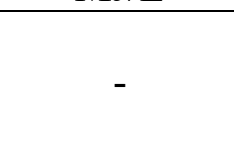 & [104] \\
\hline $\begin{array}{l}\text { Embodied } \\
\text { energy of } \\
\text { phosphate }\end{array}$ & 2.6 & $\mathrm{kWh} \mathrm{kg}^{-1}$ & - & - & - & {$[104]$} \\
\hline $\begin{array}{l}\text { Embodied } \\
\text { energy of } \\
\text { potash }\end{array}$ & 1.9 & $\mathrm{kWh} \mathrm{kg}^{-1}$ & - & - & - & [104] \\
\hline $\begin{array}{c}\text { GHG } \\
\text { emission } \\
\text { of } \\
\text { nitrogen }\end{array}$ & 11 & $\underset{\mathrm{kg}^{-1}}{\mathrm{~kg}_{\mathrm{CO} 2 \mathrm{eq}}}$ & - & - & - & [104] \\
\hline $\begin{array}{c}\text { GHG } \\
\text { emission } \\
\text { of } \\
\text { phosphate }\end{array}$ & 1.61 & $\underset{\mathrm{kg}^{-1}}{\mathrm{~kg}_{\mathrm{CO} 2 \mathrm{eq}}}$ & - & - & - & [104] \\
\hline
\end{tabular}


Table 4-2. (continued)

\begin{tabular}{|c|c|c|c|c|c|c|}
\hline \multirow{2}{*}{$\begin{array}{c}\text { Variable } \\
\begin{array}{c}\text { GHG } \\
\text { emission } \\
\text { of potash }\end{array}\end{array}$} & \multirow{2}{*}{$\begin{array}{l}\begin{array}{c}\text { Base } \\
\text { case }\end{array} \\
0.71\end{array}$} & \multirow{2}{*}{$\begin{array}{c}\text { Unit } \\
\begin{array}{c}\mathrm{kg}_{\mathrm{CO} 2 \mathrm{eq}} \\
\mathrm{kg}^{-1}\end{array}\end{array}$} & \multicolumn{2}{|c|}{$\begin{array}{l}\text { Range used } \\
\text { for Monte } \\
\text { Carlo } \\
\end{array}$} & \multirow{2}{*}{$\begin{array}{c}\text { Note } \\
-\end{array}$} & \multirow{2}{*}{$\begin{array}{r}\text { Source } \\
{[104]}\end{array}$} \\
\hline & & & - & - & & \\
\hline $\begin{array}{c}\text { GHG } \\
\text { emission } \\
\text { of diesel }\end{array}$ & 3.25 & $\mathrm{~kg}_{\mathrm{CO} 2 \mathrm{eq}} \mathrm{L}^{-1}$ & - & - & $\begin{array}{c}\text { calculated } \\
\text { from } 0.086 \\
\mathrm{~kg}_{\mathrm{CO} 2 \mathrm{eq}} / \mathrm{MJ} \\
\text { of diesel } \\
\text { energy } \\
\text { content from } \\
\text { the original } \\
\text { source }\end{array}$ & {$[104]$} \\
\hline \multicolumn{7}{|c|}{ Harvest and transport stage } \\
\hline $\begin{array}{c}\text { Travel } \\
\text { distance } \\
\text { from farm } \\
\text { to } \\
\text { distillation } \\
\text { plant }\end{array}$ & 1 & $\mathrm{~kg}$ & - & - & - & $\begin{array}{l}\text { User- } \\
\text { defined }\end{array}$ \\
\hline \multicolumn{7}{|c|}{ Distillation stage } \\
\hline $\begin{array}{l}\text { Building } \\
\text { area }\end{array}$ & 100 & $\mathrm{~m}^{2}$ & - & - & - & $\begin{array}{c}\text { User- } \\
\text { defined }\end{array}$ \\
\hline $\begin{array}{l}\text { Building } \\
\text { lifetime }\end{array}$ & 10 & years & - & - & - & $\begin{array}{c}\text { User- } \\
\text { defined }\end{array}$ \\
\hline $\begin{array}{c}\text { Distillatio } \\
\text { n unit } \\
\text { lifetime }\end{array}$ & 10 & years & - & - & - & $\begin{array}{l}\text { Field } \\
\text { interview }\end{array}$ \\
\hline $\begin{array}{c}\text { Max. } \\
\text { number of } \\
\text { distillation } \\
\text { s per year }\end{array}$ & 220 & $\begin{array}{l}\text { distillation } \\
\mathrm{s} \mathrm{yr}^{-1}\end{array}$ & - & - & - & $\begin{array}{c}\text { Field } \\
\text { interview }\end{array}$ \\
\hline $\begin{array}{l}\text { distillation } \\
\text { capacity }\end{array}$ & 250 & $\begin{array}{c}\mathrm{kg}_{\text {dry yield }} \\
\text { distillation } \\
-1\end{array}$ & - & - & - & $\begin{array}{l}\text { Field } \\
\text { interview }\end{array}$ \\
\hline $\begin{array}{l}\text { dry yield } \\
\text { to oil } \\
\text { conversio } \\
\text { n rate }\end{array}$ & 0.028 & $\mathrm{~kg} \mathrm{~kg}_{\text {yield }}^{-1}$ & 0.025 & 0.03 & - & $\begin{array}{c}\text { Field } \\
\text { interview }\end{array}$ \\
\hline
\end{tabular}


Table 4-2. (continued)

\begin{tabular}{|c|c|c|c|c|c|c|}
\hline Variable & $\begin{array}{l}\text { Base } \\
\text { case }\end{array}$ & Unit & & & Note & Source \\
\hline $\begin{array}{l}\text { Firewood } \\
\text { required } \\
\text { for } \\
\text { distillation }\end{array}$ & 117 & $\underset{-1}{\mathrm{~kg}}$ & - & - & $\begin{array}{c}\text { Calculated } \\
\text { from payload } \\
\text { of common } \\
\text { trucks used } \\
\text { by firewood } \\
\text { vendors }\end{array}$ & $\begin{array}{l}\text { Field } \\
\text { interview }\end{array}$ \\
\hline $\begin{array}{l}\text { Embodied } \\
\text { energy of } \\
\text { building } \\
\text { per area }\end{array}$ & 227.12 & $\mathrm{kWh} \mathrm{m}^{2}{ }^{2}$ & - & - & 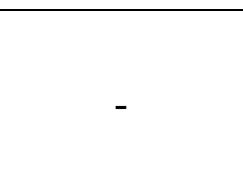 & [105] \\
\hline $\begin{array}{c}\text { Embodied } \\
\text { energy of } \\
\text { distillation } \\
\text { unit }\end{array}$ & 2900 & kWh unit ${ }^{-1}$ & - & - & $\begin{array}{l}\text { Calculated } \\
\text { from the } \\
\text { mass of steel } \\
\text { required to } \\
\text { manufacture } \\
\text { a distillation } \\
\text { unit }\end{array}$ & - \\
\hline $\begin{array}{c}\text { Effective } \\
\text { heat of } \\
\text { combustio } \\
n \text { of } \\
\text { firewood }\end{array}$ & 4.086 & $\mathrm{kWh} \mathrm{kg}^{-1}$ & - & - & $\begin{array}{c}\text { Of } \\
\text { Paraserianth } \\
\text { es falcataria }\end{array}$ & [106] \\
\hline $\begin{array}{c}\text { GHG } \\
\text { emission } \\
\text { of } \\
\text { building }\end{array}$ & 178 & $\mathrm{~kg}_{2} \underset{2 \mathrm{eq}}{\mathrm{C}} \mathrm{m}^{-}$ & - & - & - & [105] \\
\hline $\begin{array}{l}\text { GHG } \\
\text { emission } \\
\text { of } \\
\text { distillation } \\
\text { unit }\end{array}$ & 1000 & $\begin{array}{c}\mathrm{kg}_{\mathrm{CO} 2 \mathrm{eq}} \\
\text { unit }^{-1}\end{array}$ & - & - & $\begin{array}{l}\text { Calculated } \\
\text { from } \\
\text { embodied } \\
\text { energy of } \\
\text { stainless steel }\end{array}$ & \\
\hline $\begin{array}{c}\text { GHG } \\
\text { emission } \\
\text { of } \\
\text { firewood }\end{array}$ & 1.02 & $\mathrm{~kg}_{\mathrm{CO} 2} \mathrm{~kg}^{-1}$ & - & - & - & [106] \\
\hline
\end{tabular}


The level of mechanization is very low for patchouli cultivation as the leaves and stems need to be harvested by hand using scissors [87,102], and diesel consumption only occurs during the transport of materials, such as fertilizers and dry yields. For the calculation of diesel consumption, both the travel distance between the fertilizer factory to farm and between the farm to the distillation unit has been set arbitrarily at $100 \mathrm{~km}$ and 1 $\mathrm{km}$, respectively.

Pesticide application was not considered for the model, as good agricultural practices of patchouli and the industry professionals advise against the use of pesticides in patchouli cultivation $[87,102]$. The application of manure and agrochemicals are dependent on the productivity of the soil, but this study used the following application dosage and schedule (Table 4-3):

A simple crop rotation with yardlong beans (two years of patchouli and two years of yardlong beans) was also considered as recommended as a remedy to the decrease in patchouli yield caused by autotoxicity of patchouli and soil nutrient depletion [102,107]. Yardlong beans were also assumed to be fit for crop rotation with patchouli based on their ability to fix nitrogen and thrive in the tropics [108]. For the crop rotation, patchouli was cultivated in one half of the available land while yardlong beans were cultivated in the other half of the land. At the end of the two-year period, yardlong beans would be cultivated on the first half of the land previously occupied by patchouli, and patchouli would be cultivated on the other half of the land previously occupied by yardlong beans.

Energy inputs and GHG emissions from the components of patchouli cultivation that last longer than the economic lifetime of patchouli (building and distillation unit) were first calculated on their lifetime-basis then divided by their lifetime to determine annual energy inputs and outputs. 
Table 4-3. Fertilizer application schedule

\begin{tabular}{|c|c|c|}
\hline Fertilizer type & $\begin{array}{c}\text { Initial dose (applied } \\
\mathbf{1 - 2} \text { weeks before } \\
\text { planting) }\end{array}$ & $\begin{array}{c}\text { Subsequent dose } \\
\text { (applied after each } \\
\text { harvest) }\end{array}$ \\
\hline $\mathrm{N}\left(\mathrm{kg} \mathrm{ha}^{-1}\right)$ & 200 & 100 \\
\hline $\mathrm{P}\left(\mathrm{kg} \mathrm{ha}^{-1}\right)$ & 100 & 50 \\
\hline $\mathrm{K}\left(\mathrm{kg} \mathrm{ha}^{-1}\right)$ & 150 & 100 \\
\hline $\begin{array}{c}\text { Manure or organic } \\
\text { fertilizer }\left(\mathrm{kg} \mathrm{plant}^{-1}\right)\end{array}$ & 1 & 1 \\
\hline
\end{tabular}

\subsubsection{Lifetime Energy Input of Patchouli Cultivation and Essential Oils Extraction}

The sum of energy spent on the cultivation of and the extraction of essential oil from patchouli was calculated on the basis of patchouli's economic life, which was two years, and were broken down as the following:

$$
\begin{aligned}
& \text { Input energy }_{i} \\
&=\text { Patchouli cultivation }_{e} \\
&+ \text { Harvest \& Transport } \\
&+ \text { Essential oil distillation } \\
&
\end{aligned}
$$

where Patchouli cultivation $_{e}$ represents the energy requirement of cultivating patchouli, Harvest \& Transport $_{e}$ the energy requirement for harvesting patchouli and transporting it, and Essential oil distillation $n_{e}$ the energy usage of producing patchouli essential oil through steam distillation.

Without farm machinery usage, the components of energy input into patchouli cultivation are as follows:

$$
\begin{aligned}
& \text { Patchouli cultivation }_{e} \\
& \quad=\text { Cultivation diesel energy } \\
& + \text { Embodied agrochemical energy, }
\end{aligned}
$$

where Cultivation diesel energy is the embodied energy of diesel used to transport the agrochemicals to the farm and Embodied agrochemical energy is the energy used for producing the agrochemicals. Cultivation diesel energy was calculated as following: 


\section{Cultivation diesel energy}

$$
\begin{aligned}
& =\frac{(\text { Agrochem.Year } 1+\text { Agrochem.Year } 2) \times \text { Factory to farm }}{\text { Truck efficiency }} \\
& \times \text { Diesel energy content } \times \text { embodied energy of diesel, }
\end{aligned}
$$

where Agrochem. Year 1 and Agrochem. Year 2 are the sum of the masses of organic fertilizer, N, P, and K used for the first and the second year of patchouli's lifetime, respectively. Factory to farm is the distance between the agrochemical factory and the farm, and Truck efficiency is the diesel use efficiency of the truck in $\mathrm{km} \mathrm{Mg} \mathrm{L}^{-1}$. Diesel energy content is the energy content in a liter of diesel expressed as $\mathrm{kWh} \mathrm{L}^{-1}$, and Embodied energy of diesel is the embodied energy of diesel per unit energy from diesel, which is unitless.

Embodied agrochemical energy was calculated as follows:

$$
\begin{aligned}
& \text { Embodied agrochemical energy } \\
& \qquad N_{e} \times\left(N_{1}+N_{2}\right)+P_{e} \times\left(P_{1}+P_{2}\right) \\
& \quad+K_{e} \times\left(K_{1}+K_{2}\right),
\end{aligned}
$$

where $N_{e}, P_{e}$, and $K_{e}$ are the embodied energy of N, P, and K. $N_{1}, P_{l}$, and $K_{l}$ are the mass of $\mathrm{N}, \mathrm{P}$, and $\mathrm{K}$ used in the first year of harvest in $\mathrm{kg} \mathrm{ha}^{-1}$, and $N_{2}, P_{2}$, and $K_{2}$ are the $\mathrm{N}, \mathrm{P}$, and $\mathrm{K}$ used in the second year of harvest in $\mathrm{kg} \mathrm{ha}^{-1}$.

Ideally, patchouli is harvested manually then air-dried under a shade before being transported to the distillation plant to be put through a steam distillation process. Therefore, the energy of harvest and transportation of yield, Harvest \& Transporte, consisted only of the diesel usage for transporting the dried yield to the distillation plant, and was calculated as follows:

$$
\begin{aligned}
& \text { Harvest \& Transport } \text { Tr }_{e} \\
& =\frac{(\text { dry yield } 1+\text { dry yield } 2) \times \text { Farm to distillation plant }}{\text { Truck efficiency }} \\
& \times \text { Diesel energy content } \times \text { embodied energy of diesel, }
\end{aligned}
$$


where dry yield 1 and dry yield 2 were the mass of dry yield per hectare, Farm to distillation plant the user-defined distance between the farm and the distillation plant in $\mathrm{km}$. The dry yield for the first year was calculated as follows:

$$
\begin{aligned}
\text { dry yield } 1= & \left(\frac{12 \text { mos }- \text { maturity }}{\text { harvest interval }}+1\right) \times \text { plants } \\
& \times \text { fresh yield } \times \text { dry to fresh ratio, }
\end{aligned}
$$

where maturity is the number of months required for the crop to reach maturity, harvest interval is the interval between harvests in months expressed in mo harvest ${ }^{-1}$, and plants is the number of plants per hectare, fresh yield is the wet yield from each plant per harvest in kg plant ${ }^{-1}$ harvest $^{-1}$. Finally, dry to fresh ratio is the coefficient of mass loss of the yield after air-drying, which is unitless. The dry yield for the second year was calculated as

$$
\begin{aligned}
& \text { dry yield } 2 \\
& =\left(\frac{24 \text { mos }- \text { maturity }- \text { harvest interval } \times\left(\frac{12 \text { mos }- \text { maturity }}{\text { harvest interval }}\right)}{\text { harvest interval }}\right. \\
& +1) \times \text { plants } \times \text { fresh yield } \times \text { dry to fresh ratio. }
\end{aligned}
$$

Lastly, Essential oil distillation $e_{e}$ was calculated as follows:

$$
\begin{aligned}
& \text { Essential oil distillation }_{e} \\
& \qquad \begin{array}{l}
=\text { Building }_{e}+{\text { Distillation } \text { unit }_{e}} \\
+ \text { Firewood }_{e}+\text { Electricity }_{e}
\end{array}
\end{aligned}
$$

where Building $_{e}$ was the embodied energy of constructing a building with an area of 100 $\mathrm{m}^{2}$ and a lifetime of ten years, and Distillation unite is the embodied energy of the distillation unit with a lifetime of ten years. Both the embodied energy of the building and the distillation unit were first divided by five to normalize to the lifetime of patchouli (two years), and then multiplied by the usage ratio, which was the portion of the maximum annual distillation capacity that was utilized by the dry patchouli yield from a hectare of 


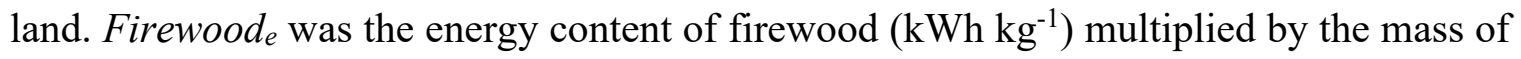
firewood used $(\mathrm{kg})$ for the distillation process over the lifetime of patchouli, and Electricity $_{e}$ was the usage of electricity at the distillation plant over two years that was calculated from the approximate cost of monthly electricity usage at the distillation plant.

\subsubsection{Lifetime GHG Emissions of Patchouli Cultivation and Essential Oils Extraction}

As with the energy input, the sum of GHG emissions from the cultivation of and the extraction of essential oil from patchouli was calculated on the basis of patchouli's economic life, which was two years, and were broken down as the following:

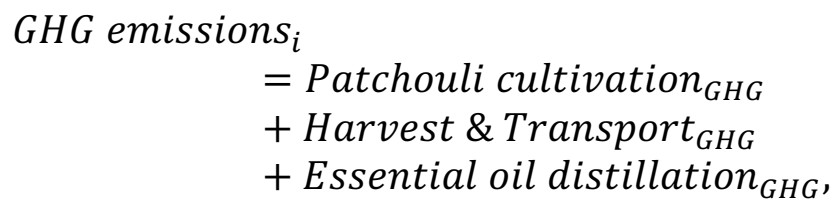

where Patchouli cultivation ${ }_{G H G}$ represents the GHG emission of cultivating patchouli, Harvest \& Transport $_{G H G}$ the emission of harvesting patchouli and transporting it, and Essential oil distillation $_{G H G}$ the $\mathrm{GHG}$ emission of producing patchouli essential oil through steam distillation.

The GHG emission of patchouli cultivation is calculated as follows:

$$
\begin{aligned}
\text { Patchouli cultivation }_{G H G} \\
\quad=\text { Cultivation diesel } G H G \\
+ \text { Embodied agrochemical GHG }
\end{aligned}
$$

where Cultivation diesel GHG was the GHG emissions from diesel used to transport the agrochemicals to the farm and Embodied agrochemical $G H G$ was the GHG emissions from producing the agrochemicals. Cultivation diesel $G H G$ was calculated as following:

$$
\begin{aligned}
& \text { Cultivation diesel GHG } \\
& =\frac{(\text { Agrochem.Year } 1+\text { Agrochem.Year } 2) \times \text { Factory to farm }}{\text { Truck efficiency }} \\
& \times \text { Diesel GHG, }
\end{aligned}
$$


where Diesel GHG is the GHG emission from combusting a liter of diesel expressed as $\operatorname{kg}_{\mathrm{CO} 2 \mathrm{eq}} \cdot \mathrm{L}^{-1}$.

Embodied agrochemical $G H G$ was calculated as follows:

$$
\begin{aligned}
& \text { Embodied agrochemical GHG } \\
& =N_{G H G} \times\left(N_{1}+N_{2}\right) \\
& +P_{G H G} \times\left(P_{1}+P_{2}\right) \\
& +K_{G H G} \times\left(K_{1}+K_{2}\right) \text {, }
\end{aligned}
$$

where $N_{G H G}, P_{G H G}$, and $K_{G H G}$ are the embodied GHG emissions of $\mathrm{N}, \mathrm{P}$, and $\mathrm{K}$ in $\mathrm{kg}_{\mathrm{CO} 2 \mathrm{eq}}$ $\mathrm{kg}^{-1}$.

As with the energy required for the harvest and transport stage, the GHG emissions from the harvest and transport stage consisted only of the diesel used for transporting the dry yield from farm to the distillation plant, and was calculated as follows:

$$
\begin{aligned}
& \text { Harvest \& Transport }{ }_{G H G} \\
& =\frac{(\text { dry yield } 1+\text { dry yield } 2) \times \text { Farm to distillation plant }}{\text { Truck efficiency }} \\
& \times \text { Diesel GHG. }
\end{aligned}
$$

Lastly, GHG emission of the essential oil production process Essential oil distillation $_{G H G}$ was calculated as follows:

$$
\begin{aligned}
& \text { Essential oil distillation }_{G H G} \\
&=\text { Building }_{G H G} \\
&+ \text { Distillation unit }_{G H G} \\
&+ \text { Firewood }_{G H G} \\
&+ \text { Electricity }_{e} \\
& \times \text { Grid emission factor }
\end{aligned}
$$

where Building ${ }_{G H G}$ was the embodied GHG emission of building with an area of $100 \mathrm{~m}^{2}$ and a lifetime of ten years, and Distillation unit ${ }_{G H G}$ the embodied GHG emission of the 
distillation unit with a lifetime of ten years. Both the embodied GHG emission of the building and the distillation unit were first divided by five to normalize to the lifetime of patchouli (two years), and then multiplied by the usage ratio, which was the portion of the maximum annual distillation capacity that was utilized by the dry patchouli yield from a hectare of land. Firewood ${ }_{G H G}$ was the carbon dioxide emission from combustion of firewood for the distillation process over the lifetime of patchouli, and Grid emission factor was the grid emission factor in $\mathrm{kg}_{\mathrm{CO} 2 \mathrm{eq}} \mathrm{kWh}^{-1}$.

\subsubsection{LCA of Co-Located PV-Patchouli Land Use}

For the LCA of co-located land use, the module density was assumed to be a third of the full module density in the standalone PV land use. The modules density of the colocated land use was determined to be a third of the full module density because the annual energy output of a hectare of the standalone PV land use was determined to be roughly three times the rural electricity demand scenario described in Blum et al [12]. The relative yield per plant was assumed to be $0.78(0.73-0.83)$ of the full yield of patchouli land use, based on the predicted relative yield by Dupraz, Marrou, Talbot et al. for relative yields under full module density (0.73) and half module density $(0.83)$ [15]. Finally, the number of plants per hectare were also reduced to 0.9 of the plant density in patchouli land use, which was done to account for the area taken up by base of system (BOS) for PV, as described by Dupraz, Marrou, Talbot et al [15].

\subsubsection{Sensitivity Analysis and Monte Carlo Simulation}

Sensitivity analysis (one-at-a-time local sensitivity analysis) was performed for the standalone PV land use and the patchouli land use. For the patchouli land use, 50\% and 
$150 \%$ of the base case model inputs were used. The base case values are shown in the Tables 4-1, 4-2, and 4-4, and the results of the sensitivity analysis is shown in Table 4-5 and 4-6. The variables that showed more than $10 \%$ difference from the base case results in the negative or the positive direction were chosen for the Monte Carlo simulations. However, some variables that caused more than $10 \%$ difference were excluded from the Monte Carlo simulation at the author's discretion if any variation in the variable was deemed unrealistic. The range of variables that were used for the Monte Carlo simulations are listed next to the base case values of the respective variables in Tables 4-1, 4-2, and 4-

\section{4.}

The Monte Carlo simulation were performed to obtain ranges for the outputs of the life cycle energy inputs/outputs, GHG emissions/offsets, and NPV of the two single land uses and the two co-located land uses. The simulation was iterated 10,000 times so that the results would be comparable to Ravi's study on co-location of PV with aloe cultivation, which also used 10,000 iterations for its Monte Carlo simulation [14]. The input values for each iteration was drawn randomly from a triangular distribution of the input variables. All the inputs varied for single land uses are also varied for the co-located land use. The results of the Monte Carlo simulations are shown in Fig. 4-2 and 4-3, and Table 4-7. 


\subsubsection{Economic analysis}

The NPV of all four land uses were calculated over a 30 -year period using annualized cash flow. The solar PV analyses assumed a default module density of 3500 modules per hectare, and a range of 2500 to 3500 modules ha $^{-1}$ was used for the standalone PV land use. The system was assumed to be off-grid, and thus the sole source of income in the standalone PV land use was assumed to be wholesale of electricity at the base case price of 2743 Indonesian Rupiah (IDR) per kWh, which was the typical value of feed-in tariff in Jamali. Base case performance ratio was $75 \%$. The pricing of the off-grid PV array and the EPC margin were based on a quote for a $200-\mathrm{m}^{2}$ ground-mounted solar array from a solar company in West Java (http://www.teknologihijau.co.id) on November $8^{\text {th }}, 2017$.

The agricultural component of the economic analysis assumes a full crop density for patchouli of 20,000 (17,500 - 22,500) plants per hectare. Patchouli's economic life of two years is repeated 15 times over the project period. Based on age to maturity and harvest intervals of patchouli, harvest occurs twice in the first year and three times in the second year, totaling five harvests over two years. This model assumes that all five hectares of patchouli and all five hectares of yardlong beans are harvested on the same schedule. All economic assumptions are listed in Table 4-5. 
Table 4-4. Assumptions made for the economic analysis of standalone PV, patchouli cultivation and distillation, and co-located land uses.

\begin{tabular}{|c|c|c|c|c|c|c|}
\hline \multirow{2}{*}{$\begin{array}{c}\text { Variable } \\
\begin{array}{c}\text { Land lease } \\
\text { cost }\end{array}\end{array}$} & \multirow{2}{*}{$\begin{array}{c}\text { Base case } \\
2000000\end{array}$} & \multirow{2}{*}{$\begin{array}{c}\text { Unit } \\
\begin{array}{c}\text { IDR ha- } \\
\mathrm{yr}^{-1}\end{array}\end{array}$} & \multicolumn{2}{|c|}{$\begin{array}{c}\text { Range used } \\
\text { for Monte } \\
\text { Carlo } \\
\end{array}$} & \multirow{2}{*}{$\begin{array}{c}\text { Note } \\
-\end{array}$} & \multirow{2}{*}{$\begin{array}{c}\text { Source } \\
{[109]}\end{array}$} \\
\hline & & & - & - & & \\
\hline $\begin{array}{c}\text { Seedling } \\
\text { cost }\end{array}$ & 1500 & $\begin{array}{c}\text { IDR } \\
\text { seedling }^{-1}\end{array}$ & - & - & - & $\begin{array}{c}\text { Field } \\
\text { interview }\end{array}$ \\
\hline $\begin{array}{c}\text { Nitrogen } \\
\text { price }\end{array}$ & 5000 & IDR kg-1 & - & - & - & $\begin{array}{c}\text { Field } \\
\text { interview }\end{array}$ \\
\hline $\begin{array}{c}\text { Phosphate } \\
\text { price }\end{array}$ & 5000 & IDR kg-1 & - & - & - & $\begin{array}{c}\text { Field } \\
\text { interview }\end{array}$ \\
\hline Potash price & 6000 & IDR $\mathrm{kg}^{-1}$ & - & - & - & $\begin{array}{c}\text { Field } \\
\text { interview }\end{array}$ \\
\hline $\begin{array}{c}\text { Manure } \\
\text { price }\end{array}$ & 500 & IDR kg-1 & - & - & - & $\begin{array}{c}\text { Field } \\
\text { interview }\end{array}$ \\
\hline Diesel price & 14300 & $\mathrm{IDR} \mathrm{L}^{-1}$ & 14300 & 19500 & $\begin{array}{l}\text { Calculated } \\
\text { from [80], } \\
2015, \text { which } \\
\text { was given in } \\
\text { USD }\end{array}$ & \\
\hline $\begin{array}{l}\text { Monthly } \\
\text { electricity } \\
\text { cost }\end{array}$ & 650000 & $\begin{array}{c}\text { IDR } \\
\text { month }^{-1}\end{array}$ & - & - & 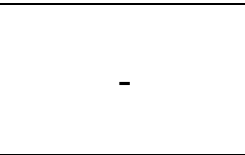 & $\begin{array}{c}\text { Field } \\
\text { interview }\end{array}$ \\
\hline $\begin{array}{c}\text { Firewood } \\
\text { price }\end{array}$ & 607 & IDR kg-1 & - & - & - & $\begin{array}{c}\text { Field } \\
\text { interview }\end{array}$ \\
\hline $\begin{array}{c}\text { Labor cost } \\
\text { of } \\
\text { cultivation }\end{array}$ & 1000000 & $\begin{array}{c}\text { IDR } \\
\text { person }^{-1} \\
\text { month }^{-1}\end{array}$ & - & - & - & $\begin{array}{c}\text { Field } \\
\text { interview }\end{array}$ \\
\hline $\begin{array}{l}\text { Labor cost } \\
\text { of } \\
\text { distillation }\end{array}$ & 1000000 & $\begin{array}{l}\text { I IDR } \\
\text { person }^{-1} \\
\text { month }^{-1}\end{array}$ & - & - & - & $\begin{array}{c}\text { Field } \\
\text { interview }\end{array}$ \\
\hline $\begin{array}{l}\text { People } \\
\text { required for } \\
\text { cultivation }\end{array}$ & 35 & $\begin{array}{l}\text { people } \\
\text { month }^{-1}\end{array}$ & - & - & - & [109] \\
\hline $\begin{array}{l}\text { People } \\
\text { required for } \\
\text { distillation }\end{array}$ & 3 & $\begin{array}{l}\text { people } \\
\text { month }^{-1}\end{array}$ & - & - & - & $\begin{array}{c}\text { Field } \\
\text { interview }\end{array}$ \\
\hline $\begin{array}{c}\text { Cost of } \\
\text { distillation } \\
\text { unit }\end{array}$ & 150000000 & IDR $_{\text {unit }}{ }^{-1}$ & - & - & $\begin{array}{c}\text { Occurs at the } \\
\text { beginning } \\
\text { and then } \\
\text { every ten } \\
\text { years }\end{array}$ & $\begin{array}{c}\text { Field } \\
\text { interview }\end{array}$ \\
\hline
\end{tabular}


Table 4-4. (continued)

\begin{tabular}{|c|c|c|c|c|c|c|}
\hline Variable & Base case & Unit & $\begin{array}{r}\text { Rang } \\
\text { for } 1 \\
\mathrm{C}\end{array}$ & $\begin{array}{l}\text { used } \\
\text { onte } \\
\text { lo } \\
\end{array}$ & Note & Source \\
\hline $\begin{array}{l}\text { Building } \\
\text { cost }\end{array}$ & 500000000 & IDR & - & - & $\begin{array}{l}\text { Occurs at the } \\
\text { beginning } \\
\text { and then } \\
\text { every ten } \\
\text { years }\end{array}$ & [109] \\
\hline $\begin{array}{c}\text { Other initial } \\
\text { investment } \\
\text { cost }\end{array}$ & 376702000 & IDR & - & - & $\begin{array}{l}\text { Occurs only } \\
\text { once in the } \\
\text { beginning }\end{array}$ & [109] \\
\hline $\begin{array}{c}\text { Other } \\
\text { reinvestmen } \\
t \text { cost }\end{array}$ & 28892000 & IDR & - & - & $\begin{array}{l}\text { Occurs every } \\
\text { five years }\end{array}$ & [109] \\
\hline $\begin{array}{c}\text { Price of } \\
\text { commission } \\
\text { ed } \\
\text { distillation }\end{array}$ & 500000 & $\begin{array}{c}\text { IDR } \\
\text { distillation } \\
-1\end{array}$ & - & - & - & $\begin{array}{c}\text { Field } \\
\text { interview }\end{array}$ \\
\hline $\begin{array}{l}\text { Profit from } \\
\text { yardlong } \\
\text { beans }\end{array}$ & 2550000 & IDR $y^{-1}$ & - & - & - & {$[110]$} \\
\hline $\begin{array}{c}\text { Harvests of } \\
\text { yardlong } \\
\text { beans }\end{array}$ & 3 & $\begin{array}{l}\text { harvests } \\
\mathrm{yr}^{-1}\end{array}$ & - & - & - & {$[110]$} \\
\hline Oil price & 560000 & IDR $\mathrm{kg}^{-1}$ & $\begin{array}{c}48600 \\
0 \\
\end{array}$ & $\begin{array}{c}76400 \\
0 \\
\end{array}$ & & $\begin{array}{c}\text { Field } \\
\text { interview }\end{array}$ \\
\hline $\begin{array}{l}\text { Discount } \\
\text { rate }\end{array}$ & 0.11 & - & - & - & - & $\begin{array}{c}\text { Field } \\
\text { interview }\end{array}$ \\
\hline Tax rate & 0.25 & - & - & - & - & [109] \\
\hline $\begin{array}{c}\mathrm{PV} \\
\text { installation } \\
\text { cost } \\
\end{array}$ & 36230 & $\mathrm{IDR}_{\mathrm{p}}{ }^{-1}$ & - & - & - & {$[80]$} \\
\hline $\begin{array}{c}\text { Annual } \\
\text { operation } \\
\text { expenditure } \\
\text { of PV }\end{array}$ & 181 & $\begin{array}{l}\text { IDR W }_{p^{-1}} \\
\text { year }^{-1}\end{array}$ & - & - & - & {$[80]$} \\
\hline $\begin{array}{l}\text { Wholesale } \\
\text { of } \\
\text { electricity }\end{array}$ & 2743 & $\underset{1}{\text { IDR }_{1} \mathrm{kWh}^{-}}$ & 2000 & 2500 & $\begin{array}{l}\text { Wholesale } \\
\text { price } \\
\text { assumed to } \\
\text { be the same } \\
\text { as the feed-in } \\
\text { tariff. Range } \\
\text { user-defined. }\end{array}$ & $\begin{array}{c}\text { MEMR } \\
\text { Regulatio } \\
\text { n No. } \\
\text { 19/2016 }\end{array}$ \\
\hline
\end{tabular}




\subsubsection{Uses for The Energy Output from The Solar PV}

The energy inputs/outputs of the standalone solar PV were compared to an annual electricity demand of a theoretical rural village in Indonesia. The annual electricity demand of the theoretical village was calculated from the grid load schedule of a theoretical village used in the technoeconomic analysis by Blum et al [12]. The village consisted of 350 households with identical demand profile, commerce, and social infrastructure. The theoretical daily electrical demand profile from which the annual total electricity demand was calculated is described in detail in Blum et al [12].

\subsection{Results}

Both annual energy requirement per unit hectare and annual GHG emissions per unit hectare of patchouli cultivation and distillation land use showed more than $10 \%$ deviation from the base case outputs with $50 \%$ decrease or $50 \%$ increase to the following variables: the number of plants per hectare, fresh yield per plant per harvest, the ratio of unit mass of dry yield to fresh yield, the capacity of the distillation unit, and the firewood required per distillation.

The energy requirement was also sensitive to the age of maturity of patchouli plants, the effective heat of combustion of firewood, and the GHG emissions were also sensitive to the size of the building, maximum number of distillations per year, and emissions per unit area of the building. However, both energy requirement and GHG emissions of the patchouli land use were less sensitive to the changes in the consumption of agrochemicals.

The Monte Carlo simulations yielded a mean annual energy input of $345 \mathrm{GJ} \mathrm{ha}^{-1}$ with a standard deviation of $12.8 \mathrm{GJ} \mathrm{ha}^{-1}$ for standalone solar PV land use whereas a mean annual energy input of $102 \mathrm{GJ} \mathrm{ha}^{-1}$ with a standard deviation of $6.10 \mathrm{GJ} \mathrm{ha}^{-1}$ for a patchouli 
cultivation and distillation (Fig. 4-2). The output from solar PV far exceeds the energy requirement for patchouli cultivation and distillation.

Whereas the energy input of standalone solar PV land use was more than three times that of patchouli and-use, the mean annual GHG emissions from a hectare of standalone PV (25.7 Mg) and from patchouli cultivation and distillation $(23.7 \mathrm{Mg})$ were similar (Fig. 4-3). In addition, standalone PV produces $2.06 * 10^{3}$ GJ (Fig. 4-2), which translated to 7.00 * $10^{2} \mathrm{Mg}$ offset against the GHG emissions from diesel electricity generation, and $4.21 *$ $10^{2} \mathrm{Mg}$ offset against the grid emissions (Fig. 4-3).

The Monte Carlo simulation of NPV from land uses yielded the mean and standard deviation of patchouli land-use were $2.25 * 10^{9}$ IDR and $7.26 * 10^{8}$ IDR, whereas those of standalone PV land-use were $-4.32 * 10^{10}$ IDR and $1.18 * 10^{10}$ IDR (Fig. 4-4). The mean NPV and the standard deviation of the co-located land-use with low-density PV installation and full patchouli yield was $-1.27 * 10^{10}$ IDR. The Monte Carlo simulation shows that the NPV of both land uses involving PV (standalone solar and co-located) are less constrained than that of patchouli land use. The patchouli land use is far more profitable than both the standalone PV land use and the co-located crop-PV land use. This result is comparable to that of existing studies on PV-Crop co-location [14].

Assuming no loss between photovoltaic electricity production and end-use, a hectare of standalone PV land-use was able to generate enough electricity (2055 GJ $\mathrm{yr}^{-1}$ ) to satisfy the annual energy demand ( $832 \mathrm{GJ} \mathrm{yr}^{-1}$ ) of a village of 350 households and its commercial and public energy use. Approximately two-thirds of the produced energy (1223

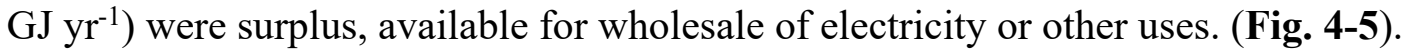


Table 4-5. Results of the sensitivity analysis (energy input)

\begin{tabular}{|c|c|c|c|c|c|}
\hline \multirow[b]{2}{*}{$\begin{array}{l}\text { Model } \\
\text { Inputs }\end{array}$} & \multicolumn{3}{|c|}{ Energy input (GJ ha-1) } & \multicolumn{2}{|c|}{ Output differential (\%) } \\
\hline & $\begin{array}{l}\text { Low }(50 \% \\
\text { of Base } \\
\text { input })\end{array}$ & $\begin{array}{l}\text { Moderate } \\
\text { (100\% of } \\
\text { the base } \\
\text { input) }\end{array}$ & $\begin{array}{l}\text { High } \\
\text { (150\% of } \\
\text { the base } \\
\text { input) }\end{array}$ & $\begin{array}{l}\text { Low- } \\
\text { Moderate }\end{array}$ & $\begin{array}{l}\text { High- } \\
\text { Moderate }\end{array}$ \\
\hline $\begin{array}{l}\text { Months to } \\
\text { maturity }\end{array}$ & 122.0 & 102.2 & 82.5 & 19.3 & -19.3 \\
\hline $\begin{array}{l}\text { Fresh yield } \\
\left(\mathrm{kg} \mathrm{plant}^{-1}\right. \\
\left.\text { harvest }^{-1}\right)\end{array}$ & 57.9 & 102.2 & 146.5 & -43.3 & 43.3 \\
\hline $\begin{array}{l}\text { Fresh-to-dry } \\
\text { mass ratio }\end{array}$ & 57.9 & 102.2 & 146.5 & -43.3 & 43.3 \\
\hline $\begin{array}{l}\text { Distillation } \\
\text { capacity }\end{array}$ & 190.8 & 102.2 & 72.7 & 86.6 & -28.9 \\
\hline $\begin{array}{l}\text { Firewood } \\
\text { consumption } \\
\text { per } \\
\text { distillation }\end{array}$ & 59.2 & 102.2 & 145.3 & -42.1 & 42.1 \\
\hline $\begin{array}{l}\text { Firewood } \\
\text { energy } \\
\text { content }\end{array}$ & 59.2 & 102.2 & 145.3 & -42.1 & 42.1 \\
\hline
\end{tabular}


Table 4-6. Results of the sensitivity analysis (GHG emissions)

\begin{tabular}{|c|c|c|c|c|c|}
\hline \multirow[b]{2}{*}{ Model Inputs } & \multicolumn{3}{|c|}{ GHG emissions (Mg ha $\left.{ }^{-1}\right)$} & \multicolumn{2}{|c|}{$\begin{array}{c}\text { Output differential } \\
(\%)\end{array}$} \\
\hline & $\begin{array}{l}\text { Low } \\
(50 \% \text { of } \\
\text { Base } \\
\text { input })\end{array}$ & $\begin{array}{l}\text { Moderate } \\
\text { (100\% of } \\
\text { the base } \\
\text { input) }\end{array}$ & $\begin{array}{l}\text { High } \\
(150 \% \text { of } \\
\text { the base } \\
\text { input) }\end{array}$ & $\begin{array}{l}\text { Low- } \\
\text { Moderate }\end{array}$ & $\begin{array}{l}\text { High- } \\
\text { Moderate }\end{array}$ \\
\hline $\begin{array}{l}\text { Plants per } \\
\text { hectare }\end{array}$ & 13.1 & 24.6 & 36.0 & -46.5 & 46.5 \\
\hline $\begin{array}{l}\text { Months to } \\
\text { maturity }\end{array}$ & 29.4 & 24.6 & 19.7 & 19.6 & -19.6 \\
\hline $\begin{array}{l}\text { Fresh yield }(\mathrm{kg} \\
\left.\text { plant }^{-1} \text { harvest }^{-1}\right)\end{array}$ & 13.3 & 24.6 & 35.8 & -45.9 & 45.9 \\
\hline $\begin{array}{l}\text { Fresh-to-dry } \\
\text { mass ratio }\end{array}$ & 13.3 & 24.6 & 35.8 & -45.9 & 45.9 \\
\hline Building area & 12.4 & 24.6 & 44.8 & -49.4 & 82.4 \\
\hline $\begin{array}{l}\text { Maximum } \\
\text { number of } \\
\text { distillations per } \\
\text { year }\end{array}$ & 41.1 & 24.6 & 19.0 & 67.4 & -22.5 \\
\hline $\begin{array}{l}\text { Distillation } \\
\text { capacity }\end{array}$ & 47.1 & 24.6 & 17.0 & 91.7 & -30.6 \\
\hline $\begin{array}{l}\text { Firewood } \\
\text { consumption per } \\
\text { distillation }\end{array}$ & 21.6 & 24.6 & 27.5 & -12.2 & 12.2 \\
\hline $\begin{array}{l}\text { Embodied } \\
\text { emission per } \\
\text { building area }\end{array}$ & 16.5 & 24.6 & 32.6 & -32.9 & 32.9 \\
\hline $\begin{array}{l}\text { GHG emission } \\
\text { per mass of } \\
\text { firewood burnt }\end{array}$ & 21.6 & 24.6 & 27.5 & -12.2 & 12.2 \\
\hline
\end{tabular}




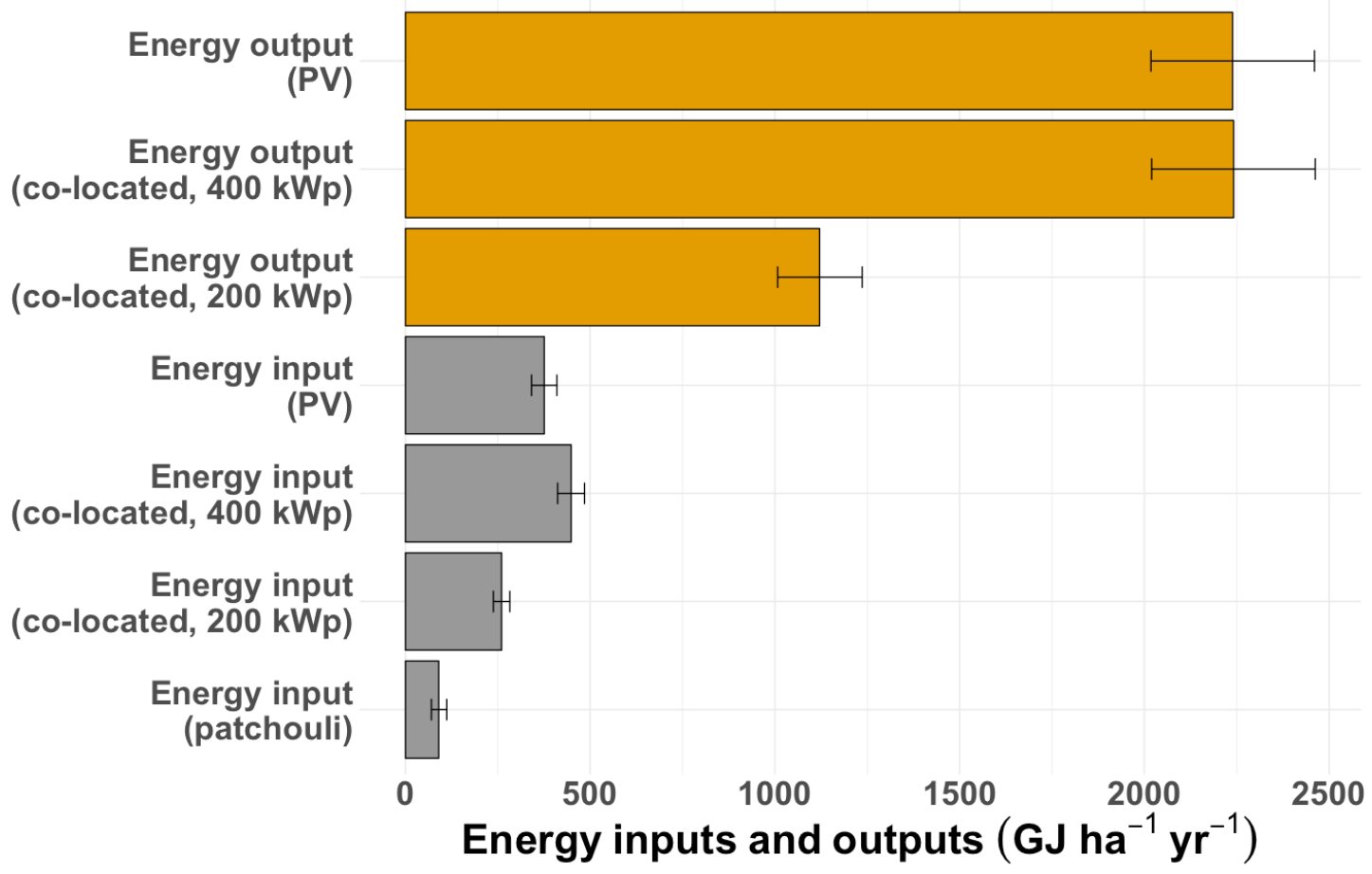

Figure 4-2. Energy inputs and outputs from standalone solar PV land use, co-located land use with $400 \mathrm{kWp} \mathrm{ha}^{-1}$ module density, co-located land use with $200 \mathrm{kWp} \mathrm{ha}^{-1}$ module density; and energy input for patchouli cultivation and distillation. The yellow bars represent the energy produced by the PV component of the respective land uses (in parentheses), and the gray bars represent the energy requirement for each land uses. The error bars represent the $10^{\text {th }}$ and the $90^{\text {th }}$ percentile of the frequency distribution. 


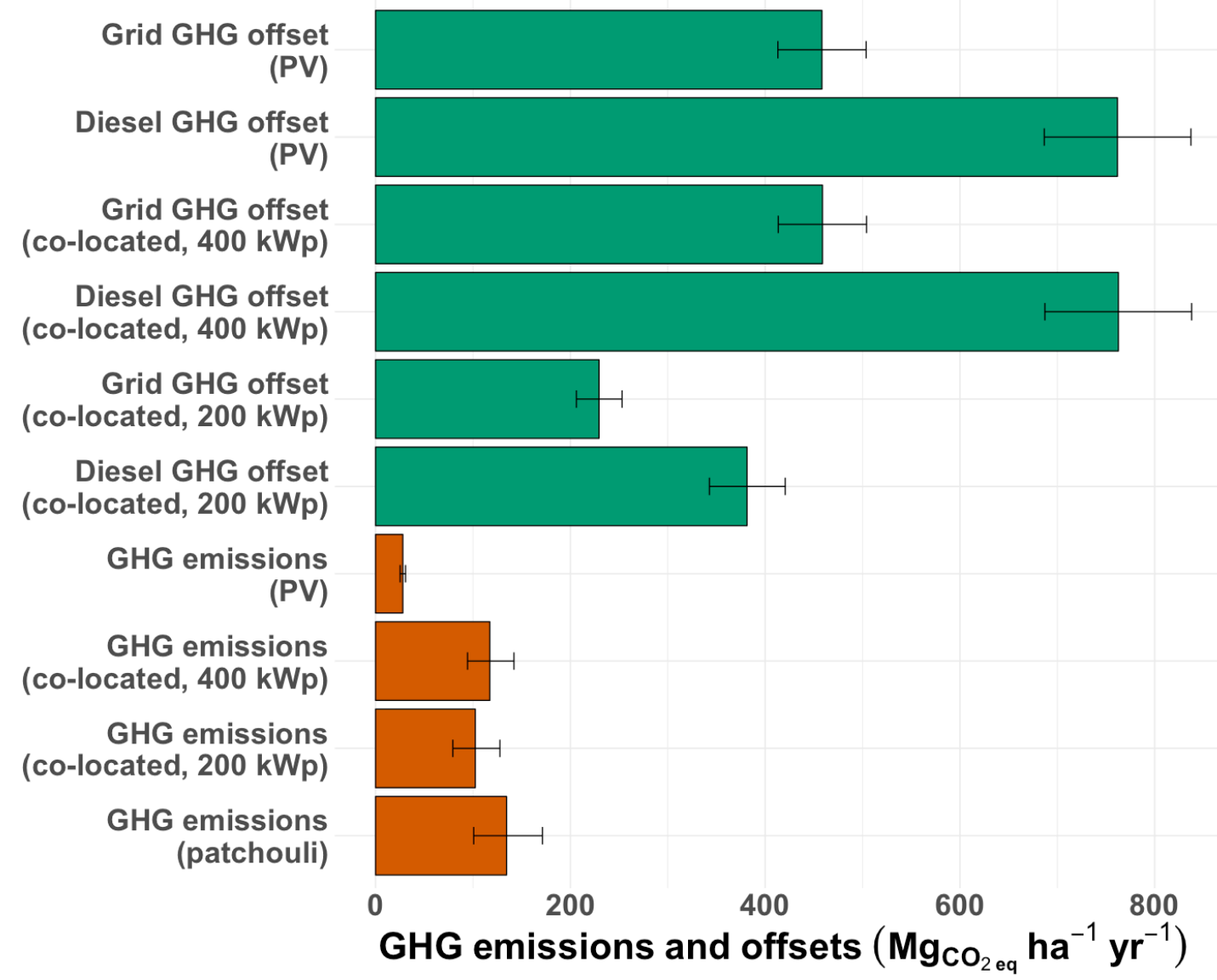

Figure 4-3. GHG emissions and offsets from standalone solar PV land use, co-located land use with $400 \mathrm{kWp} \mathrm{ha}^{-1}$ module density, co-located land use with $200 \mathrm{kWp} \mathrm{ha}^{-1}$ module density; and GHG emissions for patchouli cultivation and distillation. The green bars represent the GHG gas offsets against diesel or grid by the PV component of the respective land uses (in parentheses), and the orange bars represent the GHG emissions from the respective land uses. The error bars represent the $10^{\text {th }}$ and the $90^{\text {th }}$ percentile of the frequency distribution. 


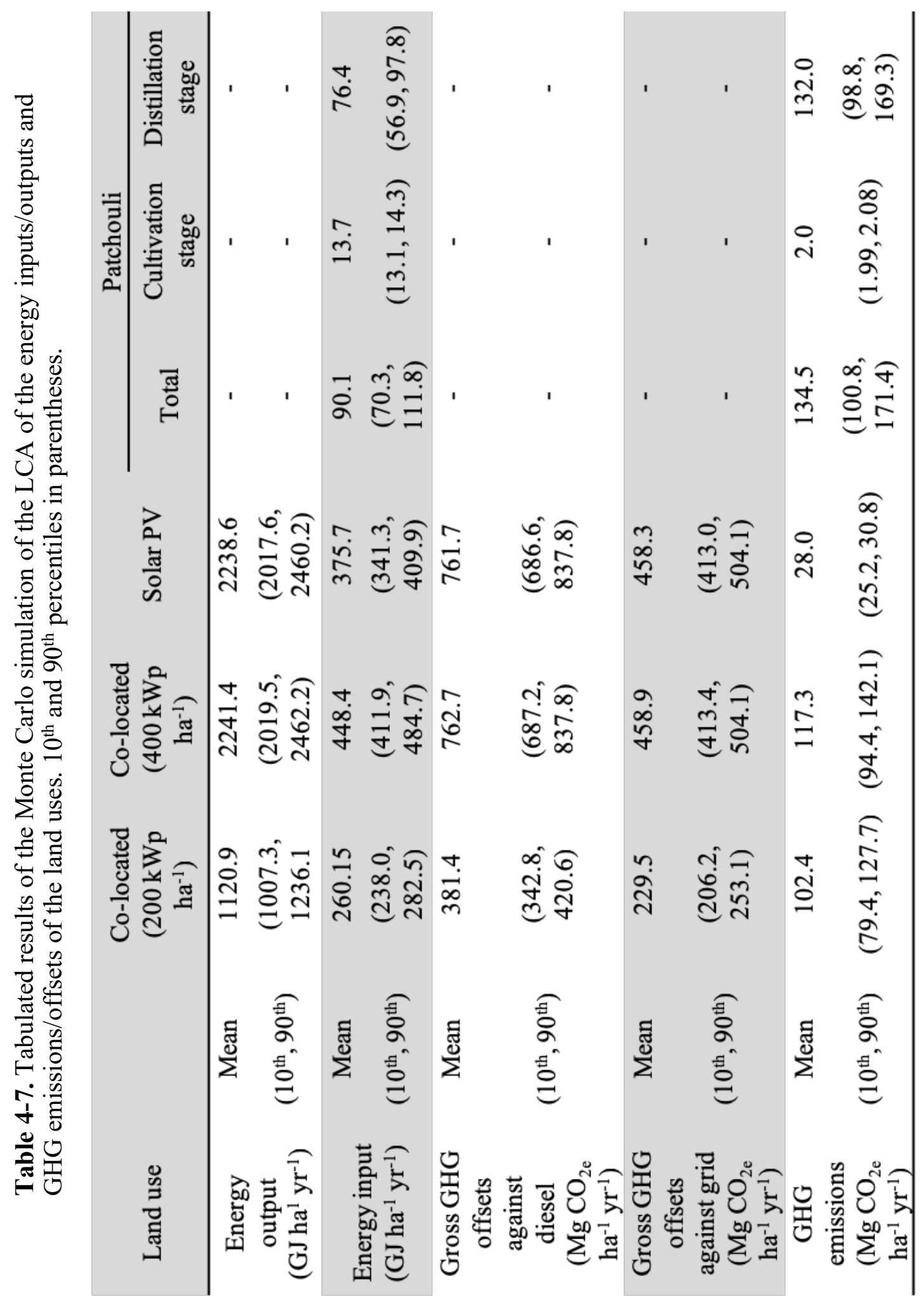




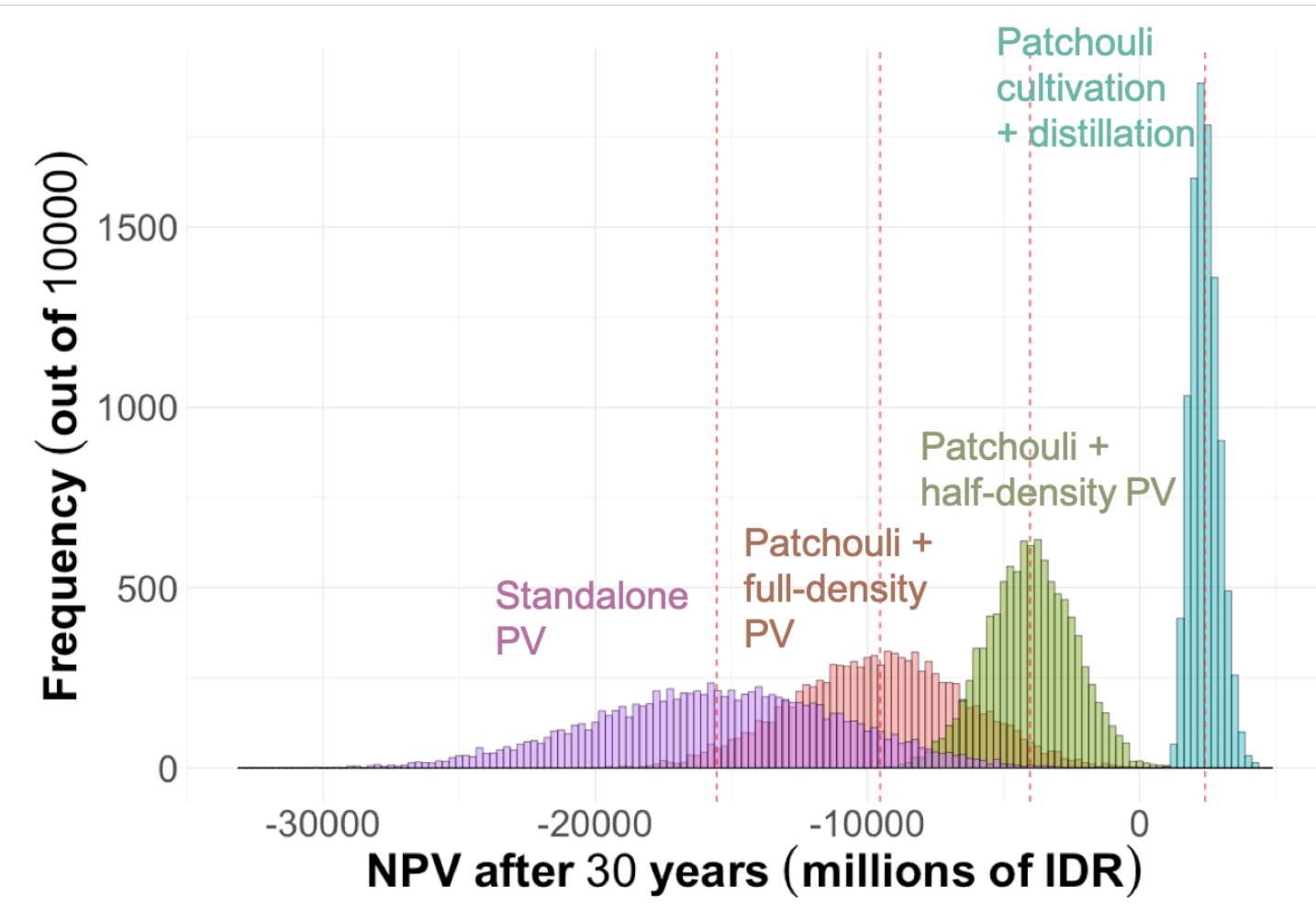

Figure 4-4. Net present value (NPV) frequency distributions from Monte Carlo analysis $(\mathrm{n}=10,000)$ where the $\mathrm{x}$-axis represents NPV in Indonesian Rupiah (IDR). The red, dotted line at the center of each curve represents the mean NPV. 


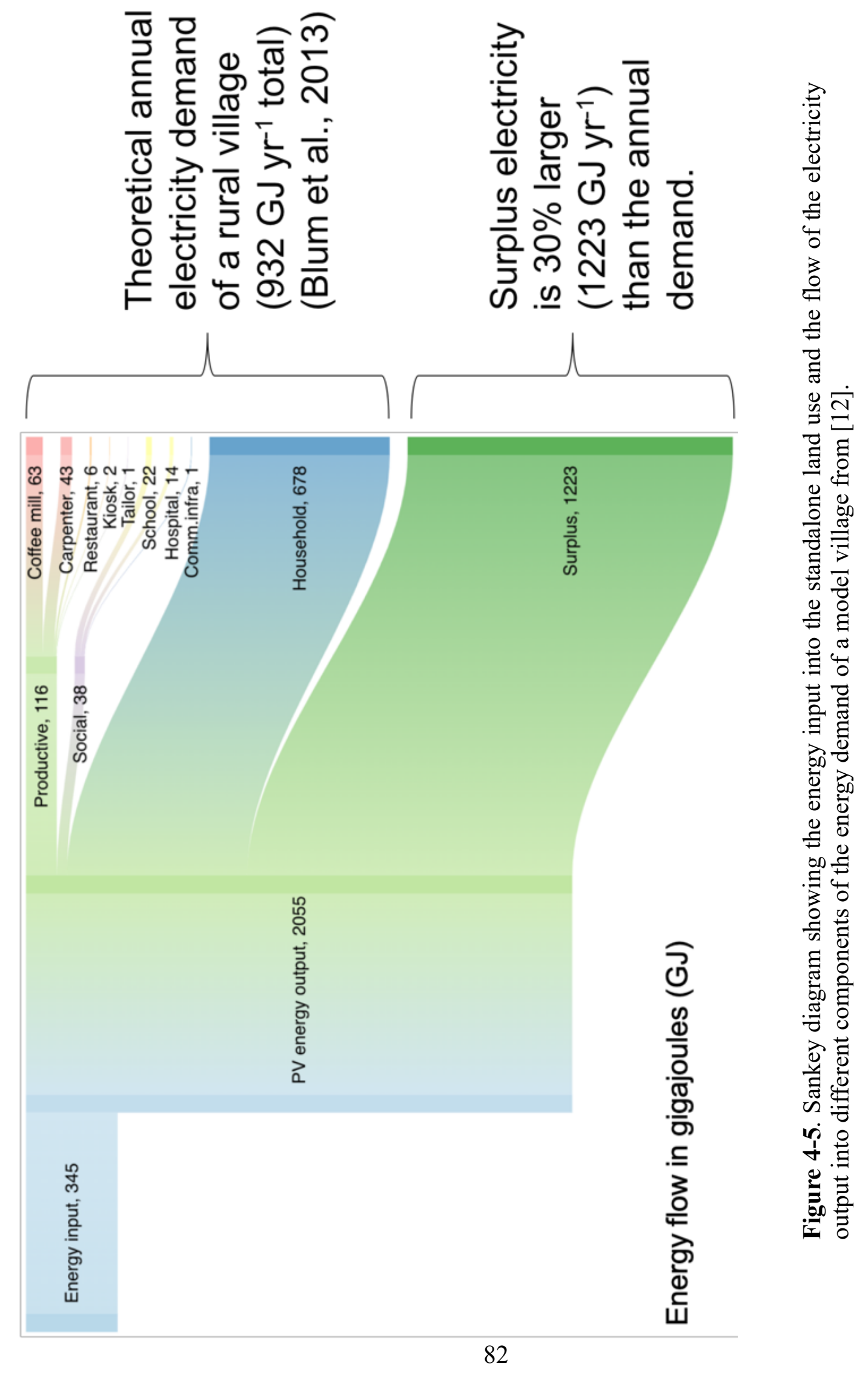




\subsection{Discussion}

Both energy requirement and GHG emissions of patchouli cultivation and distillation were sensitive to the variables that controlled the number of distillations per year, such as the number of plants per hectare, fresh yield per plant per harvest, and the ratio of unit mass of dry yield to fresh yield. The energy requirement and the GHG emissions increase and decrease with the dry yield per hectare because the number of distillations, which is accompanied by a significant amount of firewood consumption, is dependent upon the dry yield available for distilling.

Supposing that the heat required for distilling essential oil from a unit mass of the dry yield, the change in effective heat of combustion of firewood should have resulted in a change in firewood consumption per distillation. However, it is unclear how much heat is actually recovered from the combustion of firewood in practice due to the lack of data on variables that the combustion depends on, such as the degree to which firewood is dried before being ignited. While the model calculates the energy requirement and the GHG emission of the distillation process based on the assumption that firewood is completely combusted, complete combustion of firewood is unlikely, and therefore the model likely overestimates the energy requirement and the GHG emission of the distillation process.

For the LCA of patchouli distillation, firewood consumption was not modeled as a function of heat required for distillation, but as a quantity of firewood required per distillation. Therefore, the GHG emissions were not sensitive to the effective heat of combustion. The sensitivity of GHG emissions and energy requirement per hectare highlights the importance of finding a heat source alternative to wood combustion.

The ratio of gross annual per-hectare energy output to input of the standalone photovoltaic land-use (376.1 and 2241.7 GJ ha-1 $\mathrm{yr}^{-1}$, Table 4-6) were comparable to those 
of photovoltaic plants in other LCA studies $[8,14,111]$. One difference is that the output is lower in tropical Indonesia than the drylands in those studies since it receives less annual irradiation $[8,14]$. The similarity was also apparent in the LCA of the GHG emissions from the standalone PV land use, as the GHG emission was $28.0 \mathrm{~kg}_{\mathrm{CO} 2 \mathrm{e}} \mathrm{ha}^{-1} \mathrm{yr}^{-1}(25.9-30.1)$. However, the offset of GHG emissions against diesel electricity generation of this study was almost twice that of other studies $[8,14]$.

The large energy input and GHG emission of the patchouli cultivation were attributed to two factors: one, heightened usage of agrochemicals due to the high nutrient demand of patchouli cultivation, and two, usage of firewood during the steam distillation of patchouli. The energy input and the GHG emission could be mitigated in the cultivation stage by reducing the application of agrochemicals and increasing the use of organic fertilizer, and in the distillation stage by using a solar water boiler or other low-emission technology sufficient of generating enough heat.

Standalone PV land use was determined to be highly unprofitable in all cases, while patchouli cultivation and distillation was determined to be mostly profitable (Fig. 4-4). The large negative value of NPV of standalone PV land use is primarily attributed to the fact that a large portion of the cost of standalone PV land use is from large investment capital required for installation [14]. Furthermore, the economic model assumes that no subsidy exists for solar besides the FiT that varies from 2000-2500 IDR (Table 4-5). The Ministry of Energy and Mineral Resources regulation 50/2017 makes available few different types of subsidy for renewable energy generation, such as Build, Own, Operate, and Transfer projects or an FiT as $85 \%$ of the local cost of generation for areas where the local cost of generation is higher than the national average, or as a business-to- business tariff pending governmental approval for areas with cost of generation lower than that of the national 
average $[81,112]$. This policy attempts to promote renewable energy development in rural areas with low electrification rates [81]. However, the average and regional cost of generation is brought down by cheap, subsidized coal generation which has resulted in a low cap on FiT and wholesale price of electricity [81]. In addition to the ineffective subsidy to renewable energy, another factor that causes the highly negative NPV of the standalone solar land uses is that the LCA model does not consider the secondary benefits of the electrification, such as the revenue generated by enterprises enabled by electrification (Fig. 4-5) or the avoidance of potential health costs of the local pollution due to coal-fired or diesel power plants (e.g. hospital or municipal groundwater pumping) [113,114].

The co-located land use with full-density PV (400 kWp ha-1) and patchouli shows a visible shift in the profitable direction, as the economic variables and outcomes were a simple addition of the two separate land uses. The shift of the curve to the positive side is due to the income stream from the patchouli component of the co-location. However, the land use is still highly negative.

The fact that a hectare of full-density PV array could produce more than twice the annual demand of the model village of 350 households (Fig. 4-5) means that the same village can be electrified with an array less than half the size $\left(\sim 200 \mathrm{~kW}_{\mathrm{p}} \mathrm{ha}^{-1}\right)$. Taking into account this fact, the NPV of the co-located land use only had 50\% of the module density of that of the standalone PV land use, and the shift of the NPV towards the positive in the co-located land use can be attributed to not only the profitability of patchouli, but also to the decrease in the investment cost of the PV component after reducing the module density to the half of the full module density. It is also worth noting that agricultural enterprises yield periodic revenue upon sale of the harvests, whereas electrical generation provides much shorter-term revenue generation. Therefore, the combination of solar PV electricity 
generation with agricultural enterprises may lead to a more stable local economy and less impact from the income variation owing to lean months or poor yields. Furthermore, using the excess energy to locally refine agricultural products may reduce the transportation cost from the site of raw material production to the processing facility and yield higher returns per hectare, provided that the processed agricultural product is more profitable than the raw agricultural material.

The high investment cost of solar and the fact that a hectare of standalone PV land use could satisfy the typical village's electricity requirement three times over make a strong case for a vegetation-centric approach of PV-patchouli co-location rather than the energycentric approach. Using the vegetation-centric approach, the PV array can be spread over several hectares of adjacent fields of patchouli. Satisfying the energy demand of the same model village would require one half of the modules required for a full-density PV land use, and the reduced number of modules could then be spread over three hectares of adjacent patchouli cultivation for the module density per area one-ninth of the full module density, which may result in negligible loss in patchouli yield. It had been estimated that cultivation of crop with full-density PV operation would only result in $17 \%$ loss in yield and $20 \%$ loss in dry matter [15]. However, patchouli adapts to shaded conditions by increasing leaf area and pigment, which ensures that patchouli can be grown under a canopy without affecting oil yield [88]. Patchouli's adaptive features and the extremely low PV module density may eliminate yield loss altogether, though a more detailed simulation of distribution of solar irradiation under low-density panel and verification of the relative yield with a physical model involving patchouli cultivation would be required.

Taking the NPV of the standalone PV land use (Fig. 4-2) and the LCOE of PV (Fig. 4-6) at their face value, other renewable sources or even conventional sources may be 
preferred for rural electrification over a widespread deployment of distributed PV arrays. However, most of these alternatives, barring diesel and land-based wind power, have higher capital expenditure, and the high upfront cost may be more difficult for rural communities to manage than a lower upfront cost of PVs.

In this context, Indonesia's goal to increase its installed PV capacity is prudent. Despite the self-imposed goal, the Indonesian government has not been providing any effective political support for the solar, as is evident in its coal subsidy that has been pitting coal power against the PV. Should the MEMR decide to subsidize solar in the future in a manner that is not dependent on the subsidized cost of coal power, the cost of PV generation could decrease, resulting in the positive shift of the NPVs of land uses with PV components.

Another barrier to fully realizing the technical potential of solar is the land occupation. Just as Indonesia needs to increase its generation capacity and electrification rates without incurring further GHG emissions, it is also important that they do so with minimal land-transformation: Indonesia currently has the highest deforestation rates in the world, which has resulted in reduction in primary production and carbon sequestration $[117,118]$. With their high dependence on coal power whose fuel sources often overlap with forested areas, and burgeoning cultivation of high-value crops (e.g. oil palm, patchouli, biofuel feedstocks), this trend is unlikely to change its course in the near future $[82,119$ 121]. A more recent study in the energy transition scenario projects that as much as 750 TWh of Indonesia's electricity may come from solar PV by 2050 [122]. At mean power density of $400 \mathrm{~kW} \mathrm{ha}^{-1}$ [14] and average annual electricity output of $1376 \mathrm{kWh} / \mathrm{W}_{\mathrm{p}}$ [22], 

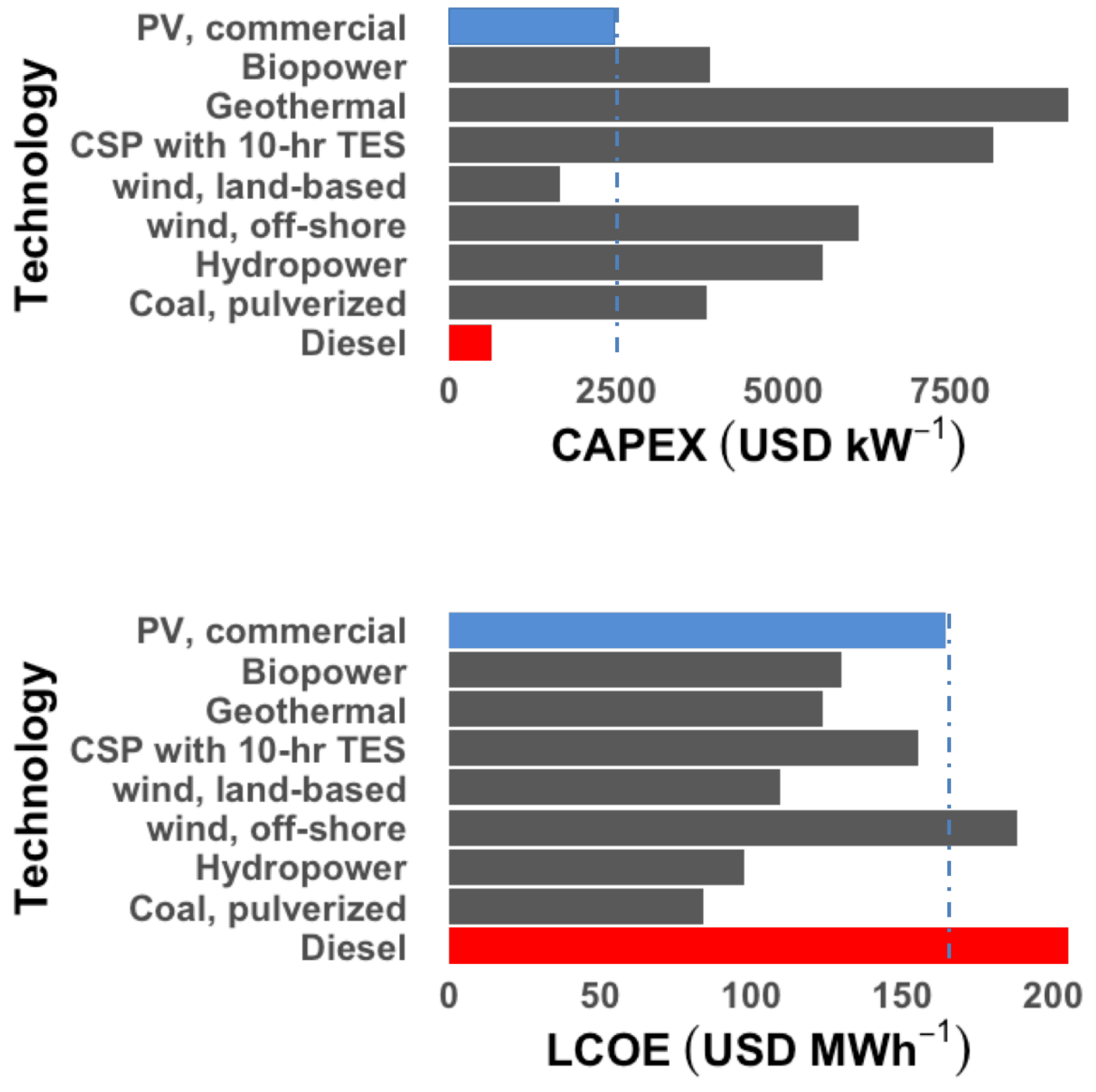

Figure 4-6. Comparison of capital expenditure (CAPEX) and levelized cost of energy (LCOE) among renewable sources in the US. Data from [115]. Diesel costs in Indonesia from [116]. Comparison of capital expenditure (CAPEX) and levelized cost of energy (LCOE) among renewable sources in the US. Data from [115]. Diesel costs in Indonesia from [116]. 
PV generation of such scale would require approximately 1.4 million hectares $(0.5 \%$ of Indonesia's total landmass, $2 \%$ of Indonesia's total agricultural land use, and $1 \%$ of Indonesia's forest cover). While this land footprint is small compared to the total land area of Indonesia, it may still contribute significantly to the overall impact of deforestation for a few reasons: 1) many of the environmental responses to the deforestation are non-linearly related to the extent of deforestation, and 2) separating the nonlinear responses from the linear responses is difficult [123]. 3) Furthermore, the indirect and regional effects due to the habitat fragmentation caused by conventional solar facilities are also difficult to quantify and mitigate, as repatriation and translocation programs have low success rates $(<20 \%)$ [7]. The PV-patchouli co-location land use is designed to address this conundrum; based on the breakdown of the annual generation per hectare of standalone PV land use, only one half the number of modules (approximately 1500 modules ha-1 or $180 \mathrm{~kW} \mathrm{ha} \mathrm{h}^{-1}$ ) would be required to satisfy the energy demand of a village (Fig. 4-4). Yield loss in a halfdensity agrivoltaic system is estimated to be $17 \%$ of the crop yield in the full sun. At this loss rate, reaching $750 \mathrm{TWh}$ of PV electricity by implementation of the co-location design in pre-existing farmlands would require 2.7 million hectares of crop-PV co-location, which would crop yield loss equivalent to 0.459 million hectares of loss in food production and no deforestation, compared to 1.4 million hectares of loss in farmlands and/or deforestation that would be caused by the conventional PV land use. To further reduce the crop yield loss caused by the shading from the solar panels, the solar PV density could be further reduced by spreading the PV array over adjacent farm lands. Doing so may also divide the burden of capital expenditure, which may be difficult for any single landowner to shoulder, over several landowners. 
However, the implied avoided land use created by the co-location design uses a limited range of parameters and just one crop. While patchouli was chosen as the ideal crop to demonstrate the feasibility of the co-location scheme, Indonesia has wide climactic regimes, and patchouli-PV co-location may not be feasible in climates and soil conditions unsuitable for patchouli growth. Conversely, other plants that satisfied the following logistical and physiological requirements for a given climate would be just as worth investigating as patchouli:

1) The crop is already cultivated in the area.

2) Facilities for processing the crop and marketing channels are already in place.

3) The crop needs to be shade-tolerant in order to thrive under the partial shading created by the solar PV.

4) The crop needs to have a short stature so as not to shade the solar PV.

5) The crop must have a relatively long commercial lifespan so that the location of the co-located system is not frequently disturbed for re-planting the crop.

Lastly, It is entirely possible that the yield loss will be even smaller than $17 \%$ at half-density, as pilot studies on co-location of different crops in climates other than the tropics have reported less than $17 \%$ crop yield loss and even yield increases $[70,84]$. Confirmation of the findings of this study is contingent upon a pilot study.

\subsection{Conclusion}

Indonesia faces increasing competition between food and energy production caused by its fast-growing population and a desire to support economic growth. However, the country's susceptibility to the impacts of climate change, ongoing rapid deforestation, and the geographic barrier stemming from the archipelagic geography of Indonesia require that 
the drastic increase in energy supply must be achieved without increasing GHG emissions and while minimizing land use. As a renewable energy, solar photovoltaics (PV) is a low emission energy source that is less geographically constrained than other renewable energy technologies. These characteristics make PV an important candidate for resolving Indonesia's energy woes. However, dedicated PV energy production usually entails a large land footprint, which is a concern because of the competition for land between the food and the energy sectors. This issue is mitigated with a vegetation-centered crop-PV colocation design: while implementing standalone, ground-mounted solar to meet the projected solar electricity production of $750 \mathrm{TWh} \mathrm{yr}^{-1}$ is estimated to result in loss of 1.4 million hectares of forest or arable land, producing the same amount of electricity through implementing the vegetation-centered crop-PV in pre-existing agricultural will only result in no deforestation and total yield loss equivalent to only 0.46 million hectares of arable land, which is less than a third of the loss estimated by the ground-mounted solar PV scenario.

To test the environmental and economic feasibility of the co-location design, life cycle analysis of energy inputs/outputs, GHG emissions/offsets, and NPV distribution were performed for three different land uses - standalone PV land use, patchouli land use, and co-located patchouli-PV land use. The LCA of standalone PV land use indicated enough annual energy production to satisfy the energy demand of a theoretical village three times over, which would in turn result in a significant offset of GHG emissions against either diesel electricity generation or grid supply of the same scale. However, the highly negative NPV of standalone PV land use (around - 20 billion IDR and -1.4 million USD) also revealed that PV was very cost-prohibitive, and that the FiT set by the Indonesian government did little to offset the cost of solar PV. Given that the PV generation was so 
expensive, the reduced panel density would not only decrease the initial capital but also minimize the loss of crop yield per unit area while generating enough electricity to support a sizeable rural community.

In order for PV land uses to be profitable in the near future, the Indonesian government should either implement an FiT that is more reflective of the generation cost of PV, or reduce the existing subsidies for coal and other fossil fuel in order to ensure fair competition for renewable energies. In the long run, however, the downward trend in the cost of PV will likely shift the NPV in the positive direction.

In light of these findings, it was determined that vegetation-centered crop-PV colocation would be the best PV configuration for electrifying remote rural communities and minimizing the impact of PVs land and financial footprint. 


\section{CHAPTER 5}

\section{CONCLUSION}

Our findings directly address the key questions regarding the physico-chemical impacts of the photovoltaic (PV) array to the soil beneath in the context of cropphotovoltaic co-location between vegetation and the environmental performance of the colocation land use in the tropics. To determine the impacts of the photovoltaic array on the underlying soil, we analyzed the hydrology, nutrient levels, and particle size distributions of the soil under the PV array, the findings from which was used determine how the environmental alterations by the PV could be utilized to optimize the co-location design. The soil under the panels seemed to have heightened volumetric soil moisture content (VSM) as a result of the concentration of run off from the module tilted at an angle. Additionally, the soil carbon and nitrogen contents were lower in the soil underlying the solar array than they were in an adjacent undisturbed plot where neither vegetation nor topsoil had been disturbed for construction despite the success of the revegetation effort that had taken place seven years prior. Therefore, it was determined that additional implementation of vegetation-PV co-location should be implemented without disturbing the pre-existing vegetation or soil.

As for the performance of the co-location design in Indonesia, the emissions and net present values of four land uses (patchouli, standalone PV, full PV density co-location, and half PV density co-location) were modeled using a life cycle approach. Patchouli would have a bigger GHG and energy footprint due to its distillation process that required wood burning, but standalone PV would more than be able to compensate for patchouli's GHG emission by creating GHG offset against diesel generation or grid utilization of the same amount of energy generated by the PV. However, the NPV indicated that the any PV 
component would result in a significant financial loss, even with wholesale of electricity. The financial disadvantage of the PV in Indonesia was thought to be a result of its government's ineffective subsidization of the solar that in truth pitted the solar against the well-subsidized coal generation. However, the NPV did not take into account indirect benefits of PV electrification such as avoidance of health costs and secondary enterprises. From a land-use efficiency standpoint, crop yield loss from co-location was determined to be small enough even with an overestimation of the yield loss percentage.

In the context of global forest degradation, climate change, and increasing competition between food and energy production, our research suggests that implementation of crop-PV co-location is not only physically viable but also necessary to avoid limiting the PV-occupied land to energy production. 


\section{REFERENCES CITED}

[1] Edenhofer O, Pichs-Madruga R, Sokona Y, Seyboth K, Eickemeier P, Matschoss P, et al. IPCC, 2011: Summary for Policymakers. In: IPCC Special Report on Renewable Energy Sources and Climate Change Mitigation. 2011. doi:10.5860/CHOICE.49-6309.

[2] International Energy Agency. Key world energy statistics. Paris: 2016. doi:10.1787/key_energ_stat-2016-en.

[3] Komiyama H, Yamada K, Inaba A, Kato K. Life cycle analysis of solar cell systems as a means to reduce atomospheric carbon dioxide emissions. Energy Convers Manag 1996;37:1247-52.

[4] Wang J, Feng L, Tang X, Bentley Y, Höök M. The implications of fossil fuel supply constraints on climate change projections: A supply-side analysis. Futures 2015. doi:10.1016/j.futures.2016.04.007.

[5] de Castro C, Mediavilla M, Miguel LJ, Frechoso F. Global solar electric potential: A review of their technical and sustainable limits. Renew Sustain Energy Rev 2013;28:824-35. doi:10.1016/j.rser.2013.08.040.

[6] Deng YY, Haigh M, Pouwels W, Ramaekers L, Brandsma R, Schimschar S, et al. Quantifying a realistic, worldwide wind and solar electricity supply. Glob Environ Chang 2015;31:239-52. doi:10.1016/j.gloenvcha.2015.01.005.

[7] Hernandez RR, Easter SB, Murphy-Mariscal ML, Maestre FT, Tavassoli M, Allen EB, et al. Environmental impacts of utility-scale solar energy. Renew Sustain Energy Rev 2014;29:766-79. doi:10.1016/j.rser.2013.08.041.

[8] Ravi S, Lobell DB, Field CB. Tradeoffs and synergies between biofuel production and large solar infrastructure in deserts. Environ Sci Technol 2014;48:3021-30. doi:10.1021/es404950n.

[9] Population Division. World Population Prospects: the 2017 Revision 2017. https://data.worldbank.org/indicator/SP.POP.TOTL?locations=ID (accessed February 18, 2018).

[10] Kennedy SF. Indonesia's energy transition and its contradictions: Emerging geographies of energy and finance. Energy Res Soc Sci 2018;41:230-7. doi:10.1016/j.erss.2018.04.023.

[11] International Energy Agency. Energy Policies Beyond IEA Countries - Indonesia, 2015. 2015. doi:10.1787/9789264065277-en.

[12] Blum NU, Sryantoro Wakeling R, Schmidt TS. Rural electrification through village grids-Assessing the cost competitiveness of isolated renewable energy technologies in Indonesia. Renew Sustain Energy Rev 2013;22:482-96.

doi:10.1016/j.rser.2013.01.049. 
[13] Firdaus M, Halim A, Harun MH, Azha K, Annuar M, Hadi A, et al. Photovoltaic economic potential for investment portfolio in Southeast Asia. ARPN J Eng Appl Sci 2016;11:11260-5.

[14] Ravi S, Macknick J, Lobell D, Field C, Ganesan K, Jain R, et al. Colocation opportunities for large solar infrastructures and agriculture in drylands. Appl Energy 2016;165:383-92. doi:10.1016/j.apenergy.2015.12.078.

[15] Dupraz C, Marrou H, Talbot G, Dufour L, Nogier A, Ferard Y. Combining solar photovoltaic panels and food crops for optimising land use: Towards new agrivoltaic schemes. Renew Energy 2011;36:2725-32. doi:10.1016/j.renene.2011.03.005.

[16] Macknick J, Beatty B, Hill G. Overview of Opportunities for Co-Location of Solar Energy Technologies and Vegetation Overview of Opportunities for Co-Location of Solar Energy Technologies and Vegetation 2013:24.

[17] OpenEI. Transparent Cost Database. OpenEIOrg 2017. http://en.openei.org/apps/TCDB/transparent_cost_database (accessed January 1, 2017).

[18] Central Intelligence Agency. The World Factbook - Central Intelligence Agency. World Factb 2017. https://www.cia.gov/library/publications/the-worldfactbook/geos/id.html (accessed February 4, 2017).

[19] Pegels K. Solar Energy in Indonesia 2012.

[20] The World Bank Group. Country Historical Climate - Indonesia. World Bank Gr 2017.

http://sdwebx.worldbank.org/climateportal/index.cfm?page=country_historical_cli mate\&ThisCCode=IDN (accessed February 5, 2017).

[21] Tharakan P. Summary of Indonesia's Energy Sector Assessment (ADB Papers on Indonesia No.9). Adb 2015:40.

[22] World Bank Group. Solar Resource and Photovoltaic Potential of Indonesia 2017:86.

[23] International Energy Agency (IEA). Southeast Asia Energy Outlook. World Energy Outlook Spec Rep 2015:131. doi:10.1787/weo-2013-en.

[24] Pikra G, Salim A, Prawara B, Purwanto AJ, Admono T, Eddy Z. Development of Small Scale Concentrated Solar Power Plant Using Organic Rankine Cycle for Isolated Region in Indonesia. Energy Procedia 2013;32:122-8. doi:https://doi.org/10.1016/j.egypro.2013.05.016.

[25] Hernandez RR, Hoffacker MK, Murphy-Mariscal ML, Wu GC, Allen MF. Solar energy development impacts on land cover change and protected areas. Proc Natl Acad Sci U S A 2015;112:13579-84. doi:10.1073/pnas.1517656112. 
[26] Armstrong A, Ostle NJ, Whitaker J. Solar park microclimate and vegetation management effects on grassland carbon cycling. Environ Res Lett 2016;11. doi:10.1088/1748-9326/11/7/074016.

[27] Cook LM, McCuen RH. Hydrologic Response of Solar Farms. J Hydrol Eng 2013;18:536-41. doi:10.1061/(ASCE)HE.1943-5584.0000530.

[28] Armstrong A, Waldron S, Whitaker J, Ostle NJ. Wind farm and solar park effects on plant-soil carbon cycling: Uncertain impacts of changes in ground-level microclimate. Glob Chang Biol 2014;20. doi:10.1111/gcb.12437.

[29] Elamri Y, Cheviron B, Mange A, Dejean C, Liron F, Belaud G. Rain concentration and sheltering effect of solar panels on cultivated plots. Hydrol Earth Syst Sci 2018;22:1285-98. doi:10.5194/hess-22-1285-2018.

[30] Capellán-Pérez I, Arto I, Polanco-Martínez JM, González-Eguino M, Neumann MB. Likelihood of climate change pathways under uncertainty on fossil fuel resource availability. Energy Environ Sci 2016;493:79-83. doi:10.1039/C6EE01008C.

[31] Breyer C, Bogdanov D, Gulagi A, Aghahosseini A, Barbosa LSNS, Koskinen O, et al. On the role of solar photovoltaics in global energy transition scenarios. Prog Photovoltaics Res Appl 2017;25:727-45. doi:10.1002/pip.2885.

[32] U.S. Department of Energy. SunShot Vision Study. 2012. doi:SunShot, Energy Efficiency and Renewable Energy, U.S. Department of Energy. NREL Report No. BK5200-47927; DOE/GO-102012-3037.

[33] Jacobson MZ. Review of solutions to global warming, air pollution, and energy security. Energy Environ Sci 2009;2:148-73. doi:10.1039/B809990C.

[34] Ellabban O, Abu-Rub H, Blaabjerg F. Renewable energy resources: Current status, future prospects and their enabling technology. Renew Sustain Energy Rev 2014;39:748-64. doi:10.1016/j.rser.2014.07.113.

[35] De Marco A, Petrosillo I, Semeraro T, Pasimeni MR, Aretano R, Zurlini G. The contribution of Utility-Scale Solar Energy to the global climate regulation and its effects on local ecosystem services. Glob Ecol Conserv 2014;2:324-37. doi:10.1016/j.gecco.2014.10.010.

[36] Fthenakis V, Kim HC. Land use and electricity generation: A life-cycle analysis. Renew Sustain Energy Rev 2009;13:1465-74. doi:10.1016/j.rser.2008.09.017.

[37] The World Bank. World Bank Open Data n.d. https://data.worldbank.org/indicator/ag.Ind.frst.zs (accessed April 9, 2018).

[38] Henderson-Sellers A, Dickinson RE, Durbidge TB, Kennedy PJ, McGuffie K, Pitman AJ. Tropical deforestation: Modeling local- to regional-scale climate change. J Geophys Res Atmos 1993;98:7289-315. doi:10.1029/92JD02830. 
[39] Pearson TRH, Brown S, Casarim FM. Carbon emissions from tropical forest degradation caused by logging. Environ Res Lett 2014;9:034017.

doi:10.1088/1748-9326/9/3/034017.

[40] Pearson TRH, Brown S, Murray L, Sidman G. Greenhouse gas emissions from tropical forest degradation: an underestimated source. Carbon Balance Manag 2017;12:3. doi:10.1186/s13021-017-0072-2.

[41] Hoffacker MK, Allen MF, Hernandez RR. Land-Sparing Opportunities for Solar Energy Development in Agricultural Landscapes: A Case Study of the Great Central Valley, CA, United States. Environ Sci Technol 2017;51:14472-82. doi:10.1021/acs.est.7b05110.

[42] Goetzberger A, Zastrow A. On the Coexistence of Solar-Energy Conversion and Plant Cultivation. Int J Sol Energy 1982;1:55-69. doi:10.1080/01425918208909875.

[43] Fthenakis V, Kim HC. Life-cycle uses of water in U.S. electricity generation. Renew Sustain Energy Rev 2010;14:2039-48. doi:10.1016/j.rser.2010.03.008.

[44] Sherwani AF, Usmani JA, Varun. Life cycle assessment of solar PV based electricity generation systems: A review. Renew Sustain Energy Rev 2010;14:540-4. doi:10.1016/j.rser.2009.08.003.

[45] Fthenakis VM, Kim HC. Photovoltaics: Life-cycle analyses. Sol Energy 2011;85:1609-28. doi:10.1016/j.solener.2009.10.002.

[46] Turney D, Fthenakis V. Environmental impacts from the installation and operation of large-scale solar power plants. Renew Sustain Energy Rev 2011;15:3261-70. doi:10.1016/j.rser.2011.04.023.

[47] Fthenakis VM, Betita R, Shields M, Vinje R, Blunden J, Shields M, et al. Life cycle analysis of high-performance monocrystalline silicon photovoltaic systems: Energy payback times and net energy production value. 27th Eur Photovolt Sol Energy Conf Exhib 2012:4667-72.

[48] Perez MJR, Fthenakis V. Façade-integrated photovoltaics : A life cycle and performance assessment case study 2012. doi:10.1002/pip.1167.

[49] Leccisi E, Raugei M, Fthenakis V. The energy and environmental performance of ground-mounted photovoltaic systems - A timely update. Energies 2016;9. doi:10.3390/en9080622.

[50] Marrou H, Dufour L, Wery J. How does a shelter of solar panels influence water flows in a soil-crop system? Eur J Agron 2013;50:38-51. doi:10.1016/j.eja.2013.05.004.

[51] Barron-Gafford GA, Minor RL, Allen NA, Cronin AD, Brooks AE, PavaoZuckerman MA. The Photovoltaic Heat Island Effect: Larger solar power plants 
increase local temperatures. Sci Rep 2016;6:35070. doi:10.1038/srep35070.

[52] Beatty B, Macknick J, Mccall J, Braus G, Buckner D, Beatty B, et al. Native Vegetation Performance under a Solar PV Array at the National Wind Technology Center. 2017.

[53] Ravi S, Wang L, Kaseke KF, Buynevich I V., Marais E. Ecohydrological interactions within "fairy circles" in the Namib Desert: Revisiting the selforganization hypothesis. J Geophys Res Biogeosciences 2017;122:405-14. doi:10.1002/2016JG003604.

[54] Zhang R. Determination of Soil Sorptivity and Hydraulic Conductivity from the Disk Infiltrometer. Soil Sci Soc Am J 1997;61:1024. doi:10.2136/sssaj1997.03615995006100040005x.

[55] J.M.A.V. V, A. M, D. F, S. A. Walled off infected in patient with situs totalis inversus. Pancreatology 2017;17:S62-3. doi:10.2136/sssaj1980.03615995004400050002x.

[56] Soil Survey Staff. Natural Resources Conservation Service. Web Soil Surv n.d. https://websoilsurvey.sc.egov.usda.gov/.

[57] Nelson DW, Sommers LE. Total carbon, Organic Carbon, and Organic Matter. In: D.L. Sparks, J.M. Bartels, D.L. Sparks, A.L. Page, P.A. Helmke, R.H. Loeppert, P.N. Soltanpour, M.A, Tabatabai, C.T. Johnston MES, editor. Methods soil Anal. Part 3 Chem. methods. 3rd ed., Madison, WI: Soils Science Society of America, Inc. and American Society of Agronomy, Inc.; 1996, p. 961-1010.

[58] McGeehan SL, Naylor DV. Automated instrumental analysis of carbon and nitrogen in plant and soil samples. Commun Soil Sci Plant Anal 1988;19:493-505. doi:10.1080/00103628809367953.

[59] Mazaheri MR, Mahmoodabadi M. Study on infiltration rate based on primary particle size distribution data in arid and semiarid region soils. Arab J Geosci 2012;5:1039-46. doi:10.1007/s12517-011-0497-y.

[60] J. A. Vomocil and W. J. Flocker. Effect of Soil Compaction on Storage and Movement of Soil Air and Water. Trans ASAE 1961;4:0242-6. doi:10.13031/2013.41066.

[61] Hölzel N, Otte A. Restoration of a species-rich flood meadow by topsoil removal and diaspore transfer with plant material. Appl Veg Sci 2003;6:131-40. doi:10.1111/j.1654-109X.2003.tb00573.x.

[62] Larney FJ, Olson BM, Janzen HH, Lindwall CW. Early impact of topsoil removal and soil amendments on crop productivity. Agron J 2000;92:948-56. doi:10.2134/agronj2000.925948x.

[63] Larney FJ, Li L, Janzen HH, Angers DA, Olson BM. Soil quality attributes, soil 
resilience, and legacy effects following topsoil removal and one-time amendments. Can J Soil Sci 2016;96:177-90. doi:10.1139/cjss-2015-0089.

[64] Walston LJ, Mishra SK, Hartmann HM, Hlohowskyj I, McCall J, Macknick J. Examining the Potential for Agricultural Benefits from Pollinator Habitat at Solar Facilities in the United States. Environ Sci Technol 2018;52:7566-76. doi:10.1021/acs.est.8b00020.

[65] Harbor J. Engineering geomorphology at the cutting edge of land disturbance: Erosion and sediment control on construction sites. Geomorphology 1999;31:24763. doi:10.1016/S0169-555X(99)00107-5.

[66] Croke J, Hairsine P, Fogarty P. Soil recovery from track construction and harvesting changes in surface infiltration, erosion and delivery rates with time. For Ecol Manage 2001;143:3-12. doi:10.1016/S0378-1127(00)00500-4.

[67] Mohammad AG, Adam MA. The impact of vegetative cover type on runoff and soil erosion under different land uses. Catena 2010;81:97-103. doi:10.1016/j.catena.2010.01.008.

[68] Elamri Y, Cheviron B, Lopez JM, Dejean C, Belaud G. Water budget and crop modelling for agrivoltaic systems: Application to irrigated lettuces. Agric Water Manag 2018;208:440-53. doi:10.1016/j.agwat.2018.07.001.

[69] Lin CH, McGraw ML, George MF, Garrett HE. Nutritive quality and morphological development under partial shade of some forage species with agroforestry potential. Agrofor Syst 2001;53:269-81. doi:10.1023/A:1013323409839.

[70] Marrou H, Wery J, Dufour L, Dupraz C. Productivity and radiation use efficiency of lettuces grown in the partial shade of photovoltaic panels. Eur J Agron 2013;44:54-66. doi:10.1016/j.eja.2012.08.003.

[71] Ekouevi K, Portale E, Rysankova D, Jaques I, Bazilian M, Timilsina G, et al. State of Electricity Access Report 2017. Washington, D,C,: World Bank; 2017. doi:10.1596/26646.

[72] Rathi SS, Vermaak C. Rural electrification, gender and the labor market: A crosscountry study of India and South Africa. World Dev 2018;109:346-59. doi:10.1016/j.worlddev.2018.05.016.

[73] Schmidt TS, Blum NU, Sryantoro Wakeling R. Attracting private investments into rural electrification - A case study on renewable energy based village grids in Indonesia. Energy Sustain Dev 2013;17:581-95. doi:10.1016/j.esd.2013.10.001.

[74] Mahapatra S, Dasappa S. Rural electrification: Optimising the choice between decentralised renewable energy sources and grid extension. Energy Sustain Dev 2012;16:146-54. doi:10.1016/j.esd.2012.01.006. 
[75] Narula K, Nagai Y, Pachauri S. The role of Decentralized Distributed Generation in achieving universal rural electrification in South Asia by 2030. Energy Policy 2012;47:345-57. doi:10.1016/j.enpol.2012.04.075.

[76] International Energy Agency (IEA), International Energy Agency. Southeast Asia Energy Outlook. World Energy Outlook Spec Rep 2013:131. doi:10.1787/weo2013-en.

[77] IRENA. Geothermal Power: Technology Brief. Int Renew Energy Agency 2017:111-3.

[78] Woodhouse M, Jones-Albertus R, Feldman D, Fu R, Horowitz K, Chung D, et al. On the Path to SunShot: The Role of Advancements in Solar Photovoltaic Efficiency, Reliability, and Costs. Natl Renew Energy Lab 2016:44. doi:NREL/TP-6A20-65872.

[79] International Energy Agency, IEA. Energy Technology Perspectives 2017. OECD; 2017. doi:10.1787/energy_tech-2017-en.

[80] Veldhuis AJ, Reinders AHME. Reviewing the potential and cost-effectiveness of off-grid PV systems in Indonesia on a provincial level. Renew Sustain Energy Rev 2015;52:757-69. doi:10.1016/j.rser.2015.07.126.

[81] Kennedy S. Indonesia's energy transition and its contradictions: emerging geographies of energy, finance, and land use. Energy Res Soc Sci 2018:0-1. doi:10.1016/J.ERSS.2018.04.023.

[82] International Renewable Energy Agency (IRENA). Renewable Energy Prospects: Indonesia. REmap 2030, Abu Dhabi: 2017, p. 106. doi:10.1145/347642.347800.

[83] Fthenakis VM, Kim HC, Alsema E. Emissions from Photovoltaic Life Cycles. Environ Sci Technol 2008;42:2168-74. doi:10.1021/es071763q.

[84] Barron-Gafford GA, Minor RL, Jojola J, Barnett-Moreno I, Martinez C, Thompson MS, et al. Dryland Agrivoltaics: A novel approach to collocating food production and solar renewable energy to maximize food production, water savings, and energy generation 2018.

[85] Swamy MK, Sinniah UR. Patchouli (Pogostemon cablin Benth.): Botany, agrotechnology and biotechnological aspects. Ind Crops Prod 2016;87:161-76. doi:10.1016/j.indcrop.2016.04.032.

[86] Arpi N, Erika C, Ermaya D. Survey and study on yield and quality of patchouli oil in Aceh Barat Daya District, Indonesia based on original area of raw materials , methods and length of distilation 2011;1:22-7.

[87] Ginting L. BUDIDAYA TANAMAN NILAM: YANG BAIK DAN BENAR 2017.

[88] Misra M. Growth, photosynthetic pigment content and oil yield of Pogostemon cablin grown under sun and shade conditions. Biol Plant 1995;37:219-23. 
doi:10.1007/BF02913216.

[89] Hsu DD, O'Donoughue P, Fthenakis V, Heath GA, Kim HC, Sawyer P, et al. Life Cycle Greenhouse Gas Emissions of Crystalline Silicon Photovoltaic Electricity Generation. J Ind Ecol 2012;16:S122-35. doi:10.1111/j.1530-9290.2011.00439.x.

[90] Costanza R. Embodied Energy and Economic Valuation. Science (80- ) 1980;210:1219-24. doi:10.1126/science.210.4475.1219.

[91] Fan J. Performance of Nine Different Types of PV Modules in the Tropical Region. Int J Electr Comput Energ Electron Commun Eng 2014;8:1407-10.

[92] Ramya HG, Palanimuthu V, Rachna S. An introduction to patchouli (Pogostemon cablin Benth.) - A medicinal and aromatic plant: It's importance to mankind. Agric Eng Int CIGR J 2013;15:243-50.

[93] Swamy MK, Mohanty SK, Sinniah UR, Maniyam A. Evaluation of Patchouli ( Pogostemon cablin Benth.) Cultivars for Growth, Yield and Quality Parameters. J Essent Oil Bear Plants 2015;18:826-32. doi:10.1080/0972060X.2015.1029989.

[94] Yunus M. Process Design Of Patchouli Oil Distillation By Varying Operating Conditions To Increase Yeild Of Patchouli Oil 2006;i:1-5.

[95] Ramachandra KM, Vasundhara M, Farooqi AA, Srinivasappa KN. Effect of varieties and spacings on growth, yield and quality of patchouli (Pogostemon patchouli Pellet.). J Spirces Aromat Crop 2003;12:43-6.

[96] Singh M, Sharma S, Ramesh S. Herbage, oil yield and oil quality of patchouli [Pogostemon cablin (Blanco) Benth.] influenced by irrigation, organic mulch and nitrogen application in semi-arid tropical climate. Ind Crops Prod 2002;16:101-7. doi:https://doi.org/10.1016/S0926-6690(02)00013-4.

[97] Sulaiman DH. Extraction of Patchouli Oil Using Steam Distillation 2008.

[98] Singh RR, Singh RR, Soni SK, Singh SP, Chauhan UK, Kalra A. Vermicompost from biodegraded distillation waste improves soil properties and essential oil yield of Pogostemon cablin (patchouli) Benth. Appl Soil Ecol 2013;70:48-56. doi:10.1016/j.apsoil.2013.04.007.

[99] Ito M, Kato K, Komoto K, Kichimi T, Kurokawa K. A comparative study on cost and life-cycle analysis for $100 \mathrm{MW}$ very large-scale PV (VLS-PV) systems in deserts using m-Si, a-Si, CdTe, and CIS modules. Prog Photovoltaics Res Appl 2008;16:17-30. doi:10.1002/pip.770.

[100] García-Valverde R, Miguel C, Martínez-Béjar R, Urbina A, Bhattacharya SC. Life cycle assessment study of a $4.2 \mathrm{~kW}$ p stand-alone photovoltaic system 2009 . doi:10.1016/j.solener.2009.03.012.

[101] Joint Crediting Mechanism of Indonesia Secrtariat. Emission Factor 2017. http://jcm.ekon.go.id/en/index.php/content/Mzg\%253D/emission_factor (accessed 
October 25, 2018).

[102] Ginting L. Interview 2017.

[103] Ramya HG. Study on steam distillation of patchouli (Pogostemon cablin Benth.) and utilization of the by-product spent leaves. University of Agricultural Sciences, 2010 .

[104] Yan X, Tan DKY, Inderwildi OR, Smith JAC, King DA. Life cycle energy and greenhouse gas analysis for agave-derived bioethanol. Energy Environ Sci 2011;4:3110. doi:10.1039/c1ee01107c.

[105] Utama A, Gheewala SH. Life cycle energy of single landed houses in Indonesia. Energy Build 2008;40:1911-6. doi:10.1016/j.enbuild.2008.04.017.

[106] Park S, Jang J, Hidayat W, Qi Y, Febrianto F, Kim N. Combustion properties of major wood species planted in Indonesia. J Korean Wood Sci Technol 2015;43:768-76.

[107] Mulyadi A. Interview 2017.

[108] You Z, Marutani M, Borthakur D. Diversity among Bradyrhizobium isolates nodulating yardlong bean and sunnhemp in Guam. J Appl Microbiol 2002;93:57784. doi:10.1046/j.1365-2672.2002.01733.x.

[109] Indah S. Feasibility analysis of patchouli cultivation business (Pogostemon calbin) [in Bahasa Indonesia]. Institut Pertanian Bogor, 2010.

[110] Hermawan A, Rochdiani D, Hardiyanto T. Analysis of healthy long beans (Vigna sinensis L.) Parade varieties (Case Study in Kelurahan Pataruman, Pataruman SubDistrict, Banjar City) [in Bahasa Indonesia]. J Ilm Mahsiswa 2015;1:77-82.

[111] Asdrubali F, Baldinelli G, D’Alessandro F, Scrucca F. Life cycle assessment of electricity production from renewable energies: Review and results harmonization. Renew Sustain Energy Rev 2015;42:1113-22. doi:10.1016/j.rser.2014.10.082.

[112] Baker McKenzie. Indonesian Government Publishes 2017 Cost of Generation (BPP) Figures. Jakarta: 2018.

[113] Spalding-Fecher R. Health benefits of electrification in developing countries: a quantitative assessment in South Africa. Energy Sustain Dev 2005;9:53-62. doi:10.1016/S0973-0826(08)60482-2.

[114] Zahnd A, Kimber HM. Benefits from a renewable energy village electrification system. Renew Energy 2009;34:362-8. doi:10.1016/j.renene.2008.05.011.

[115] NREL. 2017 ATB Cost and Performance Summary 2017. https://atb.nrel.gov/electricity/2017/summary.html (accessed October 25, 2018).

[116] Taufiqurrohman I. The Assessment of Off-Grid Photovoltaic (PV) Systems for 
Rural Electrification in Indonesia. SSRN Electron J 2018:1-6. doi:10.2139/ssrn.3201095.

[117] Shukla J, Nobre C, Sellers P. Amazon Deforestation and Climate Change. Science (80- ) 1990;247:1322-5.

[118] Bosetti V, Lubowski R, editors. Deforestation and Climate Change. Edward Elgar Publishing; 2010.

[119] Tomich T. Agricultural intensification, deforestation, and the environment: assessing tradeoffs in Sumatra, Indonesia. Tradeoffs or Synerg Agric Intensification, Econ Dev Environ 2001. doi:10.1079/9780851994352.0221.

[120] Lambin EF, Geist HJ, Lepers E. Dynamics of Land-Use and Land-Cover Change in Tropical Regions. Annu Rev Environ Resour 2003;28:205-41. doi:10.1146/annurev.energy.28.050302.105459.

[121] Carlson KM, Curran LM, Ratnasari D, Pittman AM, Soares-Filho BS, Asner GP, et al. Committed carbon emissions, deforestation, and community land conversion from oil palm plantation expansion in West Kalimantan, Indonesia. Proc Natl Acad Sci 2012;109:7559-64.

[122] Breyer C, Bogdanov D, Aghahosseini A, Gulagi A, Child M, Oyewo AS, et al. Solar photovoltaics demand for the global energy transition in the power sector. Prog Photovoltaics Res Appl 2018;26:505-23. doi:10.1002/pip.2950.

[123] Lavigne F, Gunnell Y. Land cover change and abrupt environmental impacts on Javan volcanoes, Indonesia: a long-term perspective on recent events. Reg Environ Chang 2006;6:86-100. doi:10.1007/s10113-005-0009-2. 


\section{APPENDICES}

The following are the R scripts that make up the LCA models. Each bold title is the name of the script, followed by the contents of the script.

\section{A. THE INPUT SCRIPT FOR THE LCA MODELS}

\#Script A: Input variables

\#Script A contains the input variables for the modeling of the material inputs and outputs \#of patchouli harvest and distillation.

\#Based on the material inputs and outputs, life cycle energy inputs/outputs, carbon footprint,

\#and cash flow and NPV are generated. The last part of this model includes sensitivity and

\#Monte Carlo analyses, which should yield a range of all the environmental and economic

\#performance parameters, except for cash flow.

\#Presets

script.dir <- dirname(sys.frame(1)\$ofile) \#saves the path of the source file.

\#This part of the script only works when you run source and not just the line.

setwd(script.dir) \#sets the working directory to the current path of the source file.

requiredpackages <- c("FinancialMath", "FinCal", "tidyverse", "triangle","maps","mapdata","readxl","googleVis", "ggthemes","ggrepel","cowplot")

\# this can be any number of packages inside the character vector.

for (pkg in requiredpackages) \{

if $(\mathrm{pkg} \% \mathrm{in} \%$ rownames(installed.packages ()$)==\mathrm{FALSE})$

install.packages $(\mathrm{pkg})\}$

if $($ pkg \% in \% rownames $($.packages ()$)==$ FALSE $)$

$\{$ library(pkg,character.only = TRUE) $\}$ \#\#the "character.only" argument is essential \}

\#1. INPUT VARIABLES

\#Input variables can be classified as follows: Patchouli cultivation and distillation variables,

\#economic variables, carbon variables, and energy variables.

\#Patchouli cultivation and distillation variables concern themselves with the material inputs

\#and outputs of the patchouli.

\#Economic variables concern themselves with the cost of the materials, labor, and \#auxiliary items required for determining cash flow and NPV.

\#Carbon variables are the embodied carbon dioxide equivalent of the materials and fuels \#used in the patchouli Patchouli cultivation and distillation. 
\#Energy variables are the embodied energy of the materials and fuels used in the \#patchouli Patchouli cultivation and distillation.

\section{\#1.1 Input variables: Material}

\#1.1.1 Land use: Patchouli cultivation and distillation

\#'proj_period' is the length of the project in years.

\#'build_lifetime' is the economic lifetime of the building for the patchouli processing unit, which is set to 10 years.

\#'distil_lifetime' is the economic lifetime of the patchouli distillation unit, which is set to 10 years.

\#'land' is the area of land available for the project (large scale), which is set

\#to 10 hectares so that 5 hectares can be used to cultivate patchouli for two years, \#while corn is cultivated in the other 5 hectares.

\#It is estimated that 5 ha are required to produced enough patchouli to keep a distillation \#plant running all year. Patchouli crop is rotated with corn, which enriches the soil depleted

\#by patchouli cultivation. Therefore, total land required is 10 ha, with only 5 ha used

\#for patchouli growth at a time.

\#'pat land' is half the area of the available land ('land') that is dedecated to \#cultivating patchouli.

\#'mai_land' is the half the area of the available land ('land') that is dedecated to \#cultivating corn.

\#'plants' is the number of plants pre hectare. Based on the spacing, the number of plants may

\#vary from 10000 in a fertile soil to 20000 in less fertile soils. Base case set to 20000. \#'surv_rate_recip' is the reciprocal of the survival rate $(90 \%)$ of the patchouli seedlings. \#It is multiplied with the number of plants that can be fit into a hectare to find the number \#of patchouli seedlings required per hectare.

\#'seed_prod' is the number of seedlings (20) that can be cultivated from a plant per harvest.

\#'econ_life' is the economic life of the patchouli crop, which may vary from 18 months to \#36 months. As a base case, an economic life of 24 months is assumed

\#'mat' is the age to maturity, at which the first harvest occurs. Age is in months.

\#Age to maturity includes a 2-month seedling stage under a shade and a 5-month

\#'harv_int' is the harvest interval, which may be 3-4 months.

\#'fresh_harv' is the fresh yield per plant per harvest in kg plant $^{\wedge}-1$ harv $^{\wedge}-1$

\#'fresh_dry_ratio' refers to the mass ratio, which is $4: 1$

\#'dry_harv' is the dry yield per plant per harvest in kg plant $^{\wedge}-1$ harv $^{\wedge}-1$

\#'harvest1' is the number of harvests in the first year

\#'harvest2' is the number of harvests in the second year

\#'harvest 3 ' is the number of harvests in the third year

\#'yield1' refers to the dry yield in the first year of the harvest.

\#'yield2' refers to the dry yield in the second year of the harvest.

\#'yield3' refers to the dry yield in the third year of the harvest.

proj_period $<-30$ \#years

build_lifetime $<-10$ \#years

distil_lifetime $<-10$ \#years

land $\overline{<}-5$ \#ha 


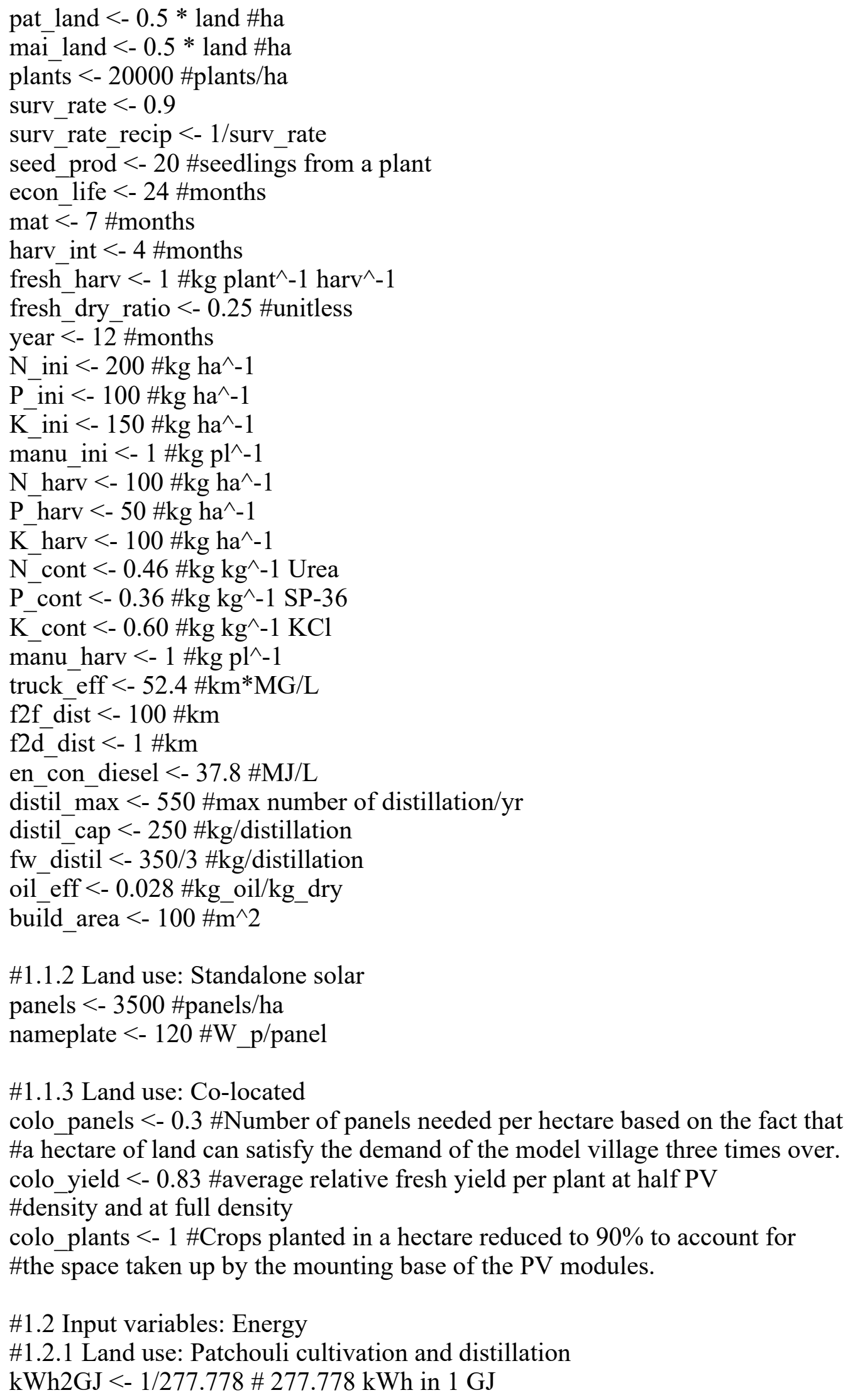


build_unit_energy $<-227.12 \# \mathrm{kWh} \mathrm{m}^{\wedge} 2$

distil_unit_en $<-2900 \# \mathrm{kWh} /$ unit

dies_prim_en_content $<-10.5$ \#kWh/1

dies emb en $<-1.15 \# \mathrm{kWh} / \mathrm{kWh}$ dies

N_energy $<-15.8$ \#kWh $/ \mathrm{kgavg}$

$\mathrm{P}$ _energy $<-2.6 \# \mathrm{kWh} / \mathrm{kg}$

K_energy $<-1.9 \# \mathrm{kWh} / \mathrm{kg}$

fw_en_cont $<-4.086 \# \mathrm{kWh} / \mathrm{kg}$

boiler_eff $<-0.017$ \#unitless

\#1.2.2 Land use: Standalone solar

avg_daily_irr $<-5 \# \mathrm{kWh} / \mathrm{m}^{\wedge} 2 /$ day

avg_ann_irr $<-1825 \# \mathrm{kWh} / \mathrm{m}^{\wedge} 2 / \mathrm{yr}$

eff_PV $\overline{<-} 0.15$ \#unitless

pr $<-0.75$ \#unitless

module_emb_en $<-8.7036 \# \mathrm{kWh} / \mathrm{Wp}$

\#1.2.3 Land use: Co-located

build_unit_energy

distil_unit_en

dies_prim_en_content

dies_emb_en

N_energy

P_energy

K_energy

fw_en_cont

boiler_eff

avg_daily_irr

avg_ann_irr

eff_PV

$\mathrm{pr}$

module emb en

\#1.3 Input variables: GHG

\#1.3.1 Land use: Patchouli cultivation and distillation

$\mathrm{kg} 2 \mathrm{Mg}<-1 / 1000 \# 1000 \mathrm{~kg}$ in $1 \mathrm{Mg}$

build_em_ghg $=178 \# \mathrm{~kg}$ CO_2_eq $/ \mathrm{m}^{\wedge} 2$

build_unit_ghg <- build_em_ghg $*$ build_area \#kg CO_2_eq/building

dies_ghg $<-3.25 \# \mathrm{~kg} \_\mathrm{CO} \_2$ eq $1^{\wedge}-1$

N_ghg $<-11$ \#kg_CO_2_eq $\overline{\mathrm{kg}^{\wedge}-1}$

P_ghg $<-1.61$ \#kg_CO__ 2 _eq $\mathrm{kg}^{\wedge}-1$

K_ghg $<-0.71 \# \mathrm{kWh}$

distil_unit_ghg $<-1000 \# \mathrm{~kg}$ CO_2_eq/unit

fw_gh $<<-23.41 \# \mathrm{~kg}$ CO_2 $/ \mathrm{kg} \mathrm{fw}$

grid_emm_fac $<-0.782$ \#kg_CO_2_eq/kWh

\#1.3.2 Land use: Standalone solar

ghg_per_output $<-0.045 \# \mathrm{~kg} \_\mathrm{CO} \_2$ Eq kWh^${ }^{\wedge} 1$ 


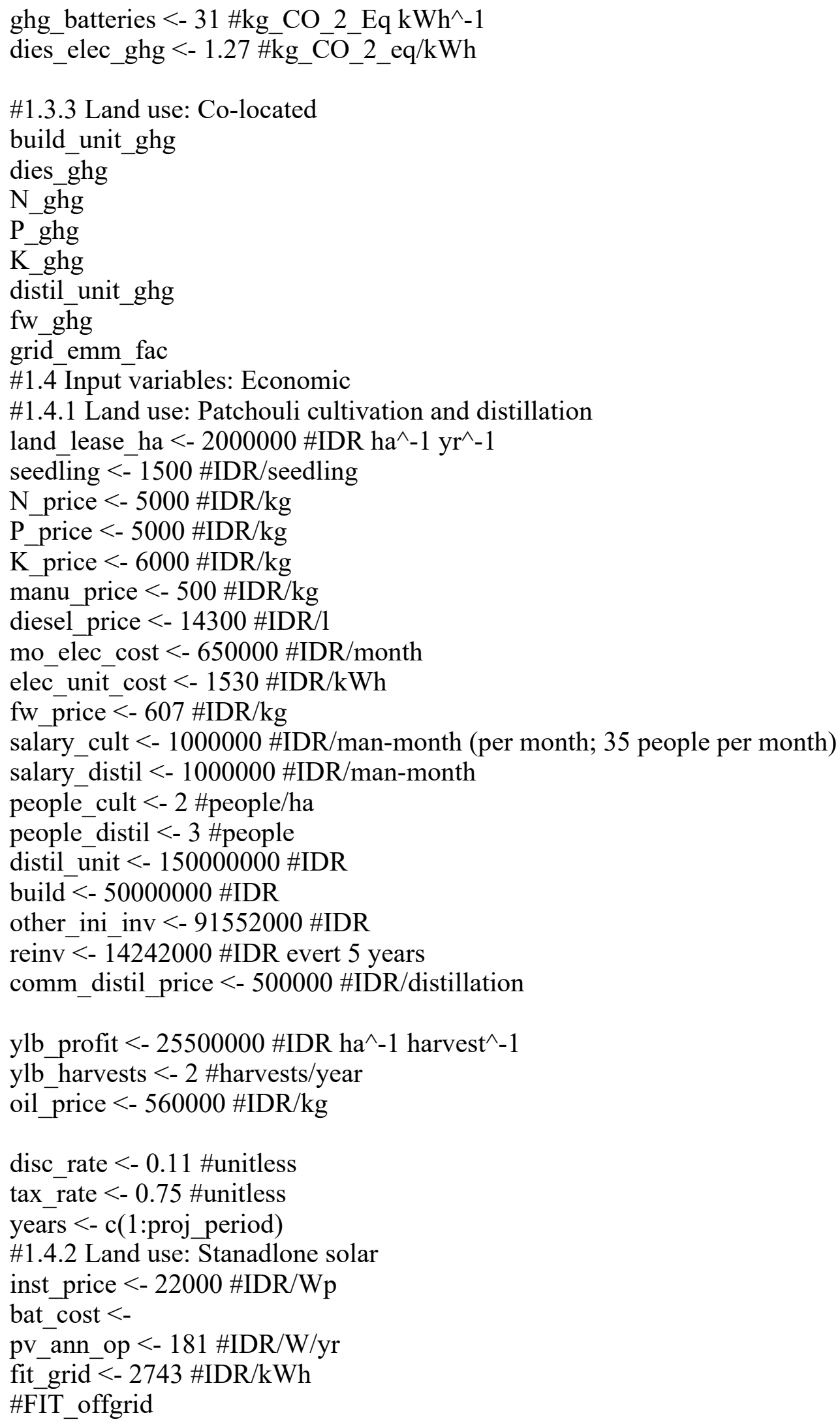


\#1.4.3 Land use: Co-located

outputnames <- c("D_Standalone_Patchouli_12_26_2018.r", "C_Standalone_PV_12_26_2018.r",

"E_colocated_12_26_2018.r",

"Graphics_12_26_2018.r",

\# "Graphics_11_14 1 2018.r", "Sankey_12_26_2018.r")

for (i in outputnames) \{

source(i)

\} 


\section{B. THE LIFE CYCLE ANALYSIS MODEL OF SOLAR PV LAND USE}

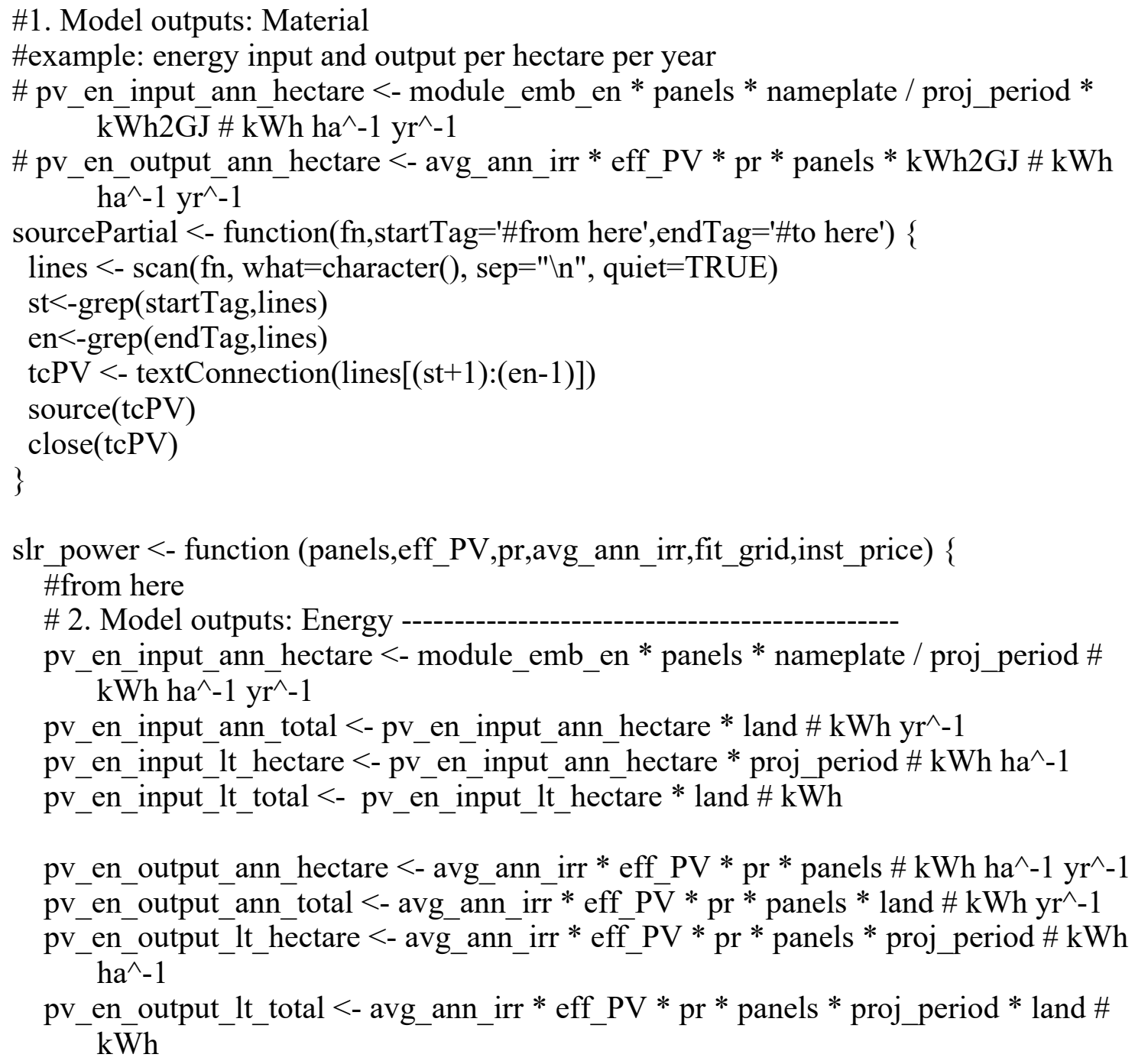

pv_en_output_ann_hectare $<-$ avg_ann_irr * eff_PV * $\mathrm{pr}^{*}$ panels \# $\mathrm{kWh}$ ha ${ }^{\wedge}-1 \mathrm{yr}^{\wedge}-1$ pv_en_output_ann_total $<-$ avg_ann_irr $*$ eff_PV $*$ pr * panels * land $\# \mathrm{kWh} \mathrm{yr}^{\wedge}-1$ pv_en_output_lt_hectare $<-$ avg_ann_irr * eff_PV * pr * panels * proj_period \# $\mathrm{kWh}$ $\mathrm{ha}^{\wedge}-1$

pv_en_output_lt_total $<-$ avg_ann_irr * eff_PV * pr * panels * proj_period * land \# $\mathrm{kWh}$

\# 3. Model outputs: GHG

pv_ghg_ann_hectare $<-$ ghg_per_output * pv_en_output_ann_hectare \# kg_CO_2_eq $\mathrm{ha}^{\wedge}-1 \mathrm{yr}^{\wedge}-1$

pv_ghg_ann_total $<-$ ghg_per_output * pv_en_output_ann_total \# $\mathrm{kg} \_\mathrm{CO} \_2$ Eq $\mathrm{yr}^{\wedge}-1$ pv_ghg_lt_hectare $<-$ ghg_per_output * pv_en_output_lt_hectare \# kg_CO_2 2 Eq ha ${ }_{-}$ 1

pv_ghg_lt_total <-ghg_per_output * pv_en_output_lt_total \# kg_CO_2_Eq

pv_dies_unit_offset $<-$ dies_elec_ghg - ghg_per_output \# $\mathrm{kg} \_C O \_2$ _eq $\mathrm{kWh} \mathrm{H}^{\wedge}-1$

pv_dies_offset_ann_hectare $<$ - pv_dies_unit_offset $*$ pv_en_output_ann_hectare \# $\mathrm{kg} \_\mathrm{CO} 2$ _eq $\mathrm{ha}^{\wedge}-1 \mathrm{yr}^{\wedge}-1$

pv_dies_offset_ann_total $<-$ pv_dies_unit_offset * pv_en_output_ann_total \# $\mathrm{kg} \_\mathrm{CO} \_2$ Eq $\mathrm{yr}^{\wedge}-1$

pv_dies_offset_lt_hectare $<-$ pv_dies_unit_offset * pv_en_output_lt_hectare \# kg_CO_2_Eq ha ${ }^{\wedge}-1$ 
pv_dies_offset_lt_total $<-$ pv_dies_unit_offset * pv_en_output_lt_total \# kg_CO_2_Eq

pv_grid_unit_offset $<$-grid_emm_fac - ghg_per_output \# $\mathrm{kg} \_\mathrm{CO} \_2$ _eq $\mathrm{kWh} \mathrm{W}^{\wedge}-1$

pv_grid_offset_ann_hectare $<-$ pv_grid_unit_offset $*$ pv_en_output_ann_hectare \# $\mathrm{kg} \_\mathrm{CO} 2$ - eq $\mathrm{ha}^{\wedge}-1 \mathrm{yr}^{\wedge}-1$

pv_grid_offset_ann_total <- pv_grid_unit_offset * pv_en_output_ann_total \# kg_CO_2_Eq $\mathrm{yr}^{\wedge}-1$

pv_grid_offset_lt_hectare $<-$ pv_grid_unit_offset* pv_en_output_lt_hectare \# $\mathrm{kg}$ CO 2 - Eq ha ${ }^{\wedge}-1$

pv_grid_offset_lt_total $<-$ pv_grid_unit_offset * pv_en_output_lt_total \# kg_CO_2_Eq

\# 4. Model outputs: Economic

grid_tied_invest_hectare $<$ - inst_price * panels * nameplate

grid_tied_invest_total $<-$ inst_price * panels * nameplate * land

ann_op_hectare $<-$ pv_ann_op * panels * nameplate

ann_op_total <- pv_ann_op $*$ panels $*$ nameplate $*$ land

ann_fit_grid_hectare $<-$ pv_en_output_ann_hectare * fit_grid

ann_fit_grid_total $<-$ pv_en_output_ann_total * fit_grid

\# 5. Net present value at the end of the project period

PV_lg_inflow $<-$ c(rep(ann_fit_grid_total,proj_period $))$

PV_lg_outflow $<-$ c(rep(ann_op_total,proj_period $))$

cf_PV_lg $<-$ PV_lg_inflow - PV_lg_outflow

cf_PV_lg_tx $<-$ cf_PV_lg $*$ tax_rate

$\mathrm{NP} \bar{P} \overline{\mathrm{P} V} \_\mathrm{lg}<-\mathrm{NPV}$ (grid_tied_invest_total,cf_PV_lg_tx,years,disc_rate,plot=FALSE) \#NPV too large

\#to here

return(c(pv_en_input_ann_hectare, pv_en_output_ann_hectare,

pv_ghg_ann_hectare,

pv_dies_offset_ann_hectare,

pv_grid_offset_ann_hectare,

\}

NPV_PV_lg))

\#6. Summaries

run $=10000$

solarsummary $<-$ matrix $($ data $=\mathrm{NA}$, nrow $=$ run, $\mathrm{ncol}=6)$

for (i in 1:run) \{

panels $<$ - rtriangle $(1,2500,3500)$

eff_PV $<$-rtriangle $(1,0.14,0.16)$

$\mathrm{pr}<-$ rtriangle $(1,0.749,0.767)$

avg_ann_irr $<$-rtriangle $(1,1752,1898)$

fit_grid $<$-rtriangle $(1,1750,2250)$

inst_price $<$ - rtriangle $(1,25000,35000)$

solarsummary $[\mathrm{i}]<$,- slr_power(panels,eff_PV,pr,avg_ann_irr,fit_grid,inst_price) \} 
write.csv(solarsummary,'solarsummary.csv') 


\section{THE LIFE CYCLE ANALYSIS MODEL OF PATCHOULI CULTIVATION AND DISTILLATION LAND USE}

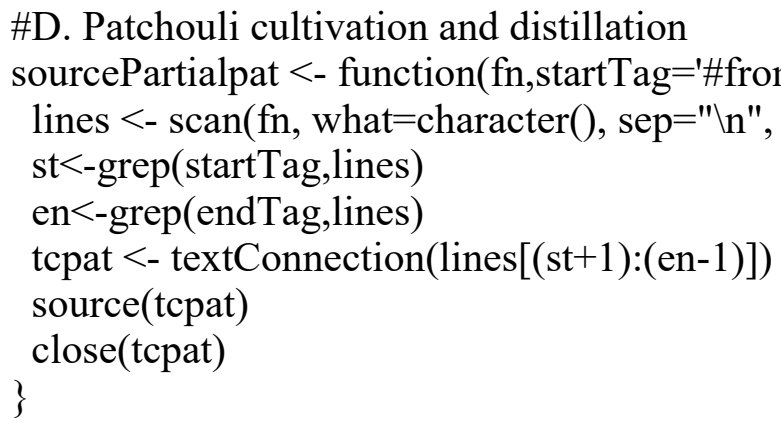




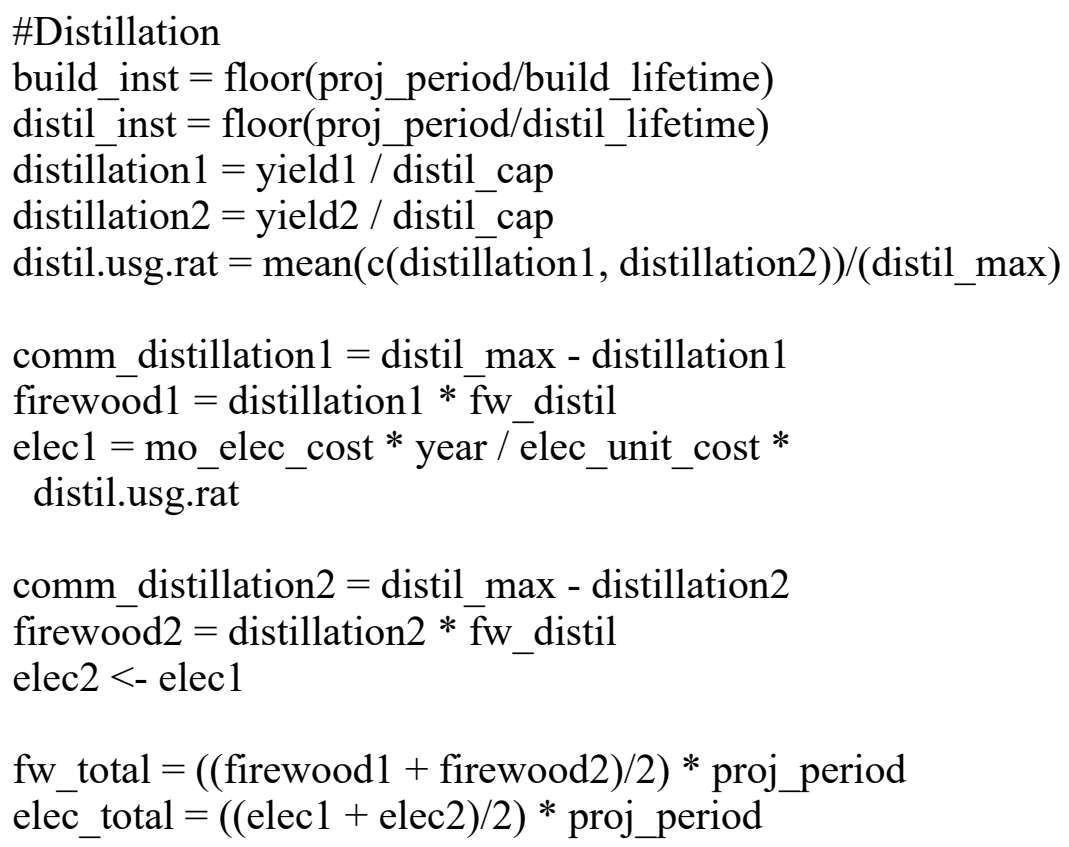




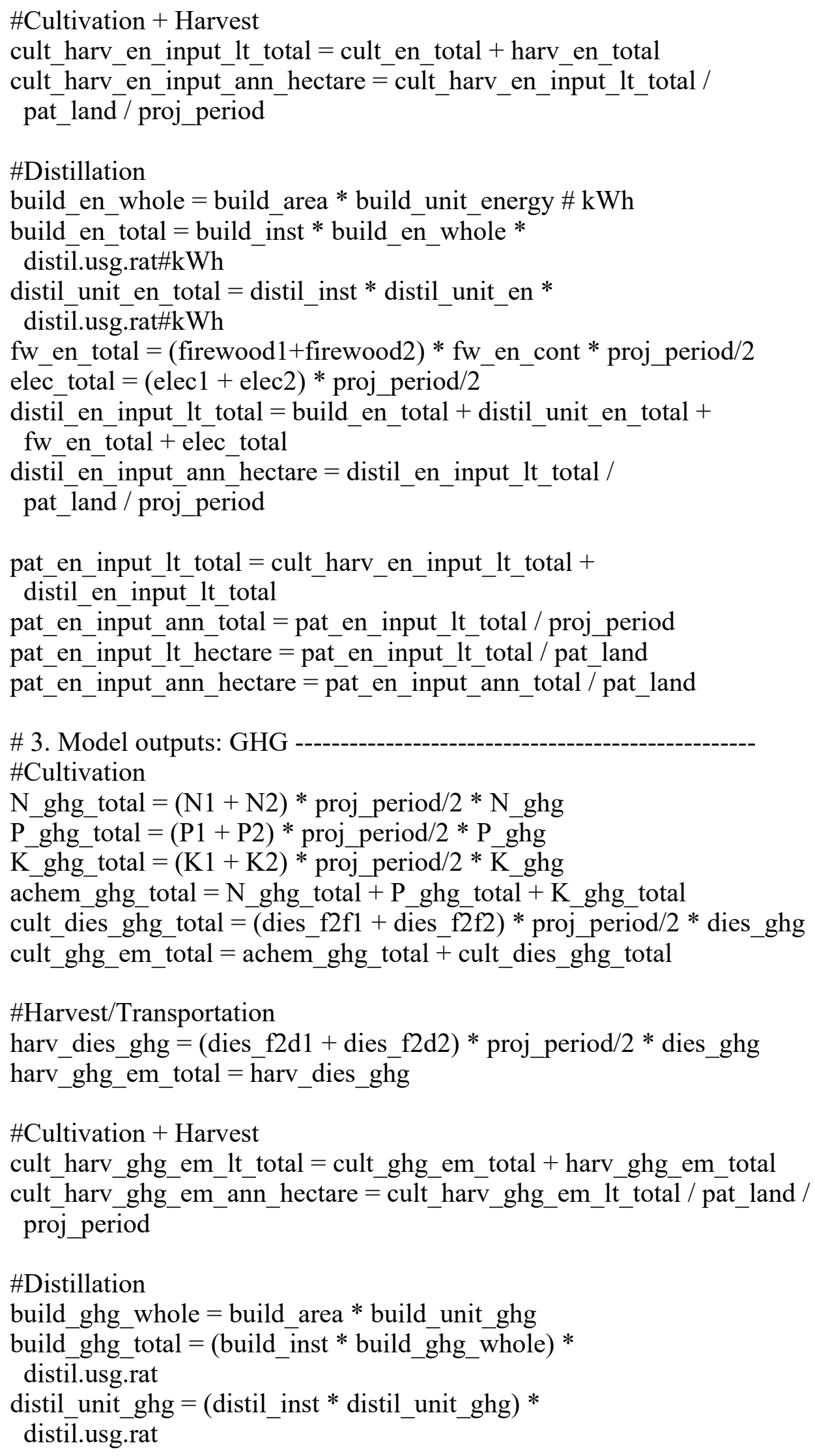


elec_ghg_total $=($ elec $1+$ elec 2$) *$ proj_period $/ 2 *$ grid_emm_fac fw_ghg_total $=($ firewood $1+$ firewood 2$) *$ fw_ghg $*$ proj_period $/ 2$

distil_ghg_em_lt_total = build_ghg_total + distil_unit_ghg +

elec_ghg total $+\mathrm{fw}$. ghg total

distil_ghg_em_ann_hectare $=$ distil_ghg_em_lt_total / pat_land / proj_period

pat_ghg_em_lt_total = cult_harv_ghg_em_lt total + distil_ghg_em_lt_total

pat_ghg_em_lt_hectare $=$ pat_ghg_em_lt_total $/$ pat_land

pat_ghg_em_ann_total $=$ pat_ghg_em_lt_total $/$ proj_period

pat_ghg_em_ann_hectare $=$ pat_ghg_em_ann_total / pat_land

\# 4. Model outputs: Economic

land_lease_total $=$ land_lease_ha $*$ proj_period $*$ land

seed_cost $=$ seedling $* \overline{\text { plants }}{ }^{*}$ surv_rate_recip

cost_achem $1=\mathrm{N} 1 * \mathrm{~N} \_$price $+\mathrm{P} 1 * \mathrm{P} \_$price $+\mathrm{K} 1 * \mathrm{~K} \_$price + manu $1 *$ manu_price

cost_achem $2=\mathrm{N} 2 * \mathrm{~N} \_$price $+\mathrm{P} 2 * \mathrm{P} \_$price $+\mathrm{K} 2 * \mathrm{~K} \_$price + manu $2 *$ manu_price

diesel_cost $1=(\operatorname{dies} \mathrm{f} 2 \mathrm{f} 1+$ dies_f2d1 $) *$ diesel_price

diesel_cost $2=($ dies_f2f2 + dies_f2d 2$) *$ diesel_price

cult_labor $=$ people_cult $*$ salary_cult $*$ year

$\mathrm{fw} \_\cos 1 \mathrm{l}=$ firewood $1 * \mathrm{fw} \_$price

$\mathrm{fw} \_$cost $2=$ firewood $2 *$ fw_price

elec_cost $=$ mo_elec_cost * year \#assumes the distillation facility is run year-round, \#even before the maturity of the patchouli plants by taking in distillation materials from other farms.

distil_labor $=$ people_distil $*$ salary_distil $*$ year

oil_rev1 $=$ oil_yield $1 *$ oil_price

oil_rev2 $=$ oil_yield $2 *$ oil_price

labor_total $=$ cult_labor + distil_labor

ylb_profit ann $=y l b \_$profit $*$ ylb harvests * mai land

comm distil rev1 $=$ comm distillation $1 *$ comm distil price $^{-}$

comm_distil_rev2 $=$ comm_distillation $2 *$ comm_distil_price

\# 5. Net present value at the end of the project period

pch invest $=$ land lease total + build $*$ distil.usg.rat +

distil_unit * distil.usg.rat + other_ini_inv + seed_cost

pch_inflow_a $=$ rep(coil_rev1 + ylb_profit_ann,

oil_rev2 + ylb_profit_ann),proj_period/2)

pch_outflow_a $=$ rep $\left(\mathrm{c}\left(\mathrm{cost}\right.\right.$ _achem $1+\mathrm{fw} \_$cost $1+$ diesel_cost $1+$ labor_total+elec_cost,

cost_achem2+fw_cost2+diesel_cost2+labor_total+elec_cost),proj_period/2)

pch_outflow_b $=\mathrm{c}(0,0,0,0,0$, reinv, $0,0,0,0$, reinv+build * distil.usg.rat + distil_unit * distil.usg.rat, $0,0,0,0$, reinv, $0,0,0,0$, 


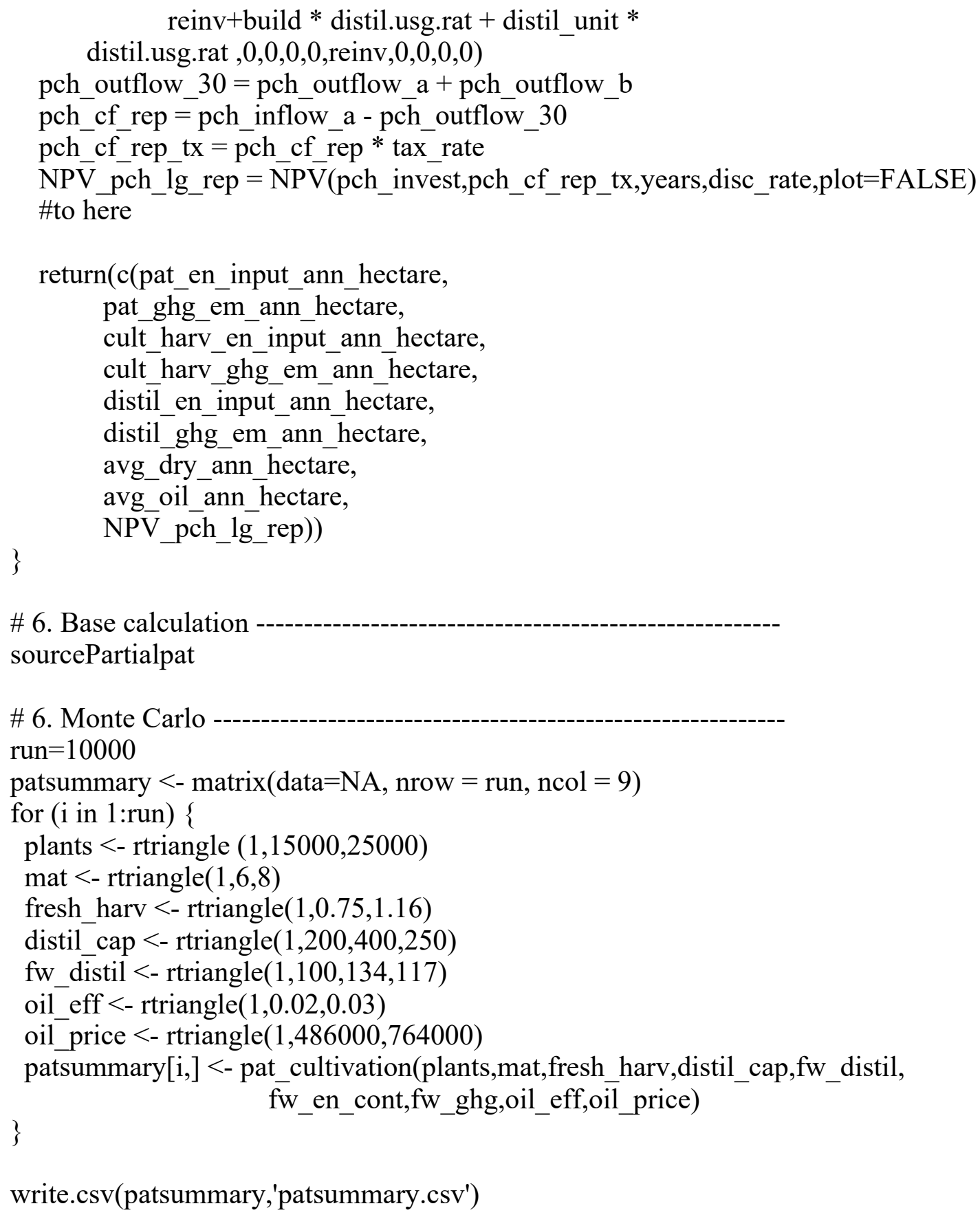




\section{THE LIFE CYCLE ANALYSIS MODEL OF CO-LOCATED PV-PATCHOULI CO- LOCATION}

\#E Co-located land use

\#This script calculates the NPV of co-located land-use as a sum of fraction of \#agricultural and photovoltaic productivity from the single land uses.

\#This script first calls the functions from the stand-alone land use scripts, \#reduces the economic productivity by a fraction, and adds the NPVs resulting \#from the two land-uses.

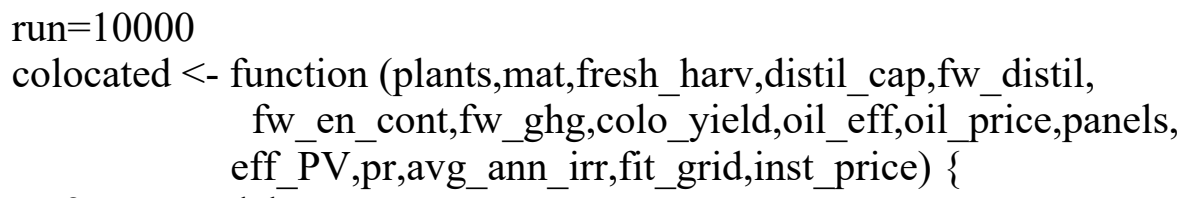

pv_en_output_ann_hectare $<-$ avg_ann_irr * eff_PV * pr * panels \# $\mathrm{kWh} \mathrm{ha} \mathrm{h}^{\wedge}-1 \mathrm{yr}^{\wedge}-1$ pv_en_output_ann_total $<-$ avg_ann_irr * eff_PV $* \mathrm{pr}^{*}$ panels * land \# $\mathrm{kWh} \mathrm{yr}^{\wedge}-1$ pv_en_output_lt_hectare $<-$ avg_ann_irr * eff_PV * pr * panels * proj_period \# kWh $\mathrm{ha}^{\wedge}-1$

pv_en_output_lt_total $<-$ avg_ann_irr * eff_PV * pr * panels * proj_period * land \# $\overline{\mathrm{kWh}}$

\# 3. PV Model outputs: GHG

pv_ghg_ann_hectare $<-$ ghg _per_output * pv_en_output_ann_hectare \# kg_CO_2_eq $\mathrm{ha}^{\wedge}-1 \mathrm{yr}^{\wedge}-1$

pv_ghg_ann_total $<-$ ghg_per_output * pv_en_output_ann_total \# $\mathrm{kg} \_\mathrm{CO} \_2 \_\mathrm{Eq} \mathrm{yr}^{\wedge}-1$

pv_ghg_lt_hectare $<-$ ghg_per_output * pv_en_output_lt_hectare \# kg_CO_2 Eq ha^-1

pv_ghg_lt_total $<-$ ghg_per_output * pv_en_output_lt_total \# kg_CO_2_Eq

pv_dies_unit_offset $<-$ dies_elec_ghg - ghg_per_output \# kg_CO_2_eq $\mathrm{kWh}^{\wedge}-1$

pv_dies_offset_ann_hectare $<-$ pv_dies_unit_offset $*$ pv_en_output_ann_hectare \# kg_CO_2_eq $\mathrm{ha}^{\wedge}-1 \mathrm{yr}^{\wedge}-1$

pv_dies_offset_ann_total $<-$ pv_dies_unit_offset * pv_en_output_ann_total \# kg_CO_2_Eq $\mathrm{yr}^{\wedge}-1$

pv_dies_offset_lt hectare $<-$ pv_dies_unit_offset * pv_en_output_lt hectare \# $\mathrm{kg} \mathrm{CO} 2 \mathrm{Eq} \mathrm{ha}{ }^{\wedge}-1$

pv_dies_offset_lt_total $<-$ pv_dies_unit_offset * pv_en_output_lt_total \# kg_CO_2_Eq

pv_grid_unit_offset $<$-grid_emm_fac - ghg_per_output \# $\mathrm{kg} \_C O \_2$ eq $\mathrm{kWh}^{\wedge}-1$ pv_grid_offset_ann_hectare $<-$ pv_grid_unit_offset * pv_en_output_ann_hectare \# kg_CO_2_eq $\overline{\mathrm{ha}}{ }^{\wedge}-1 \mathrm{yr}^{\wedge}-1$ 
pv_grid_offset_ann_total $<-$ pv_grid_unit_offset * pv_en_output_ann_total \# $\mathrm{kg}$ _CO_2_Eq $\mathrm{yr}^{\wedge}-1$

pv_grid_offset_lt_hectare $<-$ pv_grid_unit_offset* $*$ pv_en_output_lt hectare \# kg_CO_2_Eq ha ${ }^{\wedge}-1$

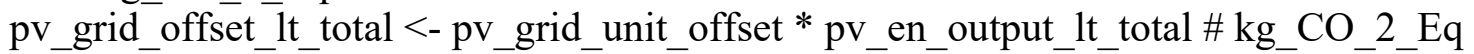

\# 4. PV Model outputs: Economic

grid_tied_invest_hectare $<$ - inst_price * panels * nameplate

grid_tied_invest_total $<-$ inst_price * panels * nameplate $*$ land

ann_op_hectare $<-$ pv_ann_op $*$ panels $*$ nameplate

ann op total $<-$ pv ann op * panels * nameplate * land

ann_fit_grid_hectare $<-\bar{p}$ v_en_output_ann_hectare $*$ fit_grid

ann_fit_grid_total $<-$ pv_en_output_ann_total $*$ fit_grid

\# 1. PCH Model outputs: Material-

harvest $1=$ floor $(($ year-mat $) /$ harv_int +1$)$

harvest $2=$ floor $((2 *$ year-mat-harv_int*(harvest $1-1)) /$ harv_int $)$

$\mathrm{N} 1=$ pat_land $*(\mathrm{~N}$ ini $+\mathrm{N}$ harv $*$ (harvest $1-1))$

$\mathrm{P} 1=$ pat_land $*(\mathrm{P}$ ini $+\mathrm{P}$ harv $*($ harvest $1-1))$

$\mathrm{K} 1=$ pat_land $*(\overline{\mathrm{K}}$ ini $+\overline{\mathrm{K}}$ harv $*($ harvest $1-1))$

manu $1=$ pat_land $*(($ manu_ini + harvest $1 / 2) *$ plants $)$

$\mathrm{N} 2=$ pat_land $*\left(\mathrm{~N} \_\right.$harv $*$ harvest 2$)$

$\mathrm{P} 2=$ pat_land $*(\mathrm{P}$ harv $*$ harvest 2$)$

$\mathrm{K} 2=$ pat_land $*(\overline{\mathrm{K}}$ harv $*$ harvest 2$)$

manu $2=$ pat_land $*($ harvest $2 *$ plants $)$

achem $1=\mathrm{N} 1+\mathrm{P} 1+\mathrm{K} 1+$ manu1 \#kg

dies_f2f1 $=$ achem $1 / 1000 *$ f2f_dist* $(1 /$ truck_eff $)$

achem $2=\mathrm{N} 2+\mathrm{P} 2+\mathrm{K} 2+$ manu 2

dies_f $2 \mathrm{f} 2=$ achem $2 / 1000 * \mathrm{f} 2 \mathrm{f}$ _dist*(1/truck_eff $)$

\#Harvest and transport

fresh_yield $1=$ pat_land $*$ plants $*$ harvest $1 *$ fresh_harv $*$ colo_yield

yield $1=$ pat_land ${ }^{*}$ plants $*$ harvest $1 *$ fresh_harv ${ }^{*}$ fresh_dry_ratio

dies_f2d1 $=$ yield $1 / 1000 *$ f2d_dist $*(1 /$ truck_eff $)$

harv_dies $1=$ dies_f $2 \mathrm{f} 1$

fresh_yield $2=$ pat land $*$ plants $*$ harvest $2 *$ fresh_harv $*$ colo_yield

yield $\overline{2}=$ pat_land $\bar{*}$ plants $*$ harvest $2 *$ fresh_harv ${ }^{*}$ fresh_dry_ratio

dies_f2d $2=$ yield $2 / 1000 *$ f2d_dist $*(1 /$ truck_eff $)$

harv_dies $2=$ dies_f2f2

harv_dies_total $=\left(\left(\operatorname{dies} \_f 2 \mathrm{f} 1+\operatorname{dies\_ f2f2)} / 2\right) *\right.$ proj_period

\#Distillation 


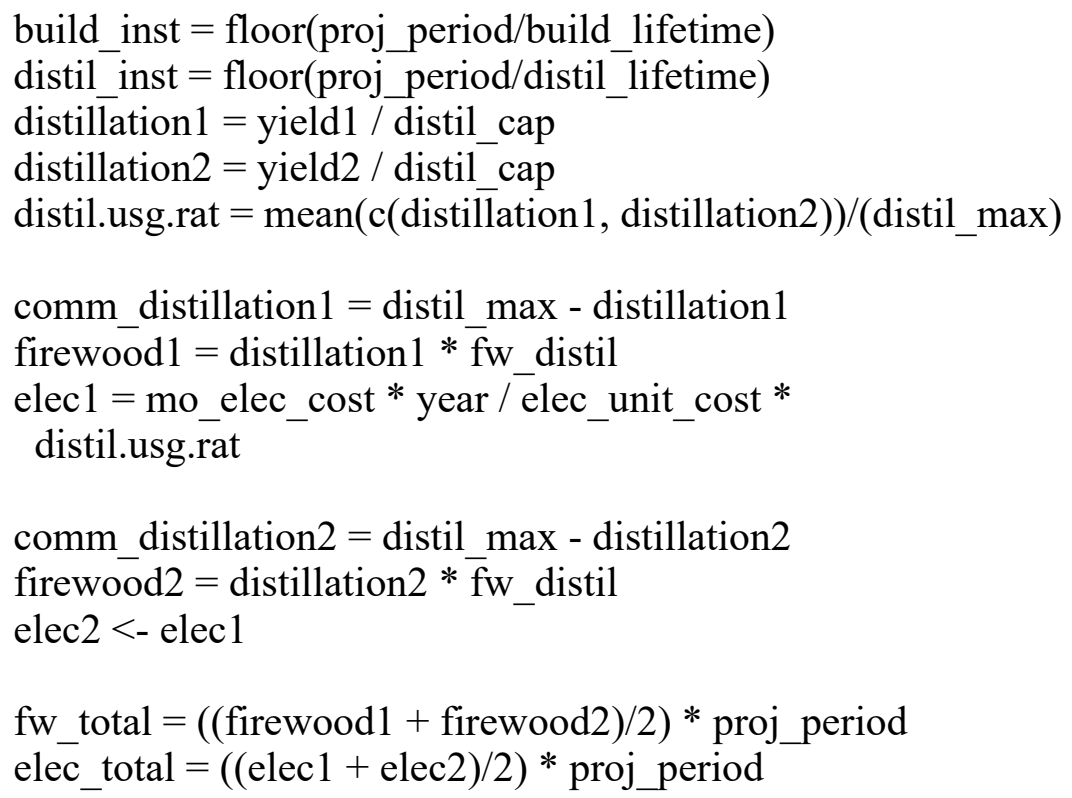


cult_harv_en_input_lt_total $=$ cult_en_total + harv_en_total

cult_harv_en_input_ann_hectare $=$ cult $\overline{-}$ harv_en_input_lt total /

pat_land / proj_period

\#Distillation

build_en_whole $=$ build_area $*$ build_unit_energy \# $\mathrm{kWh}$

build_en_total $=$ build_inst $*$ build_en_whole $*$

distil.usg.rat\#kWh

distil_unit_en_total $=$ distil_inst $*$ distil_unit_en $*$

distil.usg.rat\#kWh

fw_en_total $=($ firewood $1+$ firewood 2$) *$ fw_en_cont $*$ proj_period $/ 2$

elec_total $=($ elec $1+$ elec 2$) *$ proj_period $/ 2$

distil_en_input_lt_total $=$ build_en_total + distil_unit_en_total +

fw_en_total + elec_total

distil_en_input_ann_hectare = distil_en_input_lt_total /

pat_land / proj_period

pat_en_input_lt_total $=$ cult_harv_en_input_lt_total +

distil_en_input_lt_total

pat_en_input_ann_total $=$ pat_en_input_lt_total / proj_period

pat_en_input_lt_hectare $=$ pat_en_input_lt_total $/$ pat_land

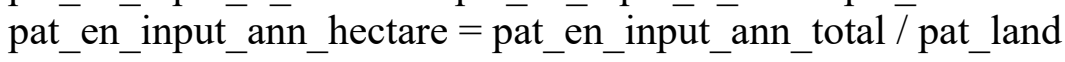

\# 3. PCH Model outputs: GHG

\#Cultivation

N_ghg_total $=(\mathrm{N} 1+\mathrm{N} 2) *$ proj_period $/ 2 * \mathrm{~N}$ ghg

$\mathrm{P}$ ghg total $=(\mathrm{P} 1+\mathrm{P} 2) *$ proj_period $/ 2 * \mathrm{P}$ ghg

$\mathrm{K} \_$ghg_total $=(\mathrm{K} 1+\mathrm{K} 2) *$ proj_period $/ 2 * \overline{\mathrm{K}}$ ghg

achem_ghg_total $=$ N_ghg_total + P_ghg_total + K_ghg_total

cult_dies_ghg_total $=($ dies_f $2 \mathrm{f} 1+\overline{\text { dies_f } 2 \mathrm{f} 2}) * \operatorname{proj\_ period} / 2 *$ dies_ghg

cult_ghg_em_total $=$ achem_ghg_total $\overline{+}$ cult_dies_ghg_total

\#Harvest/Transportation

harv_dies_ghg $=($ dies_f $2 \mathrm{~d} 1+$ dies_f2d 2$) *$ proj_period $/ 2 *$ dies_ghg

harv_ghg_em_total $=\overline{\text { harv_dies_ghg }}$

\#Cultivation + Harvest

cult_harv_ghg_em_lt_total $=$ cult_ghg_em_total + harv_ghg_em_total

cult_harv_ghg_em_ann_hectare $=$ cult_harv_ghg_em_lt_total / pat_land /

proj_period

\#Distillation

build ghg whole $=$ build area $*$ build unit ghg

build_ghg_total $=($ build_inst $*$ build_ghg_whole $) *$

distil.usg.rat

distil_unit_ghg $=($ distil_inst $*$ distil_unit_ghg $) *$

distil.usg.rat

elec_ghg_total $=($ elec $1+$ elec 2$) *$ proj_period $/ 2 *$ grid_emm_fac 
fw_ghg_total $=($ firewood $1+$ firewood 2$) *$ fw_ghg $*$ proj_period $/ 2$

distil ghg em lt total = build ghg total + distil_unit ghg +

elec_ghg total $+\mathrm{fw}$.ghg total

distil_ghg_em_ann_hectare $=$ distil_ghg_em_lt_total / pat_land / proj_period

pat_ghg_em_lt_total = cult_harv_ghg_em_lt_total + distil_ghg_em_lt_total

pat_ghg_em_lt_hectare $=$ pat_ghg_em_lt_total / pat_land

pat_ghg_em_ann_total $=$ pat_ghg_em_lt_total $/$ proj_period

pat_ghg_em_ann_hectare = pat_ghg_em_ann_total / pat_land

\# 4. PCH Model outputs: Economic

land_lease_total $=$ land_lease_ha $*$ proj_period $*$ land

seed_cost $=$ seedling $* \overline{\text { plants }}{ }^{*}$ surv_rate_recip

cost_achem $1=\mathrm{N} 1 * \mathrm{~N} \_$price $+\mathrm{P} 1 * \mathrm{P} \_$price $+\mathrm{K} 1 * \mathrm{~K} \_$price + manu $1 *$ manu $\_$price

cost_achem $2=\mathrm{N} 2 * \mathrm{~N} \_$price $+\mathrm{P} 2 * \mathrm{P} \_$price $+\mathrm{K} 2 * \mathrm{~K} \_$price + manu $2 *$ manu_price

diesel_cost $1=($ dies_f2f1 + dies_f2d1 $) *$ diesel_price

diesel_cost $2=($ dies_f2f2 + dies_f2d 2$) *$ diesel_price

cult_labor $=$ people_cult $*$ land $*$ salary_cult $*$ year

$\mathrm{fw} \_$cost $1=$ firewood $1 * \mathrm{fw} \_$price

$\mathrm{fw} \_$cost $2=$ firewood $2 * \mathrm{fw} \_$price

elec_cost $=$ mo_elec_cost * year \#assumes the distillation facility is run year-round, \#even before the maturity of the patchouli plants by taking in distillation materials from other farms.

distil_labor $=$ people_distil * salary_distil $*$ year

oil_rev1 $=$ oil_yield $1 *$ oil_price

oil_rev2 $=$ oil_yield $2 *$ oil price

labor_total $=$ cult_labor + distil_labor

ylb_profit_ann $=y l b \_p r o f i t * y l b \_h a r v e s t s *$ mai_land

comm_distil_rev1 $=$ comm_distillation $1 *$ comm_distil_price

comm_distil_rev $2=$ comm_distillation $2 *$ comm_distil_price

\# 5. PV Net present value at the end of the project period

PV_lg_inflow $<-$ c(rep(ann_fit_grid_total,proj_period) $)$

PV_lg_outflow $<-$ c(rep(ann_op_total,proj_period) $)$

cf_PV_lg $<-$ PV_lg_inflow - PV_lg_outflow

cf_PV_lg_tx $<-$ cf_PV_lg * tax_rate

NPV_PV_lg <- NPV (grid_tied_invest_total,cf_PV_lg_tx,years,disc_rate,plot=FALSE)

\# 5. $\overline{\mathrm{PC}} \overline{\mathrm{N}}$ Net present value at the end of the project period

pch invest $=$ land lease total + build $*$ distil.usg.rat +

distil_unit * distil.usg.rat + other_ini_inv + seed_cost

pch_inflow_a $=$ rep $\left(\mathrm{c}\left(\mathrm{oil} \_\right.\right.$rev1 + ylb_profit_ann,

oil_rev2 + ylb_profit_ann),proj_period/2)

pch_outflow_a $=$ rep $\left(\mathrm{c}\left(\operatorname{cost} \_a c h e m 1+\right.\right.$ fw_cost $1+$ diesel_cost1+labor_total+elec_cost,

cost_achem2+fw_cost $2+$ diesel_cost2+labor_total+elec_cost),proj_period/2) 
pch_outflow_b $=\mathrm{c}(0,0,0,0,0$, reinv, $0,0,0,0$, reinv+build $*$ distil.usg.rat + distil_unit * distil.usg.rat, $0,0,0,0$,reinv, $0,0,0,0$, reinv+build * distil.usg.rat + distil_unit $*$ distil.usg.rat ,0,0,0,0,reinv, $0,0,0,0)$

pch_outflow_30 = pch_outflow_a + pch_outflow_b

pch_cf_rep $=$ pch_inflow_a - pch_outflow_30

pch_cf_rep_tx $=\overline{\text { pch_cf_rep } * \text { tax_rate }}$

$\mathrm{NPV} \_\overline{p c h} \_\overline{l g} \_$rep $=\overline{\mathrm{N}} \mathrm{PV}(\mathrm{pch}$ invest,pch_cf_rep_tx,years,disc_rate,plot=FALSE)

\# 6. Summation of cash flows and net present value

col_invest $=$ pch_invest + grid_tied_invest_total

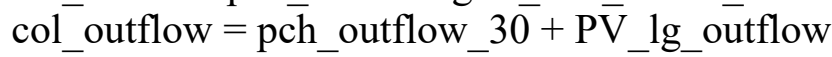

col ${ }_{\text {inflow }}=$ pch inflow a + PV 19 inflow

col_cf tx $=($ col_inflow - col_outflow $) *$ tax_rate

$\mathrm{NPV}$ _col_lg $<-\overline{\mathrm{N}} \mathrm{PV}\left(\mathrm{col} \_\right.$invest,col_cf_tx,years,disc_rate,plot=FALSE)

\# 7. Co-location specific

colo_en_input_ann_hectare <-pat_en_input_ann_hectare + pv_en_input_ann_hectare colo_en_output_ann_hectare $<-$ pv_en_output_ann_hectare

colo_ghg_em_ann_hectare $<-$ pat_ghg_em_ann_hectare + pv_ghg_ann_hectare

colo_dies_offset_ann_hectare $<-$ pv_dies_offset_ann_hectare

colo_grid_offset_ann_hectare $<-$ pv_grid_offset_ann_hectare

return(c(avg_oil_ann_hectare, colo_en_input_ann_hectare, colo_en_output_ann_hectare, colo_ghg_em_ann_hectare, colo_dies_offset_ann_hectare, colo_grid_offset_ann_hectare,

\} NPV_col_- $1 g$ ))

run $=10000$

colsummary $<$ - matrix $($ data $=$ NA, nrow $=$ run, ncol $=7$ )

for (i in 1:run) \{

plants <- rtriangle $(1,15000 *$ colo_plants, $25000 *$ colo_plants $)$

mat $<$ - rtriangle $(1,6,8)$

fresh_harv $<$ - rtriangle $(1,0.75,0.83)$

distil_cap $<$-rtriangle $(1,200,400,250)$

fw_distil $<$-rtriangle $(1,100,134,117)$

fw_en_cont $<$ - rtriangle $(1,2.043,4.086)$

fw_ghg $<$ - rtriangle $(1,11.70,23.41)$

colo_yield $<$-rtriangle $(1,1,1)$

oil_eff $<$-rtriangle $(1,0.025,0.03)$

oil_price $<$-rtriangle $(1,486000,764000)$

panels $<$ - rtriangle $(1,2500 *$ colo_panels, $3500 *$ colo_panels $)$

eff_PV $<$ - rtriangle $(1,0.14,0.16)$

pr $\overline{<}$-rtriangle $(1,0.749,0.767)$

avg_ann_irr $<$ - rtriangle $(1,1752,1898)$

fit_grid $\overline{<}$-rtriangle $(1,1750,2250)$

inst_price $<$-rtriangle $(1,25000,30000)$ 
colsummary[i,]<- colocated(plants,mat,fresh_harv,distil_cap,fw_distil, fw_en_cont,fw_ghg,colo_yield,oil_eff,oil_price,panels, \} eff_PV,pr,avg_ann_irr,fit_grid,inst_price)

write.csv(colsummary,'colsummary.csv') 